UNIVERSIDADE DE SÃO PAULO

FACULDADE DE FILOSOFIA, LETRAS E CIÊNCIAS HUMANAS

DEPARTAMENTO DE LETRAS CLÁSSICAS E VERNÁCULAS

PROGRAMA DE PÓS-GRADUAÇÃO EM FILOLOGIA E LÍNGUA PORTUGUESA

Jaqueline Massagardi Mendes

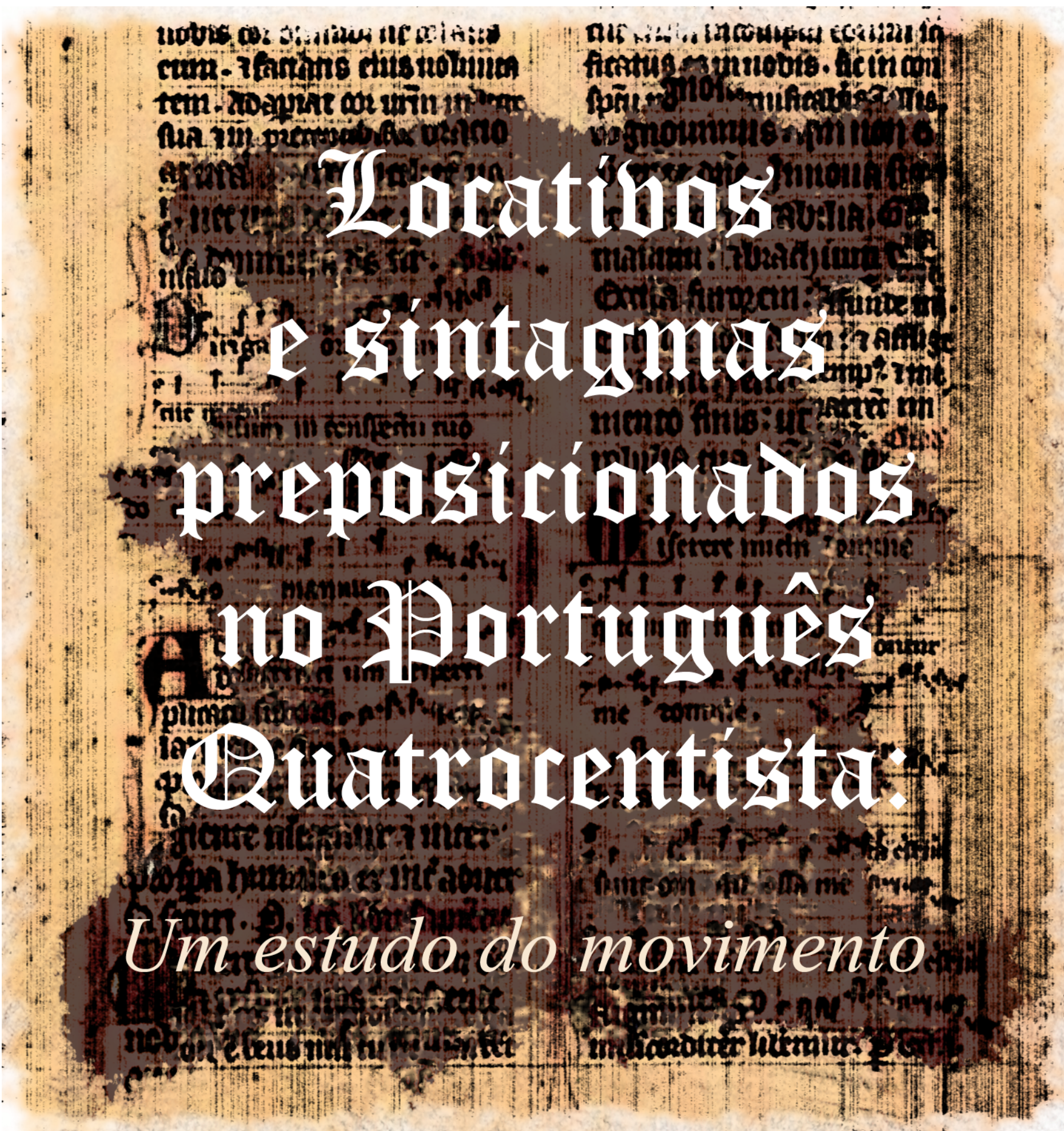

São Paulo 
UNIVERSIDADE DE SÃO PAULO

FACULDADE DE FILOSOFIA, LETRAS E CIÊNCIAS HUMANAS

DEPARTAMENTO DE LETRAS CLÁSSICAS E VERNÁCULAS

PROGRAMA DE PÓS-GRADUAÇÃO EM FILOLOGIA E LÍNGUA PORTUGUESA

Locativos e Sintagmas Preposicionados no Português Quatrocentista: um estudo do movimento

Jaqueline Massagardi Mendes

Tese apresentada ao Programa de PósGraduação em Filologia e Língua Portuguesa do Departamento de Letras Clássicas e Vernáculas da Faculdade de Filosofia, Letras e Ciências Humanas da Universidade de São Paulo, para a obtenção do título de Doutor em Letras.

Área de Concentração: História da Língua Portuguesa

Orientador: Profa.Dra. Marilza de Oliveira

- São Paulo - 
Autorizo a reprodução e divulgação total ou parcial deste trabalho, por qualquer meio convencional ou eletrônico, para fins de estudo e pesquisa, desde que citada a fonte.

Catalogação da Publicação

Elaborada com base no Vocabulário Controlado do SIBI/USP

(UNIVERSIDADE DE SãO PAULO, 2006)

Massagardi Mendes, Jaqueline.

Locativos e PPs no português quatrocentista: um estudo do movimento/

Jaqueline Massagardi Mendes; orientadora: Marilza de Oliveira. - São Paulo, 2009. $179 \mathrm{f}$.

Tese (Doutorado) - Universidade de São Paulo

1. Língua Portuguesa. 2. Lingüística Histórica. 3. Gramática. 4. Sintaxe- Sintaxe Formal. 5. Variação e mudança lingüística. I. Oliveira, Marilza de. II. Universidade de São Paulo. Faculdade de Filosofia Letras e Ciências Humanas. III. Título.

Título em inglês: Locatives and PPs in 15th century Portuguese Language: a movement study.

Palavras-chave em ingles: 1. Portuguese Language. 2. Historical Linguistics. 3.

Grammar. 4. Sintaxe- formal sintax. 5. Linguistic changes. 


\section{FOLHA DE APROVAÇÃO}

Jaqueline Massagardi Mendes

Locativos e Sintagmas Preposicionados no Português Quatrocentista: Um Estudo do Movimento

Tese apresentada ao Programa de Filologia e Língua Portuguesa do Departamento de Letras Clássicas e Vernáculas da Faculdade de Filosofia, Letras e Ciências Humanas da Universidade de São Paulo, para obtenção do título de Doutor em Língua Portuguesa, sob orientação da Profa. Dra. Marilza de Oliveira

Aprovado em: 15 de Junho de 2009

\section{Banca Examinadora}

Prof.Dr. Instituição

Julgamento Assinatura

Prof.Dr. Instituição

Julgamento Assinatura

Prof.Dr. Instituição Assinatura 
Prof.Dr. Instituição

Julgamento Assinatura

Prof.Dr. Instituição Assinatura 
Dedico este trabalho aо теи querido Deus,

Detentor de Glória, Majestade e Sabedoria.

Aquele que me sonda e me conhece desde

Que meu corpo era ainda informe...

Sem sua graça e amor

eu nada seria, nada faria... 


\section{AGRADECIMENTOS}

Agradeço, nesta ocasião, aqueles que foram diretamente importantes para este trabalho:

Devo agradecer especialmente à minha orientadora Profa.Dra.Marilza de Oliveira, cuja atenção voltada à esta pesquisa deve-se ressaltar. Foi ela quem me adotou desde a iniciação científica, e fez nascer dentro de mim a intuição investigativa. (Marilza, muito obrigada por ter acreditado em mim e neste trabalho! Sua opinião sempre foi crucial para que eu pudesse continuar...)

Às Profas.Dras. Ilza Ribeiro e Maria Clara Paixão de Souza, integrantes de minha Banca de Qualificação, a quem devo meu respeito e profunda gratidão. Suas críticas e sugestões tornaram este trabalho melhor.

Com muito carinho, agradeço a querida amiga Andrea Colsato, que por afinidade de área e projetos, lançou-se amistosamente à leitura de uma das versões deste texto. Esteve presente nos meus bons e maus momentos.

Serei sempre grata aos meus professores de Sintaxe, Sociolingüística e Lingüística Histórica da USP, Profs.Drs. Maria Aparecida Torres, Ângela Rodrigues, Ataliba Castilho e Marilza de Oliveira, aos quais devo minha paixão pela história da língua.

Aos amigos de pós-graduação da USP: Arnaldo, Hélcius, Hosana, que mesmo sem saber, foram importantes por acompanhar minha jornada. À Deize que gentilmente ensinou-me a operar o Goldvarb, programa cuja eficiência todo (sócio)lingüista deve reconhecer.

À Vanessa Bertuzzi, pela revisão do abstract.

Agradeço também aos professores da Unicamp que com maestria complementaram minha formação: Profs. Drs. Mary Kato, Ruth Lopes, Charlotte Galves e Juanito Avelar. E também aos amigos que fiz neste lugar: Carlos Felipe, Sabrina, Vivian, Lilian, Paulo, Pablo, Alyne, 
Elis, Manoela, Marcos, Fábio, Juliano, Gustavo ...nossas conversas sobre sintaxe e sobre qualquer coisa, tornaram tudo mais prazeroso.

Reservo o espaço que se segue, para honrar as pessoas sem as quais eu não conseguiria chegar a lugar algum...

Serei sempre grata ao meu amado Ricky, que sempre está ao meu lado, e sempre me entende, e me espera com um sorriso restaurador.

À minha pequena Rachel, presente que o Pai Celestial concedeu, e que nasceu no meio desta pesquisa. Um dia entenderá o quanto seus olhinhos cheios de alegria me fizeram seguir em frente. Entre mamadas e chorinhos esta tese foi se fazendo.

À toda minha famíla, que a cada dia ofereceu lugar seguro e abrigo... Aos meus queridos pais, que sempre foram os maiores incentivadores de meu crescimento pessoal e acadêmico, mas acima de tudo se preocuparam com a minha felicidade. Muito obrigada pelos incontáveis dias que cuidaram de minha filha para que eu pudesse desenvolver esta tese. Aos meus amados Rodrigo, Karina, e Rafaela, minha sobrinha...meus sogros e meu cunhado...obrigada por terem sido tão companheiros...

Ao tio Geraldo Massagardi, que durante noites e madrugadas, apresentou-me a Deus... Minhas avós Maria Ignez, Terezinha e Margarida...que têm resistido às forças do tempo e da saúde para me verem chegar mais alto. 
Agradeço particularmente à CAPES, cujo amparo financeiro foi imprescindível para a execução dessa pesquisa. 


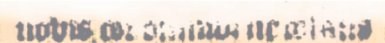
ctum. Tomono ctits trohitio

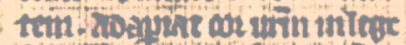

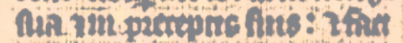
aspacult. coundiar mamo nu utE

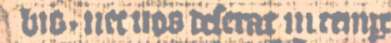
milo wiming os the 64 (x)

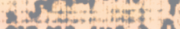

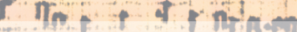

Com tudo, estes mesmos defeitos são agora interessantes para nos dar huma Idea do sabere
do gosto daquelle século, e das
das frazes podem os estudiosos
da nossa língua tirar informa-
o do passado e algum proveito
para o futuro. nos dar huma Idea do saber
do gosto daquelle século, e das
uas frazes podem os estudiosos
da nossa língua tirar informa-
âo do passado e algum proveito
para o futuro. nos dar huma Idea do saber e
do gosto daquelle século, edas
suas frazes podem os estudiosos
da nossa língua tirar informa-
ção do passado e algum proveito
para o futuro. nos dar huma Idea do saber e
do gosto daquelle século, e das
suas frazes podem os estudiosos
da nossa língua tirar informa-
ção do passado e algum proveito
para o futuro. nos dar huma Idea do saber e
do gosto daquelle século, e das
suas frazes podem os estudiosos
da nossa língua tirar informa-
ção do passado e algum proveito
para o futuro. nos dar huma ldea do sabere
do gosto daquelle século, e das
suas frazes podem os estudiosos
da nossa lúngua tirar informa-
çäo do passado e algum proveito nos dar huma Idea do saber
do gosto daquelle século, e das
suas frazes podem os estudiosos
da nossa língua tirar informa-
çấ do passado e algum proveito

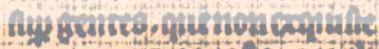
this the tos wormetion Monction huremint

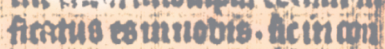

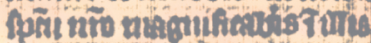
It oggiofatit se fla pives

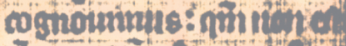
Prute one. Jntontit

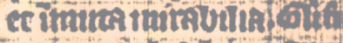

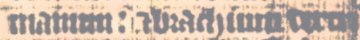

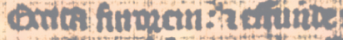

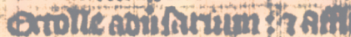

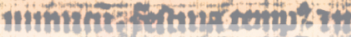

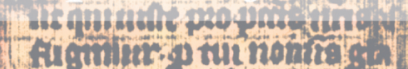

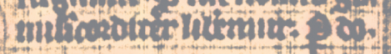

(Corrêa da Serra versando sobre "defeitos" de uma retórica "agreste", em Introducção às Chronicas de Gomes Eannes de Zurara, 1792) 


\section{RESUMO}

MASSAGARDI MENDES, Jaqueline. Locativos e sintagmas preposicionados no português quatrocentista: um estudo do movimento. 2009. 189 f. Tese de DoutoradoFaculdade de Filosofia, Letras e Ciências Humanas, Universidade de São Paulo. São Paulo:2009.

Nesta tese estudamos o movimento de sintagmas preposicionados (PPs), pronomes locativos (Locs) e pronomes locativos preposicionados (LocPs) em estruturas encaixadas do português quatrocentista, admitindo que esse período acomode variações que apontam para uma competição de gramáticas na linha de Kroch (1989, 1994, 2003).

Assumimos com Martins (1994), Muidine (2000) e Moraes de Castilho (2005), que os pronomes locativos $h i$ e ende tenham coexistido com os PPs, mas foram suplantados por estes últimos a partir do séc.XV. Tomando-se como corpus representativo do português quatrocentista a Crônica do Conde Dom Pedro de Menezes de Zurara, de fato atestamos PPs convivendo com pronomes locativos nos mesmos contextos sintáticos e inclusive os redobrando. As estruturas de redobro de um locativo por um PP mostraram-se relevantes por indicar a especialização das posições desses elementos.

Fazemos uso de duas linhas teóricas, conforme proposta de Kato e Tarallo (1989): um modelo mais formal como a Teoria de Princípios e Parâmetros (Chomsky, 1986) e um de cunho variacionista como a Sociolinguística Laboviana,

Para uma análise descritiva dos dados, seguimos a metodologia da Sociolingüística Quantitativa, pontuando fatores lingüísticos condicionadores da posição desses constituintes. 
De modo geral, os cálculos estatísticos registraram altos índices de movimento dos locativos, por um lado, mas baixos índices de movimento dos PPs, por outro. Já os LocPs equilibraram movimento e posição canônica. Outros fatores como função sintática e tipo de oração incidiram no movimento de PPs e Locs, sobretudo.

A análise interpretativa dos resultados se deu sob uma perspectiva gerativista, à luz da Teoria de Princípios e Parâmetros (Chomsky, 1981,1986). Tomando-se o clítico e o sujeito como marcadores de fronteira, conforme propostas de Martins (1994) e Belletti (2002), foi possível vislumbrar quatro posições de ancoragem para os Locs e PPs, que se distribuíram ao longo da estrutura sentencial.

Ficou, por fim, evidente, que o movimento de Locs, PPs e LocPs é um caso de competição de gramáticas no português quatrocentista, que acompanha algumas mudanças que desembocam na constituição do português brasileiro.

Palavras-chave: sintagmas preposicionados, pronomes locativos, movimento de constituintes, estrutura sentencial e topicalização. 


\section{ABSTRACT}

MASSAGARDI MENDES, Jaqueline. Locatives and PPs in $\mathbf{1 5}^{\text {th }}$ century Portuguese Language: A Movement Research. 2009. 189 pages. PhD Thesis - Faculdade de Filosofia, Letras e Ciências Humanas, Universidade de São Paulo. São Paulo:2009.

This research analyses the movement of prepositioned phrases (PPs), locative pronouns (Locs) and prepositioned locative pronouns (LocPs) in embedding structures of the $15^{\text {th }}$ century Portuguese language, admitting that this period has variations which point to a grammar competition in Kroch's $(1989,1994,2003)$ framework.

According to Martins (1994), Muidine (2000) and Moraes de Castilho (2005), latin locative pronouns $h i$ and ende, and PPs had coexisted in Portuguese until the $15^{\text {th }}$ century, when PPs supplanted the usage of locative pronouns. Indeed, taking the Dom Pedro de Menezes Cronic of Zurara (Brocardo, 1997) as the $15^{\text {th }}$ century Portuguese representative corpus, we have found PPs coexisting with locatives in the same syntactic contexts, redoubling them as well. The redoubling structures have turned out to be relevant for indicating the specialization of the positions of these elements.

Taking Kato and Tarallo (1989) into consideration, two frameworks are used: one formal model like the theory of Principles and Parameters, and abnother variational like Labov Sociolinguistics.

The Quantitative Sociolinguistic methodology is considered for a descriptive analysis of the data, indicating linguistic facts that could affect the position of PPs and locative pronouns. Statistics have registered high percentages regarding the movement of locative 
pronouns on one hand, but low percentages of PPs movement on the other. LocPs registered similar numbers for movement and for no movement. Other factors such as syntactic function and kind of sentence influenced the movement of PPs and Locs..

The interpretative analysis of the results has happened in the framework of Generative Syntax, considering the Principles and Parameters Theory (Chomsky 1981, 1986). Taking clitics and subject as frontier demarcators, as stated by Martins (1994) and Belletti (2002), it has been possible to verify four positions to host Locs and PPs, all distributed along the sentential structure.

In conclusion, it has been evident that PP and locative movement is a grammar competition case in the 15 th century Portuguese language and it will accompany some changes which will arise in the Brazilian Portuguese language.

Keywords: prepositioned phrases, locative pronouns, movement of constituents, sentential structure and topicalization. 


\section{ÍNDICE DE TABELAS}

\section{Capítulo 3 - MOVIMENTO DOS LOCATIVOS, PPs E LOCPs}

Tabela 1:Posição do clítico nas subordinadas finitas no PM. 114

Tabela 2: A interpolação da negação. 115

\section{Capítulo 4 - MOVIMENTO DOS LOCATIVOS, PPs E LOCPs}

\subsection{Comparando pronomes locativos, PPs, e LocPs}

Tabela 1: Peso do complemento da preposição x Posição do PP 127

Tabela 2: Função Sintática PP/Loc/LocP x Movimento 128

Tabela 3: Categoria que Seleciona PP/Loc/LocP x Movimento.

Tabela 4: Posição do sujeito em relação ao verbo x Movimento PP/Loc/LocP

\subsection{Comparando pronomes locativos e locativos preposicionados}

Tabela 5: Tipo de Locativo x Movimento. 136

Tabela 6: Referencialidade do pronome x Movimento 140

Tabela 7: Anaforicidade x Tipo de pronome locativo. 141

\subsection{Comparando PPs e Locativos Preposicionados}

Tabela 8: Tipo de preposição x Movimento PP/LocP 143

Tabela 9: Tipo de preposição do LocP x Tipo de locativo.

Tabela 10: Caso x Movimento de PPs e LocPs

Tabela 11: Caso x Tipo de preposição do PPs. 148

Tabela 12: Caso x Tipo de preposição do LocP 149

Tabela 13: Caso do LocP x Tipo de locativo 149 
Tabela 14: Caso x anaforicidade do LocP.

\section{Anexos do capítulo 4}

Anexo 1: Posição dos Locativos, PPs, e LocPs.

Anexo 2: Tipo de sentença x Movimento de PPs/Locs/LoPs......

Anexo 3: Tipo de preposição X percentual de movimento de PP. 


\title{
ÍNDICE DE QUADROS
}

\section{Capítulo 3.}

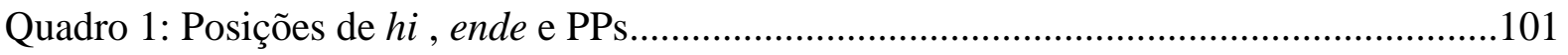

Quadro 2: Etapas de mudança do locativo hi e seu redobro, o PP........................................109

\section{ÍNDICE DE GRÁFICOS}

\subsection{Comparando Pronomes Locativos, PPs e Locativos Preposicionados}

Gráfico 1: Percentual de movimento dos Locativos, PPs, e LocPs......................................125

Gráfico 2: Tipo de sentença x Percentual de movimento de PPs/Locs/LocPs........................133

Gráfico 3: Tipo de Preposição x Percentual de movimento de PP.........................................144

\section{LISTA DE SÍMBOLOS}

\author{
*agramaticalidade \\ ? $\quad$ gramaticalidade duvidosa \\ $\Theta \quad$ Papel Temático
}




\section{LISTA DE SIGLAS E ABREVIATURAS}

Adv

AdvP

AgrP

AgrOP

AgrSP

ANAF

AP

ASP

$\mathrm{BP}$

C/Comp

$\mathrm{Cl}$

$\mathrm{CP}$

CPM

DP

DS

ECP

EPP

expl.

F, Foco, Foc

FP, FocP, FocoP

GU

GT

I

IE

IL

IP

Locs

LocPs

LF

$\mathrm{N}$

NEG
Advérbio

Adverb Phrase $=$ Sintagma Adverbial

Agreement Phrase $=$ Sintagma de Concordância

Agreement Object Phrase $=$ Sintagma de Concordância do Objeto

Agreement Subject Phrase $=$ Sintagma de Concordância do Sujeito

Anafórico, anaforicidade

Adjunto Frásico

Aspect $=$ Aspecto

Brazilian Portuguese $=$ Português Brasileiro

Complementizador

clítico

Complementizer Phrase $=$ Sintagma Complementizador

Crônica do Conde D.Pedro de Menezes

Determiner Phrase $=$ Sintagma Determinante

Deep Strutucture $=$ Estrutura Profunda

Empty Category Principle $=$ Princípio da Categoria Vazia

Extend Projection Principle $=$ Princípio da Projeção Estendido

Expletivo

Focus $=$ Foco

Focus Phrase $=$ Sintagma de Foco

Gramática Universal

Gramática Tradicional

Inflection $=$ Flexão

Inversão Estilística

Inversão Livre

Inflection Prase $=$ Sintagma Flexional

Pronomes Locativos

Pronomes Locativos Preposicionados

Logical Form $=$ Forma Lógica

Noum $=$ Nome

Negative $=$ negação 


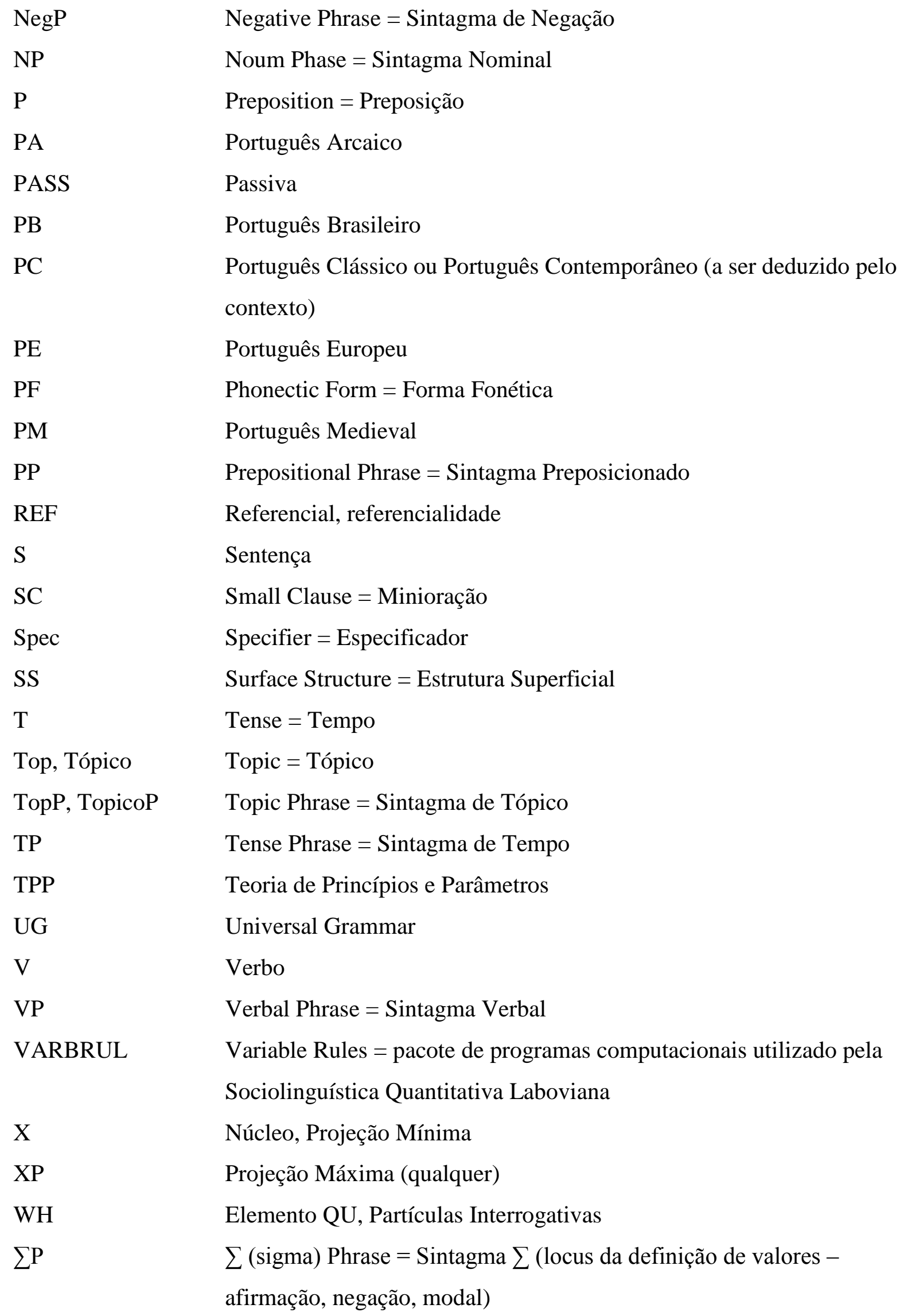




\section{SUMÁRIO}

RESUMO

ABSTRACT

Índice de tabelas.

Índice de quadros

Índice de gráficos

Lista de símbolos.

Lista de siglas e abreviaturas. 16

INTRODUÇÃO. .22

\section{CAPÍTULO 1. METODOLOGIA}

Introdução .34

1.1. Corpus e datação. .35

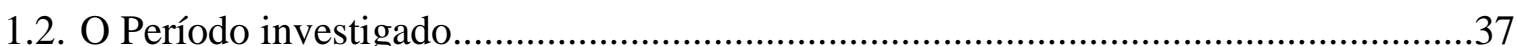

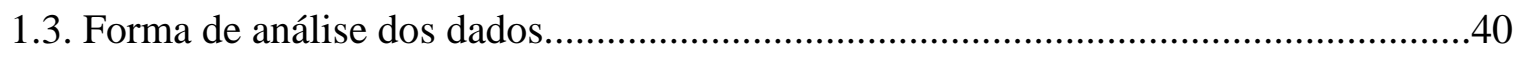

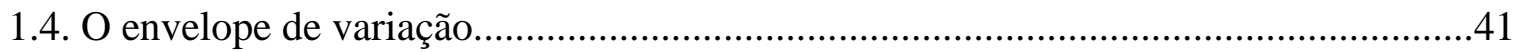

1.4.1 Grupos de fatores condicionadores do movimento de PPs, Locs e LocPs......41

1.4.2 Grupos de fatores comparativos do movimento de Locs e LocPs. .45 
1.4.3. Grupo de fatores comparativos do movimento de PPs e LocPs .47

1.5. As análises qualitativas. .47

1.6. Considerações finais do capítulo. .50

\section{CAPÍTULO 2. PRESSUPOSTOS TEÓRICOS}

Introdução. .53

2.1 A Teoria de Princípios e Parâmetros. .54

2.1.1 Variação e mudança: diferentes concepções. .56

2.2. As Categorias funcionais .59

2.3. A interpolação e o especificador múltiplo de AgrS .68

2.4. A categoria sigma e os clíticos. .73

2.5. A periferia esquerda e o desmembramento de CP. .76

2.6. Tópico e Foco de IP: uma proposta de Belletti(2002). . .80

2.7 Considerações finais do capítulo. .84

\section{CAPÍTULO 3. MOVIMENTO DO LOC E DO PP: Revisão da Literatura}

3.1. Movimento de PPs nas sentenças encaixadas do séc.XIX. .89

3.2. Pronomes hi e ende: classificação tripartida pronominal e posição. .92

3.3. Locativos e PPs no processo de redobramento sintático do português medieval..102

3.4. A interpolação de constituintes na história do português 
3.4.2 Do Português Medieval para o Português Clássico: a mudança dos constituintes interpoláveis.

\section{CAPÍTULO 4. MOVIMENTO DOS LOCATIVOS, PPS E LOCPS:}

\section{Fatores Condicionadores}

4.1. O redobro PP-Loc ou Loc-PP

4.2. Comparando pronomes locativos, PPs, e locativos preposicionados

4.3. Comparando pronomes locativos e locativos preposicionados

4.4. Comparando PPs e locativos preposicionados

4.4.1. O núcleo de PP e de LocP na incidência do movimento.

4.4.2 Caso desempenhado pela preposição e movimento de PPs e LocPs.....145

4.5 Considerações finais do capítulo

Anexos.

\section{CAPÍTUlO 5. O LUGAR DE POUSO DE LEMENTOS MOVIDOS:}

\section{Reposicionando os elementos na estrutura sentencial}

5.1. O clítico como evidência do lugar de pouso

5.2. Identificando os hospedeiros dos Locs/PPs movidos. 
5.3. Considerações finais do capítulo. .172

CONCLUSÃO 175

REFERÊNCIAS BIBLIOGRÁFICAS 


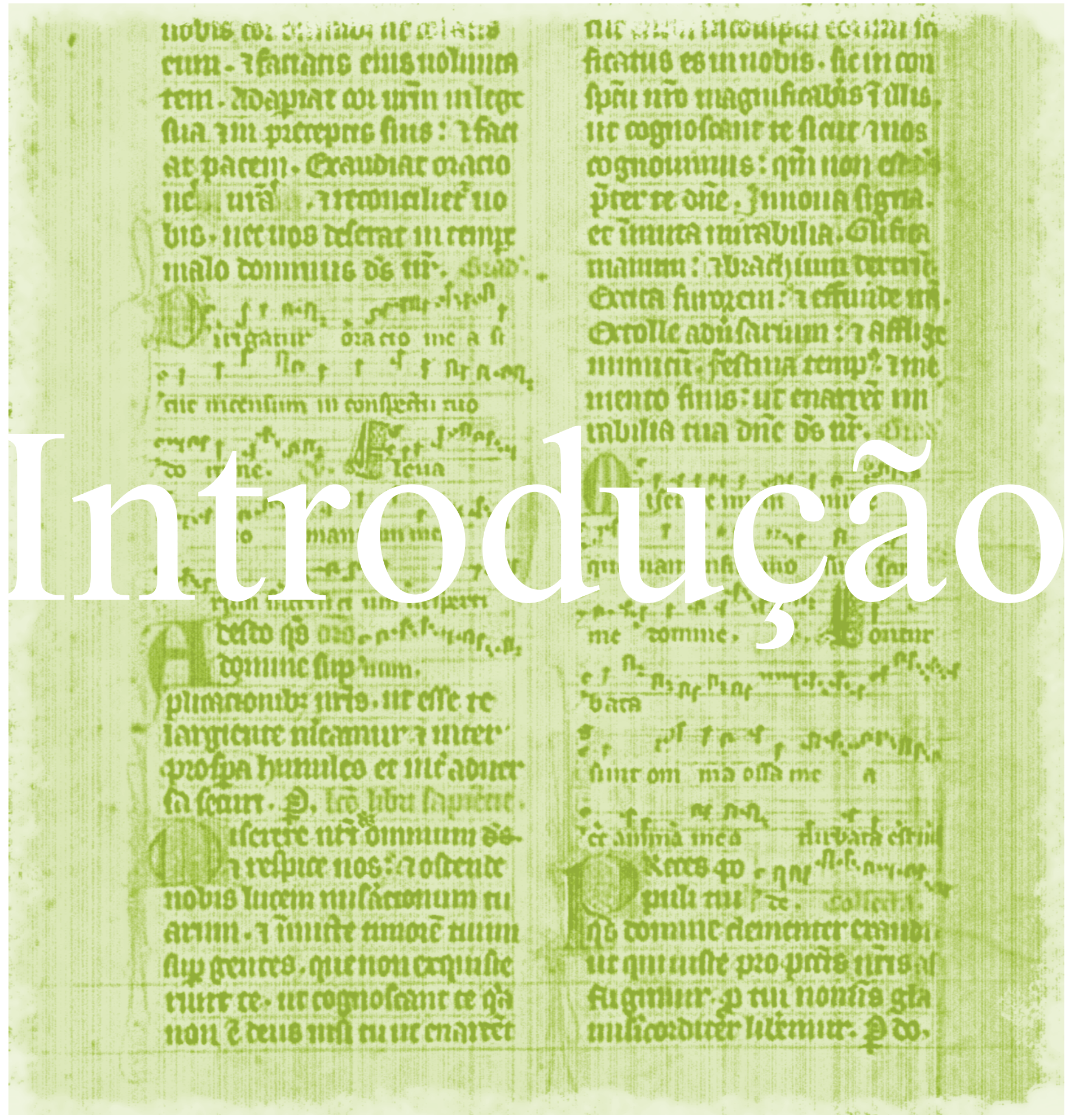




\section{INTRODUÇÃO}

ropomos, com este trabalho, investigar o movimento dos pronomes
locativos, sintagmas preposicionados e locativos preposicionados
(doravante Locs, $\mathrm{PPs}^{1} \mathrm{e} \mathrm{LocPs}^{2}$ ) em sentenças encaixadas ${ }^{3}$ do português quatrocentista ${ }^{4}$.

Analisamos paralelamente PPs, Locs e LocPs já que pesquisas diacrônicas mostram que os PPs encabeçados pelas preposições em e de passaram a substituir pronomes locativos do tipo hi e ende por volta do séc.XV.

Em Massagardi Mendes (2004) havíamos estudado o movimento de PPs em estruturas encaixadas dos sécs.XIX-XXI. Tendo tomado como corpus o português brasileiro, verificamos que já no século XIX, os índices de movimento de PPs já não eram altos, e começavam a declinar bruscamente até o século atual. A tabela 1, abaixo, mostra numericamente o contraste de movimento de PPs no século XIX e XXI:

\footnotetext{
${ }^{1}$ Conforme a nomenclatura da corrente lingüística conhecida como Gramática Gerativa, a qual é adotada como amparo teórico desta pesquisa, a sigla PP (prepositioned phrase) corresponde à projeção do sintagma preposicionado.

${ }^{2}$ Não confundir a sigla LocP com a projeção máxima de Loc. Não entenda LocP como Loc Phrase, mas simplesmente como a abreviatura do pronome locativo preposicionado. A análise dos LocPs, diferentemente dos PPs e Locs, deu-se também no contexto de sentenças independentes dada a raridade dos dados.

${ }^{3}$ São conhecidas por sentenças encaixadas ou dependentes as orações subordinadas da Gramática Tradicional. Estas sentenças opõem-se às sentenças principais ou independentes.

${ }^{4}$ De acordo com a tradição filológica, o português medieval se estende até meados do séc.XVI. Segue-se o português clássico até meados do séc.XIX. Observe-se que mediante a tradição, o português quatrocentista (séc.XV) estaria englobado no português medieval.
} 
Tabela 1: Posição dos PPs em dois momentos da história do Português: séc.XIX e séc.XXI

\begin{tabular}{|l|l|l|}
\hline $\begin{array}{l}\text { Período do } \\
\text { Português }\end{array}$ & $\begin{array}{l}\text { PPs } \\
\text { movidos }\end{array}$ & PPs in situ \\
\hline Século $X I X$ & $20 \%$ & $80 \%$ \\
\hline Século XXI & $9,3 \%$ & $91,7 \%$ \\
\hline
\end{tabular}

Observe-se que o movimento de PPs, desde o século XIX, apresentava-se pouco produtivo, e acabou por chegar à atualidade apenas como um fenômeno residual. A pergunta que decorreu daí foi: haveria taxas maiores de movimento de PPs em períodos anteriores, ou o movimento de PPs em estruturas encaixadas sempre se apresentou baixo?

Tendo isso em vista, passamos a investigar paralelamente o movimento de pronomes locativos e PPs no português quatrocentista (do século XV), já que os primeiros foram substituídos por esses últimos justamente a partir desse período.

Os PPs, Locs e LocPs escolhidos para análise são de natureza geral. Foram englobados na análise tanto PPs/Locs/LocPs adjuntos e complementos verbais ou nominais, quanto PPs e LocPs portando qualquer função casual (função locativa/partitiva, dativa, genitiva, ou ablativa) ${ }^{5}$.

Para dar conta de explicar o fenômeno, acomodamos os dados dentro do arcabouço teórico da Sintaxe Gerativa em sua versão de Princípios e Parâmetros (Chomsky 1981,1986), sempre com a preocupação de observar e descrever a variação

\footnotetext{
${ }^{5}$ As análises específicas de PPs com função locativa e partitiva, que correspondem diretamente aos pronomes $h i$ e ende serão apresentadas no capítulo 4, que traz a análise qualitativa e quantitativa do movimento de Locs, PPs, e LocPs.
} 
da posição e o comportamento sintático desses PPs/Locs/LocPs. Buscamos identificar, sobretudo, posições diferentes daquelas em que esses sintagmas são gerados.

Os Locs/PPs/LocPs são gerados canonicamente dentro do $\mathrm{VP}^{6}$ (sintagma verbal), imediatamente após o constituinte que os seleciona, conforme podemos observar nos exemplos de PPs (1, 2), Loc (3) e LocP (4), abaixo:

(1) o qual vos pede por merçee que vos syrvais delle $(\mathrm{CPM} / \mathrm{p} .199 / 1599)^{7}$

(2) que sabem a fraqueza dos mouros (CPM/ p.212/1947)

(3) comsyderamdo que eu nom vos lexo aquy (CPM/p.206,1780)

(4) mamdou a allgũs escudeyros seus que se fossem pera laa (CPM/ p.482, 1 947)

Observe que em (1), o PP coloca-se na posição pós-verbal, e em (2) na posição pós-nominal. Essas são as posições canônicas do Loc/PP/LocP, as quais também chamaremos de posição in situ.

Além da posição in situ, o PP/Loc/LocP pode ser encontrado em outras posições. Seguindo a estrutura frasal proposta por Martins (1994), em que se toma o clítico como fronteira, o PP/Loc/LocP pode aparecer entre C e clítico, ocupando a posição de foco/tópico/adjunto frasal, bem como pode aparecer entre clítico e verbo. (Abaixo, o PP também pode ser substituído por Locs e PPs).

$$
\text { C (PP1) clítico (PP2) Verbo }
$$

\footnotetext{
${ }^{6} \mathrm{Na}$ gramática gerativa dá-se o nome de VP (verbal phrase) à projeção do sintagma verbal.

${ }^{7}$ A sigla CPM refere-se à Crônica de D.Pedro de Menezes, séc.XV, que compõe nosso corpus de análise.
} 
Chamaremos PP1 de PP fronteado e PP2 de PP interpolado. Ambos resultam de movimento de constituintes para uma posição pré-verbal. Nem sempre, porém, é possível distinguir PP fronteado de interpolado, pois a distinção é norteada pela presença do clítico que nem sempre ocorre na estrutura sentencial.

Ainda que a posição do PP/Loc não tenha sido o foco de suas pesquisas, Martins (1994), Ribeiro (1995), estudando fenômenos ligados à sintaxe da ordem no Português Medieval, atestaram casos de fronteamento e de interpolação dos PPs e em alguns casos de Locs..

Martins (1994) atestou PPs fronteados e PPs interpolados no português medieval (5-7) e no português clássico (9-12). São exemplos de PPs fronteados (veja PPs em grifo e clíticos negritados):

(5) “que per esto lhe nõ valhã (Lx, 1440)".

(6) "E sse pela uẽntura vos algue enbargar (Lx, 1296)"

(7) "E sse pela uẽntura vos alguen a dicta u- $\widetilde{y}_{a}$ enbargar (Lx, 1296)

(8) "E sse pela uẽntura a vos assi nõ adubardes (Lx, 1305)"

(9) Entrando depois em casa de seu pai, nem a ela, nem a ele conhecia, polo diferente estado em que a deixara; e, como nesta mudança se lhe não aquietava o coração, foi-se com muita pressa aonde o tinha pôsto. (Lobo-XVI)

(10) Há-de ser animoso e liberal; o primeiro, por que nas matérias que tocarem a guerra, trégua e liga, ou confederação com o seu Príncipe, se não mostre por sua parte acanhado, tímido, nem pusilânimo. (Lobo-XVI)

(11) Para em Calais me não impedirem a saída, nem nas outras cidades até Paris me negarem a entrada por ir de lugar infecto, levo passaporte e 
recomendação do embaixador de França que está neste reino. (Vieira-cartasXVII)

Os PPs interpolados foram largamente registrados pela autora, conforme exemplificamos a seguir. Os PPs aparecem sublinhados, e os clíticos, em negrito:

(12) como se nelle contem (NO, 1513, ex.144, p.169)

(13) sem se por ello poder chamar fforcado (NO, 1513, ex.145, p.169)

(14) que se sobrello podeRja Recreçer (NO, 1514, ex.146, p.169)

(15) e ho que se dellas merecese pagar (NO, 1538, ex.150, p.170)

(16) que se por ela pasou (NO, 1545, ex.154, p.170)

(17) e como lhe de dereito pertencem (Lx, 1532, ex.158, p.170)

Além de o PP interpolado se apresentar como fenômeno mais freqüente numericamente do que o PP fronteado, o espectro de preposições usadas como núcleo do PP é bastante variado, ao contrário do caso de PP fronteado que, no português medieval, se restringe à preposição por.

Nos dados de Martins, encontramos ainda uma terceira posição para o PP movido. Trata-se da posição à direita do verbo flexionado, mas não na posição canônica, pois os elementos que os selecionam estão abaixo dos PPs. Como essa posição não tem sido objeto de estudo, não lhe foi atribuída nenhuma nomenclatura. Tendo em vista que se trata de elemento movido, mas não para posição alta na sentença, chamaremos os elementos que ocupam essa posição de "protelado" 8 . As sentenças abaixo exemplificam o PP "protelado", conforme grifos:

\footnotetext{
${ }^{8}$ A terminologia "protelado" é nossa. Embora as autoras tenham encontrado esta posição, não a estudaram especificamente, nem lhe atribuíram alguma denominação.
} 
(18) Que uos abrã deles mãão (NO, 1441, p.421)

(19) E que faça a eles entregar todalas herdades (NO, séc.XIII-XIV, p.154)

Ribeiro (1995), que também se dedicou ao estudo de amostras do português medieval, registrou constituintes fronteados, mas, contrariamente aos dados de Martins para o mesmo período, nucleados por diferentes tipos de preposição (20-21). Quanto à interpolação, assinalou a sua forte incidência em sentenças encaixadas, tendo encontrado todo tipo de constituinte nessa posição, inclusive PPs e locativos (22-29) ${ }^{9}$ :

(20) e deziam que em cada casa se colhiam xxx ou R pesoas (CPVC.F9.19-20)

(21) komo que ante se acabaria o dia que eu leixasse de contar o que... (DSG 1.1.29)

(22) e se se del alçar (FR.1.10.82r)

(23) aaquele queo da prima agasalhou (CPVC.F4v.9)

(24) seo hy ouuese (CPVC.F4v.5)

(25) ca o coraçon que se per muitos cuidados parte (DSG.1.8.56)

(26) non recebia embargo de nengüü que me de todo esto estorvasse (DSG.1.1.4)

(27) quando o por cousas grandes rogasse (DSG.1.23.12)

(28) per razon das cousas que se per eles poden entender (DSG.1.1.40)

(29) Ca o mal que lh'ende acaeceu (DSG.1.25.21)

\footnotetext{
${ }^{9}$ Namiut (2008), estudando a interpolação da negação em textos do Português Clássico, também registrou casos de PPs fronteados (1-3) e resíduos de PPs interpolados (4):

(1) pois perdi um Rei tão conhecido de meus serviços, e merecimentos, que por eles me fez honrado, rico, e grande em seu Reino. (Couto, 1542)

(2) que por outro nome se chamava de Caloa (Couto, 1542)

(3) que pêra isso se chamaram. (Couto, 1542)

(4) ...e entregando-lhe aquele Rei o dia que se dele despedio...(Couto 1542)
} 
Além da alta incidência, atestou a ocorrência de mais de um PP interpolado, o que pode sugerir que exista mais de uma posição disponível para abrigar elementos interpolados:

(30) a guarda que Deus ha daqueles que se en este mundo polo seu amor despreçaron (DSG.1.8.45)

Registrou também a presença de PPs protelados, elementos movidos que ocupam posições mais baixas ou "atrasadas":

(31) e sabendo que eram a ello negligentes (CDP.5.17)

(32) que nos ajudauam deles aacaretar lenha (CPVC.9v.8-9)

(33) per guisa que eu nom puide tomar d'ello conta assessegadamente (CDP.13.27 28)

Muidine (2000), estudando os pronomes locativos $h i$ e ende em textos do português medieval, aos quais atribuiu o caráter fraco, com base na proposta de Cardinaletti \& Starke (1999), tomou-os como elementos de marcação de fronteira ${ }^{10}$ e, com isso, identificou os seguintes casos de interpolação (nesse caso, os pronomes locativos hy aparecem em negrito,e o PP sublinhado):

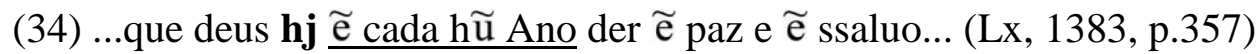

(35) ...os quaes seis mil reeaes a dita vendedor logo hy perante mim tabaliã (Lx, 1532, p.650)

\footnotetext{
${ }^{10}$ Ao contrário de Muidine, não tomaremos o pronome locativo fraco como elemento de fronteira entre os constituintes sentenciais.
} 
O exemplo (35), no entanto, faz parte de uma estrutura de redobramento sintático, pois "perante mim tabaliã" retoma e especifica o locativo hy, fenômeno atestado em dados do português medieval (Moraes Castilho 2005). Nos exemplos abaixo negritamos os locativos do tipo $h y / y / i$ e sublinhamos os PPs que os redobram:

(36) ...e a todolos outros que $\mathbf{y}$ en esse moesteyro a Deus seruẽ e seruirã .(XIII:1299 HPG 214: 3)

(37) E então o filho que andava i na nave ouvio aquela palavra que sa madre dissera. (XIII LVL 49”28)

(38) ... fora as donzelas que en presom jazem i (XIII SG 349: 26)

(39) ..e meadade de todo pam que $\mathbf{y}$ lauorardes na eyra

[XIV:1321 HGP 77:20]

Em (36) o redobro associado ${ }^{11}$ (locativo e PP estão contíguos) ocupa posição alta na sentença; em (37) o redobro associado ocupa posição in situ. Em (38-39) temse o redobro dissociado, sendo que em (38) o PP está em posição fronteada e o locativo in situ e em (39) observa-se exatamente o contrário. A autora propõe uma fase em que o redobro aparecia associado, uma segunda fase em que o redobro é dissociado e uma terceira em que o redobramento sintático deixa de existir.

Estas foram as pesquisas que serviram de ponto de partida para nossas investigações.

Apesar dos já inúmeros trabalhos que tratam da perda de movimento de constituintes no português medieval, como os de Martins (1994), Ribeiro (1995),

\footnotetext{
${ }^{11}$ A nomenclatura redobro associado é nossa. A autora chama esses redobros de estrutura original.
} 
Parcero (1999), Muidine (2000) e Moraes Castilho (2001), entre outros, a literatura ainda se ressente de uma análise descritiva que observe os fatores condicionantes do movimento de constituintes e que faça um tratamento paralelo entre locativos (preposicionados e não) e PPs, tendo em vista a ocorrência de redobramento sintático no português medieval.

Adotando a hipótese de que o Português Brasileiro é de base quatrocentista (Moraes Castilho, 2001), a presente pesquisa enfoca a posição dos PPs e dos pronomes locativos em um corpus específico: Crônica de D. Pedro de Meneses, do cronista Gomes Eanes Zurara, como texto representativo do século XV, que precedeu imediatamente o descobrimento do Brasil.

O nosso objetivo é, portanto, averiguar se estava consolidada a posição de PPs , Pronomes Locativos e Pronomes Locativos Preposicionados na estrutura sentencial do período quatrocentista do português. Procuraremos responder às seguintes questões:

i. Qual a incidência de redobro no corpus quatrocentista tomado para análise? ii. PPs , Locativos e Locativos Preposicionados distribuem-se de maneira semelhante na estrutura sentencial?

iii. O movimento de PPs, Locativos e Locativos Preposicionados é igualmente condicionado por fatores lingüísticos?

iv. Quais as posições de ancoragem disponíveis para os PPs, pronomes locativos, locativos preposicionados movidos?

Com base nos objetivos acima especificados, propomos as seguintes hipóteses que nortearão a análise dos PPs e dos Locativos: 
i. Assumimos com Galves, Paixão de Souza e Namiut (2006) que o corpus quatrocentista deixa transparecer variações interpretáveis como competição de gramáticas (Kroch 1989, 1994, 2001). O lugar de pouso para os PPs, Locativos e Locativos Preposicionados movidos seria mais um fenômeno lingüístico em variação apontando para a competição de gramáticas;

ii. Mudanças no sistema pronominal locativo (perda de ende e reanálise de $h i$, que passa de anafórico a dêitico) incidem na posição de PPs;

iii. Ao invés da fixação da posição dos pronomes, numa relação um-para-um entre posição e tipo morfológico de pronome (Cardinaletti \& Starke 1999), partimos da idéia de que o pronome locativo pode ocupar diferentes posições na estrutura sintática, a depender do traço de anaforicidade que carregam.

Esta tese está dividida assim:

Apresentamos, primeiramente esta introdução com justificativa, objetivos e hipóteses. No capítulo (1) revelamos a metodologia adotada para análise, e tratamos de assuntos que permeiam o tema, como escolha do corpus e período de investigação. Os pressupostos que serviram de base e arcabouço teórico para a pesquisa acham-se no capítulo (2); e no capítulo (3) fazemos uma revisão da bibliografia, trazendo análises que de algum modo trataram de Locs e PPs na história da língua portuguesa. Quanto aos capítulos de análises, estes foram organizados da seguinte maneira: o capítulo (4) trata dos fatores que condicionam o movimento de PPs, Locs e LocPs; e (5) trata estruturalmente o lugar de pouso desses constituintes. Por fim, tecemos algumas considerações conclusivas, seguidas da bibliografia. 


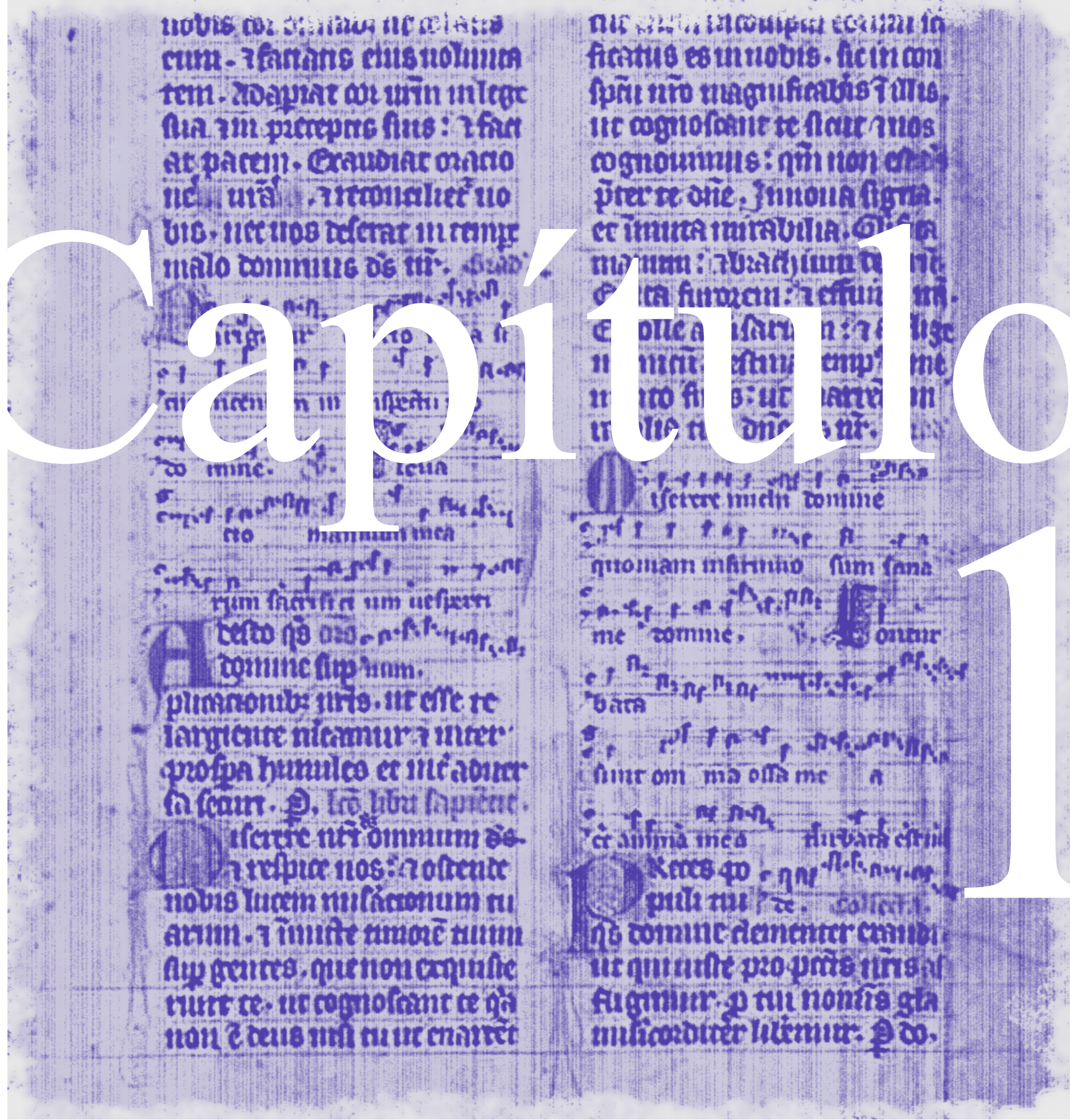




\section{METODOLOGIA}

\section{Introdução}

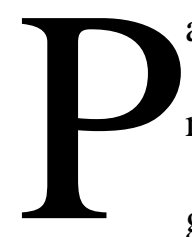
assamos à apresentação da metodologia aplicada à pesquisa. Partimos da união dos modelos da Teoria de Princípios e Parâmetros (Chomsky 1981, 1986), do gerativismo, e da Teoria da Variação e Mudança Lingüística, da sociolingüística laboviana (Weinreich, Labov \& Herzog, 1968; Labov, 1972, 1975, 1982), conforme proposta de Kato e Tarallo (1989) ${ }^{12}$. O primeiro para atribuir-lhes uma interpretação teórica, e o último para dar um tratamento quantitativo aos dados.

Três conjuntos de dados foram utilizados para a investigação. No primeiro, selecionamos sentenças com a presença de pronomes locativos ${ }^{13}$, no segundo, sentenças com PPs, e no terceiro conjunto de dados selecionamos sentenças com a presença de pronomes locativos preposicionados. Os dois primeiros foram analisados somente em contexto de sentenças encaixadas, e o terceiro abrangeu orações principais e encaixadas.

Para o estudo do lugar de pouso do elemento movido, realizamos uma análise qualitativa dos dados, em função de marcadores de fronteira (Martins 1994 e Belletti 2002).

\footnotetext{
${ }^{12}$ A união de dois modelos teóricos para gerar uma análise lingüística mais apurada foi inicialmente proposta por Kato e Tarallo (1989) e seus principais resultados podem ser conferidos em Kato e Roberts (1993).

${ }^{13}$ Incorporamos à pesquisa a análise de pronomes locativos (preposicionados ou não), já que estes concorrem com o uso de PPs, de acordo com as proposições de Muidine (2000) e Moraes de Castilho (2005).
} 
Situamos a pesquisa no âmbito do português quatrocentista. A seguir, faremos menção ao corpus (1.1) e período escolhido para o estudo do fenômeno (1.2). Na seção (1.3) explanamos a forma pela qual os dados foram analisados, e em (1.4) apresentamos o envelope de variação. As seções (1.5) e (1.6) mencionam as análises qualitativas e tecem as considerações finais, respectivamente.

\subsection{Corpus e datação}

Os dados foram todos extraídos da Crônica do Conde D.Pedro de Meneses ${ }^{14}$, de Gomes Eanes de Zurara. Trata-se da narrativa de fatos relacionados à conquista portuguesa da cidade de Ceuta, durante a capitania de D. Pedro de Meneses, entre 1415 e 1435. Sob ordem do rei D. Afonso V, que visava ressaltar a presença portuguesa no Norte da África, o cronista da corte que sobreveio a Fernão Lopes deve ter dado início à redação do texto em 1460.

Brocardo (1997), de cuja edição nos servimos para análise lingüística, assinala a existência de dez manuscritos referentes à Crônica do Conde D.Pedro de Meneses ${ }^{15}$, de Zurara, tendo tomado como objeto de edição o manuscrito mais antigo, a saber, o Manuscrito de número 439 da Biblioteca Geral da Universidade de Coimbra, cuja cópia deve ter sido realizada em princípios do século XVI. Segundo a editora, a crônica permaneceu inédita até fins do séc.XVIII, período em que o Abade Corrêa da Serra transcreve pela primeira vez o manuscrito. No entanto, as intervenções do editor foram tão profundas e em tão variados níveis de modo que configurou uma verdadeira modernização do manuscrito editado. Sendo

\footnotetext{
${ }^{14}$ De agora em diante a Crônica de D.Pedro de Menezes será indicada através da sigla CPM.

${ }^{15}$ Brocardo ressalta que o título atribuído à Crônica é diferente dos outros nove por ela estudados. Estes traziam em cada um deles pequenas variantes em torno da formulação: "Cronica dos feitos do conde dom Pedro de Menezes, primeiro capitão que foi na cidade de Cepta".
} 
assim, o texto resultante não trazia "o conjunto de hábitos de escrita próprios de uma sincronia", oscilando entre fidelidade e inovação ${ }^{16}$.

Com o objetivo de servir de objeto para estudo lingüístico, Brocardo afirma ter evitado regularizar ou normalizar a transcrição, procurando manter a variação e instabilidade das particularidades gráficas e lingüísticas do manuscrito, embora tenha alterado profundamente a pontuação, de acordo com as normas atuais.

Sabe-se que o texto é temática e cronologicamente a continuação da Crônica da Tomada de Ceuta, que ao lado de outra crônica de Zurara- A Crônica de D.Duarte de Menezes- deixam perceber estreitas relações de intertextualidade, formando uma trilogia apelidada pelos editores como "crônicas marroquinas""17.

Entendemos que, por se tratar de um texto de caráter histórico comprometido com relatos de guerra e eventos de conquista, a CPM seja documento propício para identificação da língua dos quatrocentos. De fato, a editora acredita que Zurara tenha inclusive tido “oportunidade de recolher de viva voz diversos testemunhos de pessoas que tomaram parte dos conhecimentos descritos", afinal, o cronista escrevia sobre fatos recentes, pouco anteriores à data de redação do documento. Sua escrita parece pouco ficcional, já que, segundo o que relatam seus biógrafos, Zurara tinha distinta visão geo-histórica do momento e dos lugares que descrevia. Além de ser testemunha ocular de alguns dos fatos, os historiógrafos comprovam que Zurara pisou em terras africanas, afim de apurar informações

\footnotetext{
${ }^{16}$ Segundo Brocardo, uma segunda edição do documento teria sido realizada por António Manuel Lázaro em 1990, e teria se intitulado: Gomes Eanes de Zurara. Crônica do Conde D.Pedro de Menezes Continuada Tomada de Ceuta. Edição diplomática e crítica. No entanto, segundo crítica da autora, a edição de Lázaro traz "numerosos erros de leitura, que não podem ser tomados como meros lapsos do editor...". Ela atenta para o fato deste editor realizar "correções" ao manuscrito mediante bases arbitrárias, que, segundo ela, chegariam a "falsear o texto". Falhas na metodologia de edição como as citadas fizeram Brocardo considerar o trabalho de Lázaro como uma reprodução que não é minimamente fiel ao texto de um dos manuscritos, motivos suficientes para reafirmar a importância de se elaborar outra edição.

${ }^{17}$ Zurara é também autor da quase legendária Crônica de Guiné, bastante prestigiada entre historiadores, críticos literários e editores.
} 
in loco- o cronista teve contato com a transmissão oral, tanto quanto empreendeu-se à pesquisa dos acontecimentos.

\subsection{O período investigado}

Conforme expusemos na introdução, a escolha do corpus apóia-se no pressuposto de que o corpus quatrocentista acomoda variações interpretadas como competição de gramáticas (Kroch 1989, 1994, 2001). O debate instaurado em torno desse período contempla ainda outros aspectos como uma possível origem do português implantado no Brasil a partir do quatrocentista. Fato é que o período tem sido reconhecido pela literatura como palco de importantes fenômenos. ${ }^{18}$

Quando se trabalha com dados históricos fatalmente se esbarra nas questões de periodização da língua. No que diz respeito particularmente à Língua Portuguesa, parece não haver unanimidade em relação aos seus períodos históricos, já que os mesmos dependem do interesse do pesquisador, que pode ser de ordem filológica, histórica ou literária ${ }^{19}$.

\footnotetext{
${ }^{18}$ Moraes de Castilho (2001) assume que o PB implantado no Brasil tenha base no português quatrocentista e não no quinhentista, como tem sido assumido por alguns autores. Não adotamos categoricamente a discussão desta última autora, muito embora seu trabalho tenha direcionado nosso olhar para o português desse período, uma vez que é neste que ela encontra construções semelhantes ao PB atual como as construções de tópico retomado, e a duplicação de pronomes possessivos e clíticos (pessoais ou locativos), dentre os quais estudamos os locativos.

19 Teyssier (2004:42) em História da Língua Portuguesa, debate a questão da periodização da Língua Portuguesa citando desde os estudiosos que distinguem sua história em dois grandes períodos- arcaico (que iria até Camões do séc.XVI), e moderno (que começaria em Camões); até aqueles que baseiam a periodização na própria tradição histórica-Idade Média, Renascimento, Modernidade- além daqueles que se inspiram nas escolas literárias e seus respectivos séculos.

Aqueles pesquisadores notadamente interessados nas questões lingüísticas parecem convencionar que o período arcaico inicia-se com os primeiros documentos editados em Língua Portuguesa (e não mais em Latim) como $O$ Testamento de Afonso II (1214), e a Notícia do Torto, cujo texto é, na verdade, um rascunho que se acredita ter sido escrito entre 1210 e 1216. Para delimitar o término deste período, adotamos a periodização de Mattos e Silva (1994:251) que considera que se pode aceitar, baseando-se em Leite de Vasconcelos e Lindley Cintra,

“(...) que o período arcaico se inicia com os primeiros documentos em português e que muitas de suas características se estendem até pelo menos 1536/1540, datas dos inícios da normativização da língua.”
}

Isso significa que, se há um processo de normativização, tem-se inevitavelmente um tempo de novos padrões lingüísticos. 
Na tradição filológica o português se dividiria entre Português Arcaico ou Medieval, Clássico e Moderno, conforme representamos no esquema abaixo:

\section{Periodização do português segundo a tradição filológica}

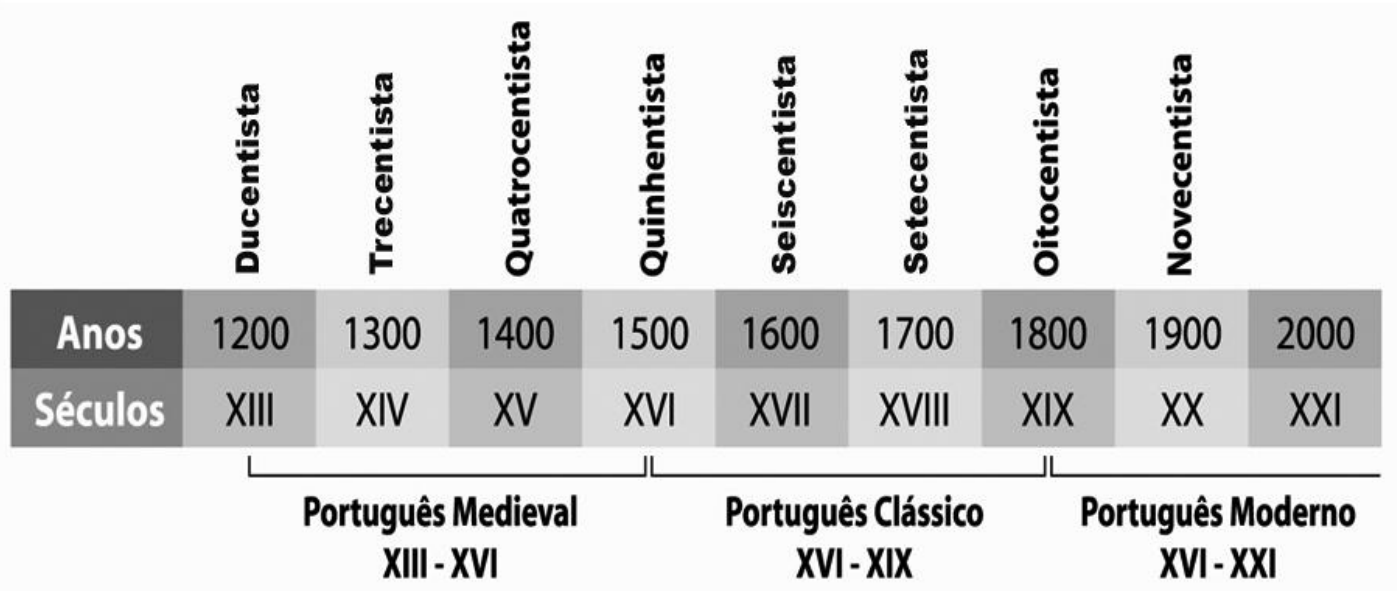

De acordo com a tradição, o português quatrocentista estaria enquadrado no âmbito do Português Medieval.

Já na proposta dos historiógrafos Castro (1991) e Cardeira (2005), bem como na proposta de Galves, Namiuti e Paixão (2006), o texto quatrocentista faria parte do que convencionaram chamar de Português Médio. Os estudos de Cardeira e Castro indicam que os textos da segunda metade do século XIV e XV já trariam algumas formas do período subseqüente, e por esse motivo, propuseram um período transitório entre o Português Arcaico e o Português Clássico (da filologia): trata-se do Português Médio. Galves (2004 apud Namiut

Fato é que, de maneira geral, o primeiro momento histórico a estabelecer-se na linha do tempo é o período arcaico do português que engloba desde os primeiros documentos escritos em português até aqueles que aparecem no final da Idade Média. Já que esse período arcaico constitui-se num rico acervo de escritos medievais, ficou também a ele o legado de período medieval ou Português Medieval. O momento histórico subseqüente seria o então chamado Português Clássico que faz fronteiras entre o Português Antigo e o Moderno, ou entre o período medieval e o moderno, período este em que se documentam os textos quinhentistas mais tardios, os seiscentistas e os setecentistas. 
2008) estende o Português Médio até início do período setecentista, que seria seguido do Moderno. Deste modo, o quadro de periodização ficaria resumido em Português Arcaico (até fins de XIV), Médio (dos fins de XIV até início do séc.XVIII) e Moderno (séc.XVIII em diante $)^{20}$. O esquema abaixo, que retiramos de Namiut (2008), deixa visualizar algumas das propostas de periodização do português. A primeira linha corresponde à visão clássica da filologia, a segunda relaciona-se com a proposta do Português Médio de Castro e Cardeira, e a terceira, traz a proposta de Galves, Namiut e Paixão (2006):

\section{Periodizações alternativas do português}

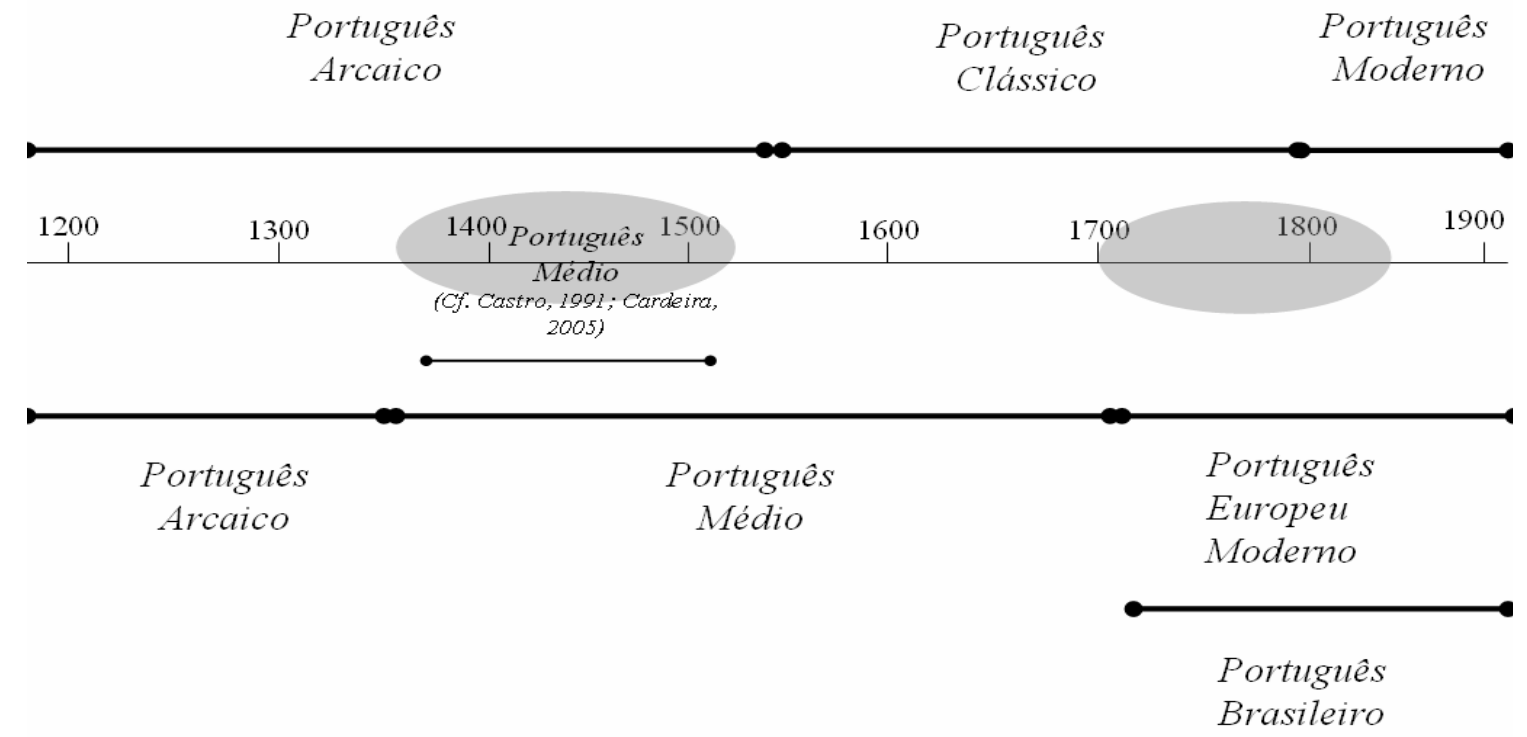

(apud Namiut, 2008)

\footnotetext{
${ }^{20}$ Galves, Brito e Paixão de Souza (2005) e Paixão de Souza (2004) identificam no séc.XVIII a emergência do Português Europeu e do Português Brasileiro Modernos.
} 
Há ainda pesquisas como Moraes de Castilho (2005) que dividem o período arcaico/medieval em duas fases: uma que iria até os fins dos sécs. XII- XIV, e outra que iria dos sécs. XV-XVI.

Independentemente das discussões em torno da periodização do português, lançamonos à análise do português quatrocentista, época que é, notadamente, e por si só, um cenário de variações e um prenúncio de mudanças importantes que estariam por vir.

Feitas as considerações em torno da escolha do corpus, passamos à explanação da forma de análise dos dados, bem como à apresentação do envelope de variação.

\subsection{Forma de análise dos dados}

Para a análise estatística dos dados, seguimos a metodologia da sociolingüística quantitativa (Cedergreen \& Sankoff, 1974). Com um método de descrição bastante peculiar, a corrente variacionista encarregou-se de desenvolver seu próprio sistema de pesquisa, o de cunho estatístico. Para que sua natureza quantitativa de tratamento dos dados fosse real e eficaz foi de grande valia a contribuição do "Variabel Rules", de Cedergreen e Sankoff. Tratase do apelidado Varbrul, um pacote de programas computacionais destinado ao cálculo de freqüências de usos gramaticais, a partir da escolha de fatores condicionantes e uma variável dependente.

A seguir, arrolamos os grupos de fatores condicionadores da posição de Locs, LocPs e PPs. Os dados foram codificados e submetidos ao Varbrul, na versão Goldvarb (2001), para o cálculo de freqüência. 


\subsection{O envelope de variação}

Em (1.4.1) apresentamos os grupos de fatores selecionados para a análise dos PPs, pronomes locativos (Locs) e pronomes locativos preposicionados (LocPs). Em (1.4.2) apresentamos os fatores lingüísticos utilizados na análise específica de Locs e LocPs, e em (1.4.3) os fatores da análise comparativa de PPs e LocPs ${ }^{21}$.

\subsubsection{Grupos de fatores condicionadores do movimento de PPs, Locs e LocPs}

Abaixo arrolamos os fatores elencados para a análise comparativa de PPs, Locs e LocPs.

Grupo 1: Movimento de PPs, Locs, LocPs x Posição in situ

As sentenças abaixo exemplificam um PP/Loc/LocP movido e um in situ, respectivamente, conforme os grifos:

(1) ....perfeições dos autos que delles procedem $(\mathrm{CPM} / \mathrm{p} .74)^{22}$

(2) ...me parece que ora faz a este caso (CPM/ p.187/1330)

(3) porque ally nõ há arautos

(4) mandou-lhe que os deyxasse ally (CPM/ p.333/1 780)

(5) caa nõ ousarão dally partyr (CPM/p.173/112)

(6) rrogo-te que nos vamos daquy (CPM/p.434, 1116)

\footnotetext{
${ }^{21}$ Realizamos análises de Locs e LocPs, por ambos consistirem de pronomes locativos, um preposicionado e outro nõa; e PPs e LocPs, por serem, ambos, constituintes encabeçados por uma preposição. Embora os LocPs possam ser entendidos como PPs, estamos os analisando separadamente, por trazerem características de Locs e de PPs.

${ }^{22}$ Indicamos as referências dos dados assim: documento de origem (CPM), seguido de página (p.x) e linha (l.x) de onde os dados foram extraídos.
} 
Essa é a variável dependente. Todos os demais fatores foram cruzados com esse, já que, diante das hipóteses que norteiam o trabalho, buscamos saber se há variação na posição de PPs/Locs/LocPs no português quatrocentista.

Grupo 2: Forma do Complemento da Preposição do PP (Pronome/SN)

Abaixo, o grifo em (7) representa um PP complementado por um pronome e em (8) um PP complementado por um sintagma complexo.

(7) o qual vos pede por merçee que vos syrvais delle (CPM/p.199/1599)

(8) pedindo-lhe que ho guardasse das limgoas repreensoras e mordazes (CPM/p.178)

Verificaremos através desse estudo:

a) se o peso do NP complemento do PP interfere em sua posição, já que NPs complexos (ou pesados) não apresentam a tendência de movimentar-se ao longo da sentença (Nascimento, 1984).

b) se o pronome favorece o movimento do PP. Se o PP movido for constituído de P+Pronome pode-se estabelecer um paralelo entre a posição desses PPs e a posição dos clíticos ou dos pronomes fracos.

Esta análise não é necessária para Locs e LocsPs, já que ambos constituem-se de formas leves por definição.

Grupo 3: Função Sintática do PP/Loc/LocP (Adjunto, Argumento) 
Nas ocorrências que se seguem, trazemos exemplos de PPs, Locs e LocPs, um na função de adjunto e outro de argumento, nesta ordem (conforme mostram as sublinhas):

(9) quando por ella pelejardes (CPM/ p.205/1763)

(10)e dos outros que com elle concorrerão (CPM/ 175/166)

(11) pareceo-lhe que teriam ally como castello (CPM/ p.233/ 1453$)$

(12)Que ell rrey de Portugall aquy leixou (CPM/p.254/ 1 123)

(13) E poque o comde dom Pedro hera lomge dally (CPM/p.228/1334) ${ }^{23}$

(14) seguymdo algũs mouros que por ally vio hir (CPM/p.614, 1818)

Uma de nossas principais hipóteses é que o movimento de PPs/Locs/LocPs está condicionado à natureza argumental ou de adjunto. Ressalte-se que não trabalhamos com adjuntos sentenciais, pois estes têm, naturalmente, grande mobilidade na sentença (Rocha, 2001).

Grupo 4: Categoria que seleciona o PP/Loc/LocP (Verbo, Nome)

Os termos grifados dizem respeito aos PPs, Locs e LocPs, selecionados pelos verbos e nomes (nesta ordem) que aparecem negritados:

(15) aquilo que dos outros dizem (CPM/p.187/1314)

(16) semtio que hera dino daquella homrra (CPM/ p.186/1288)

(17) Que farã os que aquy nasceram e viveram toda sua vida (CPM/p.212/1946)

(18) alldeas que ally são acerca (CPM/277, 1710)

(19) foy achado que llevarã dally b $\widetilde{\mathrm{e}}$ VI coroas (CPM/p.639, 1 216)

(20) gemte que ficara dally mui orgulhosa (CPM/ p. 245/ 1744)

\footnotetext{
${ }^{23}$ Todos os LocsPs pesquisados desempenham a função de adjunto.
} 
Com essa análise pretendemos observar se complementos de verbos são mais propensos ao movimento do que complementos de nomes.

Grupo 5: Posição do sujeito em relação ao verbo (anteposto/posposto)

A seguir, $(21,22)$ trazem sublinhados PPs, (23-24) Locs e (25-26) LocPs, todos exemplificando uma ocorrência de sujeito anteposto e outra de sujeito posposto (em negrito):

(21) como quer que Nosso Senhor Deus disse ao povo (CPM/p.208, 1185)

(22) seguiu-se que naquelles dias se ajumtarão muitos daquelles juízes (CPM/p.284,1232)

(23) que aquelle fidalgo ally cõtinue (CPM/p.201/1667)

(24) armas que ally tinha Joham Preto (CPM/p.542, 1 201)

(25) disse-lhes que elles nõ sayssem dally (CPM/p.340, 1934)

(26) caa dally foi ferido Gomçallo Velho (CPM/p.473,1725)

Através dessa análise queremos investigar qual a relação do sujeito com a posição de PPs/Locs/LocPs. O fato de sujeitos apresentarem-se antepostos ou pospostos ao verbo predeterminaria a posição dos demais constituintes, seguindo uma ordem padrão?

Grupo 6: Tipo de Sentença (Adjetiva, Adverbial, Completiva)

Conforme os parênteses, os exemplos demonstram um modelo de sentença adjetiva, completiva, nas quais estão inseridos PPs, Locs e LocPs: 
(27) virtude que sempre nelle conheci (CPM/p.174/141)

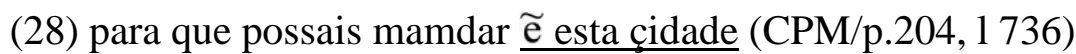

(29) sabia que elle tinha temçom de se apartar (CPM/p.197/1545)

(30) Aabu homem gramde...o quall logo ally foi morto (CPM/p.247, 1784)

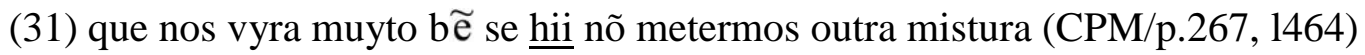

(32) a terceira pomba...mostra que quem de todo hi rretardar (CPM/p.252, 188)

(33) duas legoas que são dally ao paull (CPM/p.691, 1 465)

(34) porque partymdo dally de noite (CPM/p.574, 1 1012)

(35) foram avisados que nõ partyssem dally (CPM/p.596, 1378)

Pretende-se observar qual tipo de sentença favorece o movimento de PPs/Locs/LocPs. Hipotetiza-se que a subida dos sintagmas encabeçados por uma preposição seja favorecida na presença do elemento $[-\mathrm{Wh}]^{24}$, o qual pode aparecer seja nas adjetivas, seja nas completivas.

\subsubsection{Grupos de fatores comparativos do movimento de Locs e LocPs}

Grupo 7: Tipo de Locativo (Hi/ ahi, aquy, aly/ ally, lla/la)

Observe, em destaque, as ocorrências dos locativos com e sem preposição:

(36) hũ outeiro que hy está (CPM/p.240/1 610)

(37) porque pelos tempos vymdouros aquy he neçessario (CPM/p.207/1818)

(38) parte daquelles que ally ficavão (CPM/p.215/cap.XI. /119)

\footnotetext{
${ }^{24}$ Tarallo (1983) interpreta esse elemento como complementizador; Kato (1993) distingue o pronome relativo do complementizador, de acordo com a tradição gramatical. Mioto e Figueiredo Silva (1995) mostram a presença do elemento que nas interrogativas de tipo $\mathrm{WH}$.
} 
(39) meu tio que lla morava (CPM/ 223/1197)

(40) que por emtemder de por hy outro proveitoso rremedio (CPM/p.620, 1973)

(41) Ca som daquy a nossas fortallezaz dês legoas gramdes (CPM/p.573, 1981)

(42) emtemdeo que os outros hiriã jaa afastados dally (CPM/p.670, 1992)

(43) será bẽ que vos vades pera laa com essa gemte (CPM/p.499, 116$)$

Com o grupo 7 queremos identificar se as diferentes formas pronominais (preposicionadas ou não) ocupam posições diferentes.

Grupo 8: Referencialidade do Loc/LocP (+Anafórico ou -Anafórico)

Abaixo, (44) representa um locativo + anafórico e (45) um locativo - anafórico. Já (46) e (47) são exemplos de LocPs, o primeiro de valor +anafórico e o segundo de valor (anafórico).

(44) aquele Senhor de de Moxequeçi que ally hera por fromteiro (CPM/p.294, 1 856)

(45) Mas nos outros que aquy ficamos (CPM/p.211/l 928)

(46) Partymdo dally foram a Bolonha...e partymdo dally foram ter hũa legoa avamte de Jazira (CPM/p.432, 1 1093)

(47) que quamdo daquy party (CPM/p.700, 1709)

Uma de nossas hipóteses é a de que os pronomes locativos possam apresentar a tendência de subirem para posições mais altas conforme sua anaforicidade e/ou menor referencialidade, com o intuito de se aproximarem de seu antecedente no discurso, 
contrariamente à hipótese de Cardinaletti e Starke (1999), segundo a qual os pronomes fortes ou expressões-R é que subiriam para posições mais altas na sentença.

\subsubsection{Grupos de fatores comparativos do movimento de PPs e LocPs}

Grupo 9: Tipo de preposição que encabeça o PP/LocP (de, $a$, em, outras)

Veja-se, a seguir, algumas preposições que podem encabeçar PPs (48-51) e LocPs (52$55)$ :

(48) quando se delles espediam (CPM/ p.211/1914)

(49) até que se fossem fazemdo ao seu senhorio (CPM/p.209/1878)

(50) quando me servirão nas outras guerras (CPM/p.208/1846)

(51) que se acharia com elles muyto melhor que doutra guysa (CPM/p.209/1879)

(52) Ca passava dally per Anafee a carregar trigo (CPM/p.309, 1 169)

(53) disseram-lhe os escudeyros do comde que per ally hera o caminho (CPM/p.390, 1 74)

(54) quatro besteyros que abastaram pera laa (CPM/ p.483, 1 1985)

(55) como ate aquy nõ temos feita nenhũa cousa (CPM/p.387, 111)

Através deste fator, pretende-se verificar se há uma preposição que propicia o movimento do PP/LocP, para, num estágio posterior, verificar se a preposição de apresenta comportamento semelhante ao locativo-partitivo ende, e se $a$ preposição em assemelha-se ao locativo $h i$. 
Perseguimos ainda duas hipóteses:

a) O movimento de PPs/LocPs é favorecido pela preposição de, que carreia a noção de assunto (tópico do discurso). Neste caso, o PP movido pode ser identificado como um elemento topicalizado;

b) o movimento de PPs ocorre em estruturas em que o PP não pode ser retomado por um resumptivo, devido à perda deste. É o caso do partitivo ende e do locativo hi, pronomes que são atestados no Português Medieval. O partitivo-locativo ende deixou de ser atestado nos textos quatrocentistas (Mattos e Silva, 1989) e o locativo hi, um pronome com função exclusivamente anafórica, ao tomar a forma aí adquiriu carga de deiticidade (Muidine, 2000). A contra senso, hipotetiza-se que a existência do clítico lhe, que pode retomar um PP introduzido pela preposição $a$, impeça o movimento do PP na encaixada ( * Quem ao João entregar-lhe o livro...)

Grupo 10: Caso Abstrato do PP/LocP (genitivo, dativo, ablativo, locativo, partitivo)

Os PPs e os LocPs são, por definição, sintagmas oblíquos e exercem funções casuais.

Os PPs comportam em sua semântica os Casos genitivo, dativo, e ablativo. Este último que abrange os Casos locativo e partitivo ${ }^{25}$. As sentenças abaixo representam: (56) um PP genitivo, (57) um PP dativo, (58) um PP ablativo, (59) um PP locativo e (60) uma ocorrência de PP partitivo:

(56) certo que nenh $\sim \mathrm{u}$ autor de novo lyvro possa ser escuso (CPM/p.178, 1 115)

(57) aquilo que dos outros dizem (CPM/p.187, 1314)

(58) virtuosos baroes que com elle ...trabalharão (CPM/p.174, 1 46)

\footnotetext{
$25 \mathrm{Na}$ análise dos casos ablativos, obedecemos ao seguinte critério: existem os ablativos puros, que desempenham funções adverbiais e os ablativos que desempenham funções semânticas específicas de lugar e origem ou proveniência, classificados como locativos e partitivos.
} 
(59) mamtymemtos que heram na frota (CPM/p. 208, 1852)

(60) pois dos mouros nõ houve semtymemto (CPM/p.274, 1647$)$

Já os LocPs só foram encontrados nos casos locativo (61), partitivo (62) e ablativo (63):

(61) mamdou algũs escudeyros que se fossem pera laa (CPM/p.482, 1947)

(62) partyda que dally fezerom (CPM/p.422, 1 849)

(63) dissera que...e que dally em breve teriam carreira segura (CPM/p.335, 1219)

Através desse fator, podemos observar se algum Caso provoca o movimento de PPs e LocPs; e, o mais relevante para a pesquisa: sistematizar qual é a proporção de PPs e LocPs locativos e partitivos, para que sejam comparados com os pronomes locativos.

A seguir, são abordadas as análises qualitativas, seguidas das considerações finais.

\subsection{As análises qualitativas}

Para a análise do local de pouso dos PPs/Locs e LocPs, baseamo-nos nos trabalhos de Martins (1994), Rizzi (1995), e Belletti (2002). A posição do clítico esclarece o locus de pouso nas posições em CP; a posição de sujeito deixa identificar o lugar de ancoragem na periferia interna da sentença; o grupo verbal, assim como nos trabalhos voltados para a posição do clítico (Cyrino 1993, Pagotto 1993) é relevante para observar ulteriores posições para Locs/LocPs e PPs movidos. Seguem-se alguns exemplos (PPs/LOcs/LocPs grifados e clíticos em negrito):

(64) Ca hy lhe ficara despois fazer aquelle mesmo dano (CPM/p.239,1590) 
(65) gemte que se hy aloja (CPM/p.276, 1679)

(66) comsyderando que eu nom vos lexo aquy (CPM/p.206, 1780

(67) que os leixasse laa hir (CPM/p.275, 1661)

(68) que por nenhua guisa o fezesse (CPM/p.198,1570)

(69) quem vos nesto aja de servir (CPM/p.199,1599)

(70) quamdo me servirão nas outras guerras (CPM/p.208,1846)

(71) e assy que vos sereis delles servido (CPM/p.198, 1576)

(72) dezer-lhe ....que por ally o faria hyr a lugar.. (CPM/p.594,1340)

(73) porque não avia mais de um dia que se dally partirão (CPM/p.364,1491)

(74) mandou [..] escudeyros seus que se fossem pera laa (CPM/p.482,1947)

(75) que os leixasse laa hir (CPM/p.275, 1661)

\subsection{Considerações finais do capítulo}

Neste capítulo apresentamos a metodologia adotada para o trabalho.

Tendo justificado a escolha do corpus e período estudados, passamos a apresentar os três conjuntos de dados que se distribuíram entre PPs, Locs e LocPs. Para isso, elencamos os grupos de fatores que, em virtude das hipóteses apresentadas, foram tomados como condicionadores do movimento desses constituintes, e submetidos à análise quantitativa.

Apesar de se tratar de uma pesquisa quantitativa e também qualitativa, devemos dizer que não adotaremos integralmente a teoria de variação e mudança dentro da abordagem laboviana, já que, além de trabalharmos apenas com um texto, deixamos de lado fatores sociais inerentes a essa linha de pesquisa. Nesse sentido, tomaremos o método de Labov principalmente como instrumento estatístico.

O uso de Lightfoot (1999), como classicamente se faz na investigação filiada ao modelo gerativo, se dará apenas no nível teórico. Nosso olhar sobre a variação dos dados se 
dará à luz do conceito de competição de gramáticas nos termos de Kroch (1989, 1994, 2001). Isto porque o ponto de vista do primeiro prega uma mudança lingüística abrupta, que se faria no momento da fixação de parâmetros durante a aquisição de linguagem, evento que não podemos recuperar de um único documento ${ }^{26}$.

Situando-se na esfera sociolinguiística, Kroch (op.cit) propõe que a mudança sintática seja um processo gradual, que deixa transparecer a disputa entre duas gramáticas tidas como incompatíveis, que convivem até que uma supere o uso da outra. Há casos em que a convivência resulta não no desaparecimento de uma das formas, mas sim na especialização de uma delas, afim de que consiga sobreviver no sistema. Não se trataria, portanto, de um processo abrupto.

Dentro desta perspectiva, a pesquisa mostrará Locs, LocPs e PPs, que, como formas concorrentes, disputam os mesmos contextos sintáticos, ora alternando entre uma e outra, ora aparecendo de maneira isolada, e por vezes, uma redobrando a outra, como é o caso do redobro de um locativo por um PP. Formas que desaparecem e outras que sobreviveram também serão apontadas, em parte porque a concorrente foi se extinguindo, em outra, porque a vencedora se especializa.

\footnotetext{
${ }^{26}$ Nos estudos de lingüística histórica, o julgamento de gramaticalidade de sentenças não pode ser recuperado devido à limitação dos corpora, que são todos escritos. Entretanto, esse tipo de julgamento pode ser recuperado quando se faz uma leitura exaustiva de diversos documentos de diversos autores. Com um acervo satisfatório de sentenças que apontarão para evidências positivas e negativas, o analista pode chegar a julgamentos do que teria sido uma sentença bem formada numa dada época. Uma vez que estudamos um único documento podemos falar, sim, numa competição de gramáticas, já que de fato encontramos formas em variação nesse recorte de tempo (como alguns tipos de movimentos) que não são atestadas em períodos posteriores ao analisado. Poderíamos inferir, desta forma, que estamos capturando um período de variação dentro de um recorte sincrônico que culminará numa mudança lingüística ao longo da diacronia.
} 


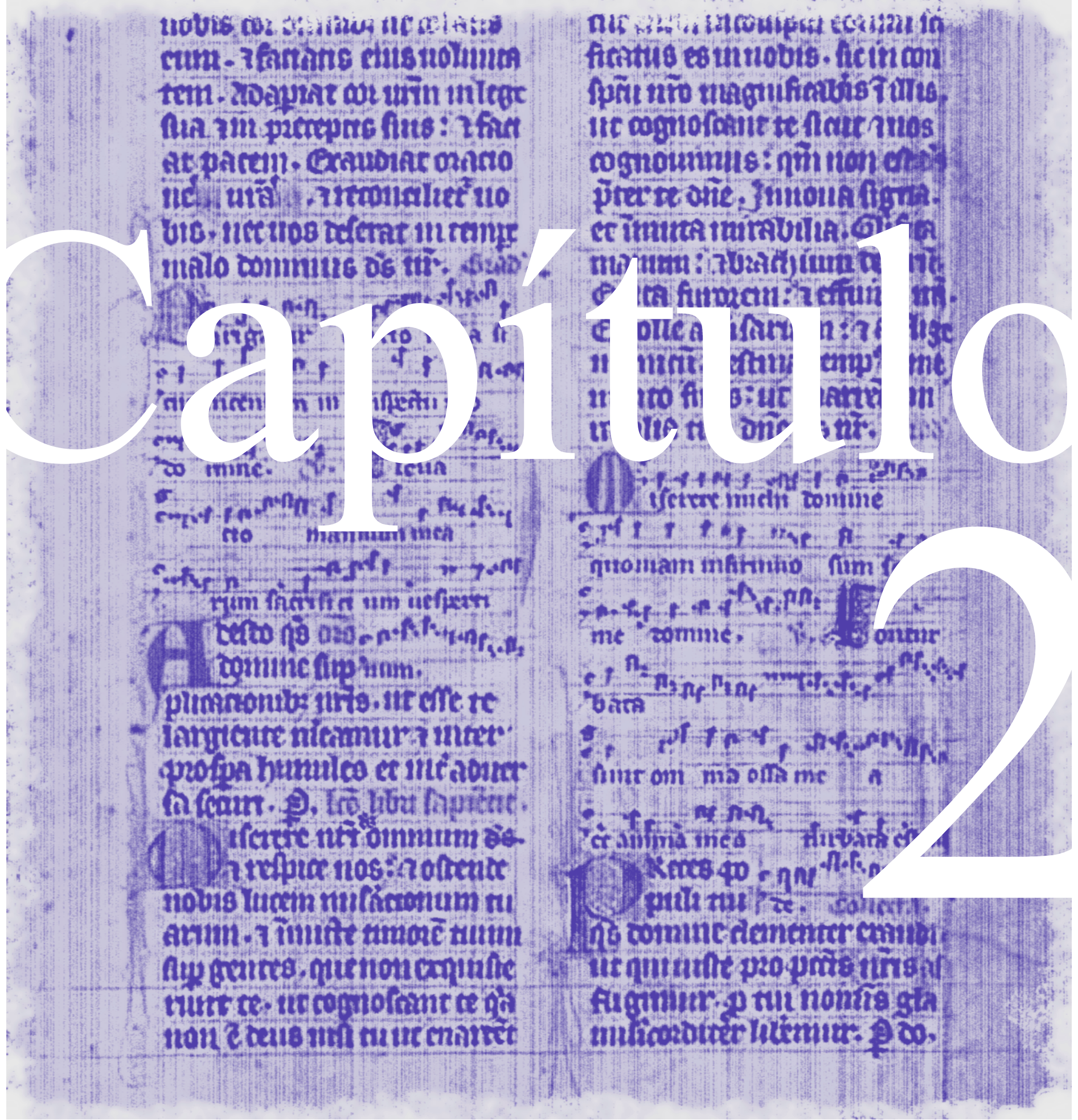




\section{PRESSUPOSTOS TEÓRICOS}

\section{Introdução}

ste trabalho filia-se à Teoria de Princípios e Parâmetros (doravante TPP) -
proposta por Chomsky $(1981,1986)$ como embasamento teórico para interpretação
dos dados.

Explicamos, neste capítulo, que a corrente lingüística chomskyana, também conhecida como Sintaxe Gerativa, postula uma visão de língua interna, advinda de uma epistemologia de caráter biológico-funcional, que pressupõe a existência de uma Gramática Universal inata à espécie humana, gramática esta constituída de princípios universais a todas as línguas, e parâmetros que variam entre elas. Propondo um conceito computacional, o modelo de Chomsky arquiteta o processamento das sentenças, que se representam através de esqueletos funcionais arbóreos, construídos sob a concepção hierárquica da Teoria X-barra.

Mostraremos que as categorias funcionais, que são projeções estruturais motivadas por propriedades morfológicas (e funcionais), constituem-se no lócus da variação paramétrica. O percurso histórico dessas categorias permitirá visualizar desde as principais propostas de projeções funcionais como $\mathrm{CP}$ e IP, bem como seus clássicos desdobramentos, os quais poderão acomodar os dados desta pesquisa.

O capítulo está dividido assim: A primeira seção (2.1) dedica-se à apresentação da Teoria de Princípios e Parâmetros e passa brevemente por algumas concepções de variação 
lingüística e paramétrica. Num segundo estágio, em (2.2) fazemos um breve histórico das categorias funcionais propostas pela teoria para se formar o esqueleto estrutural das sentenças. Em (2.3) abordamos a proposta de Martins (1994) que utiliza os clíticos como fronteira entre constituintes topicalizados e interpolados; e sua relação com o especificador múltiplo de AgrS. A seção (2.4) mostra como Martins utiliza a categoria sigma para alocar alguns tipos de verbos e em função dos clíticos, derivar a próclise e a ênclise. Já nas seções (2.5) e (2.6) apontamos os trabalhos que serão especialmente utilizados para a interpretação dos dados, por tratarem das periferias da sentença: (2.5) traz a proposta de um CP desmembrado de Rizzi (1997), e (2.6) explana a proposta de uma periferia interna da sentença (Belletti, 2002).

\subsection{A Teoria de Princípios e Parâmetros}

O modelo teórico TPP, surgido no âmbito dos estudos comparativos da teoria gerativa, concebe a Gramática Universal como sendo constituída de dois princípios abstratos:

i. os que recebem a designação geral de princípios, que, por serem caracterizados como rígidos, absolutos e invariáveis, consistem em propriedades e operações presentes nas gramáticas de todas as línguas naturais;

ii. os parâmetros, que, por consistirem de opções determinadas pela experiência lingüística, acomodam a variação interlingüística ou variação paramétrica.

Os parâmetros são considerados princípios abertos e a sua fixação é feita por meio de uma escolha binária de valores [+] ou [-], durante a aquisição da linguagem. A escolha por um dos valores é que determinará as diferenças entre as línguas. Assim, teremos duas gramáticas distintas toda vez que o estabelecimento do parâmetro $X$ for feito positivamente por uma comunidade lingüística e negativamente por outra. 
Um exemplo de variação paramétrica é o licenciamento ou não do sujeito nulo referencial. O inglês marca negativamente este parâmetro, não licenciando o sujeito nulo; o italiano o marca positivamente, o que explica o licenciamento do sujeito nulo nessa língua:

(a) Maria parla francese. (b)___ parla francese.

(b) Maria speaks French. (b) *__ speaks French.

Dentro deste modelo teórico, que é notadamente mental, tudo o que a criança tem que aprender, no processo de aquisição da linguagem, são as propriedades gramaticais que estão sujeitas à variação paramétrica entre as línguas. Diante dos parâmetros restritos a escolhas binárias, a tarefa da criança limita-se à atribuição do valor [+] ou [-], o que é feito a partir do input (dados lingüísticos) a que está exposta.

O input lingüístico que deriva do meio ambiente em que se encontra a criança consiste de enunciados dos adultos (Língua-E). É da interação desse input com a GU, de que toda criança é dotada, que se processa a aquisição da linguagem, entendida como o desenvolvimento da Língua-I, um saber individual e internalizado, conforme mostra a figura abaixo:

Figura 1

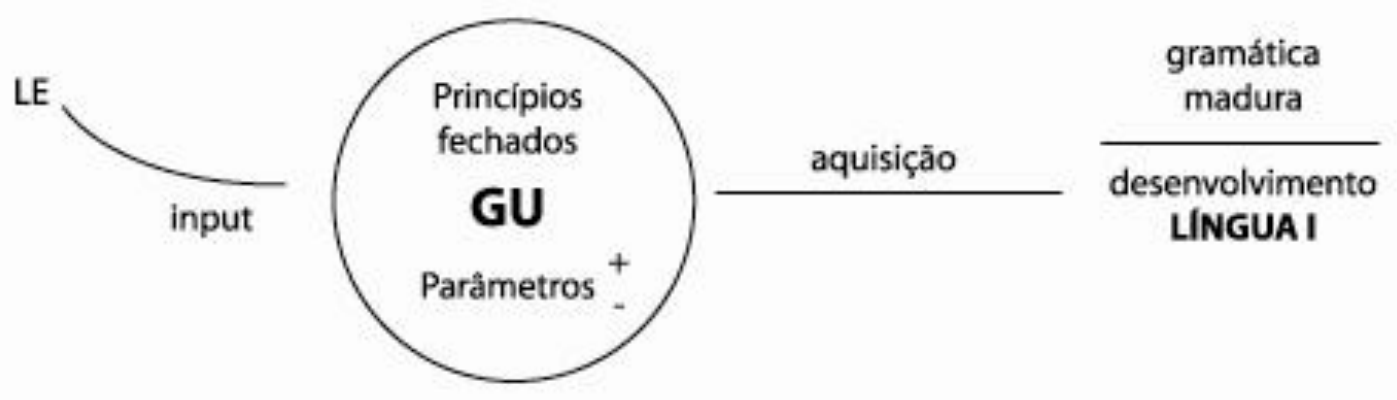


Apesar de estarmos assumindo a TPP como maneira de explicar a gênese da variação paramétrica por meio da marcação de valores binários no momento da aquisição, faz-se necessário retomar algumas das principais concepções de variação, ainda que de maneira sintética. É o que fazemos na subseção a seguir.

\subsubsection{Diferentes concepções de variação e mudança}

Lightfoot (1999) admite que a GU seja uma espécie de genótipo lingüístico rico, trazendo em si as estruturas fundamentais básicas de gramáticas, independentemente das experiências lingüísticas. Neste sentido, o papel das experiências lingüísticas na aquisição da linguagem seria o de filtrar e lapidar características que irão imergir numa gramática tida como madura. Nessa abordagem, a GU faria parte de uma dotação genética herdada pelos seres humanos que, a partir de eventos empíricos, desembocaria num fenótipo que é a gramática ou língua resultante.

Assim como gramáticas distintas podem gerar enunciados diferentes (Língua-E), como é o caso da diferença entre o inglês e o italiano, no que concerne ao parâmetro do sujeito nulo; enunciados superficialmente idênticos podem receber diferentes estatutos (Língua-I), propiciando a mudança lingüística. Isto acontece porque os dados lingüísticos primários $^{27}$ que se constituem no input a que uma criança está exposta, não serão iguais aos que servirão de input para outra, e, por isso, geram gramáticas individuais com aspectos diferentes.

Deve-se notar que essa teoria de mudança difere epistemologicamente da concepção social de gramática. Os adeptos da mudança de perspectiva sociolingüística pressupõem um processo que seja gradual e não abrupto como propõe o conceito mentalista de Lightfoot.

\footnotetext{
${ }^{27}$ Lightfoot (1999) chama os dados lingüísticos primários de PLDs- primary language data.
} 
A língua, vista pelo modelo variacionista laboviano como um fato social, não poderia ser diferente da sociedade: é heterogênea e sujeita a variações e mudanças. Além de fatores internos de ordem estrutural que já prevêem sua capacidade de transformação, existem também fatores externos como faixa etária, sexo, realidade socioeconômica, no âmbito das características individuais dos falantes, e contexto situacional, estilo pessoal, que são fatores relacionados à situação imediata da enunciação. Todos esses elementos e outros como a cultura e organização político-geográfica de uma determinada comunidade social, agem no sentido de fazer uma mesma língua, ser falada de diversas maneiras, num mesmo período de tempo, por um mesmo grupo de falantes. É a fatores como esses que a sociolingüística se propõe a descrever e analisar.

Os modelos variacionistas diferem-se dos modelos inatistas a começar de seu ponto de partida: o primeiro grupo se preocupa com a língua-E e o segundo com a língua-I. Outra diferença entre os modelos reside no próprio conceito de variação. Para o variacionismo existem regras categóricas e existe a variação destas regras. As regras categóricas, invioláveis, são obedecidas por todos os falantes, que é o que ocorre, por exemplo, com o preenchimento do pronome sujeito na língua inglesa e francesa. No caso do português esta regra não é categórica, é um caso de variação. As formas lingüísticas em processo de variação são chamadas variantes lingüísticas, e o conjunto dessas variantes forma o que é conhecido na literatura de cunho social como variável lingüística. Labov (1972) elenca três estágios intrínsecos à mudança origem, propagação e conclusão. No primeiro estágio, uma entre inumeráveis variações é falada por um pequeno grupo de falantes. A propagação, que se dá num segundo estágio, ocorre quando essa variação ou variante é adotada por um grande número de pessoas de modo que esse novo uso começa a entrar em contraste com a forma 
antiga (conservadora) em detrimento desta, a inovadora. A mudança ${ }^{28}$ chega ao seu estágio de conclusão no momento em que a forma inovadora ganha uma regularidade tal que elimina a competição das variantes de modo a suprimir a quantidade da mais antiga ou até mesmo desbancar sua supremacia ${ }^{29}$.

Portanto, na linhagem social, a mudança é ativada a partir de inovações da língua-E, ou seja, dos enunciados de adultos, que, sob o ponto de vista da TPP, alteram os dados que servirão de experiência para a próxima geração de falantes.

Neste trabalho nos centraremos nas propostas de competição de gramáticas de Kroch (1989, 1994, 2001), já que estamos trabalhando com um único corpus, e por se tratar de um único período, o quatrocentista, será inviável falarmos em mudança lingüística, mas inevitável falarmos em variação. Sob o olhar de Kroch (1994), poderia se falar numa espécie de diglossia interna refletida nos textos. As estruturas em variação, competindo entre si, disputam os mesmos espaços até que uma forma vença e a outra desapareça. É por isso que, quando se trabalha com dados históricos, a composição do corpus deve se pautar em textos

\footnotetext{
${ }^{28}$ É de fundamental relevância que se saiba que a variação é indispensável para que ocorra uma mudança lingüística. Um dos mais conhecidos conceitos labovianos é o de que a mudança sempre implica em variação, mas a variação não implica necessariamente a mudança.

${ }^{29}$ Do ponto de vista sociolingüístico, durante o processo de mudança, alguns aspectos relativos aos valores de prestígio e estigma da variante são levados em conta pelo falante. As formas de prestígio são aquelas variantes utilizadas pelo grupo social considerado superior e elitizado pela sociedade. Em primeira instância, a variante de prestígio não apenas é tida como a forma padrão como também é imitada pelas classes inferiores. Por outro lado, as variantes empregadas pelos estratos mais baixos da população são, em sua maioria, estigmatizadas. Esse estigma só vai diminuindo quando a classe dominante pouco a pouco o incorpora em sua gramática. O resultado é que a forma deixa de ser estigmatizada. Os autores da área têm mostrado que o pronome tônico em posição de objeto é um bom exemplo disto. Como a forma conservadora de utilizar o clítico acusativo é avaliada pelos falantes como artificial e pedante, ao mesmo tempo que o emprego de ele em função de objeto direto ainda é um pouco evitada em situações ou registros mais formais, a opção que surge é a de simplesmente apagar o objeto direto. Tem-se, assim, a origem do objeto nulo em PB.

Weinreich,U., Labov, W. \& Herzog, H. (1968) descrevem cinco problemas a serem analisados durante o progresso de uma mudança lingüística. O primeiro, a restrição, é aquele em que se verifica quais são as restrições universais que agem sobre a mudança. Na fase de transição, tem-se os estágios intermediários da mudança, ou seja, que rumos essa mudança toma. No denominado encaixamento, correlaciona-se as variáveis lingüísticas entre si com aspectos que vão desde os elementos do próprio sistema lingüístico até o contexto social. No estágio de avaliação, checa-se que avaliação fazem os membros da comunidade de fala com respeito à mudança, e que informações expressivas essas variantes veiculam. E, finalmente no nível de implementação, investiga-se que motivações provocaram a mudança dentro de seu momento e lugar.
} 
escritos que possam, de fato, refletir o vernáculo de um certo período de tempo.

$\mathrm{Na}$ próxima seção, tratamos das categorias funcionais, que justamente têm sido tomadas como o espaço das mudanças lingüísticas e paramétricas.

\subsection{Categorias funcionais}

Assumimos que a variação paramétrica na Gramática Universal (GU) é responsável pelas particularidades de língua para língua. Localiza-se inteiramente nas chamadas categorias funcionais e se relaciona com as propriedades morfológicas destas categorias (Ouhalla, 1991, Chomsky, 1992).

Raposo (1993) assume com Pollock (1989) "que os fenômenos gramaticais mais importantes nas línguas humanas têm lugar na articulação entre as categorias lexicais e as categorias funcionais" e têm em vista que sua variação é determinada pelas propriedades variáveis das categorias funcionais. As categorias funcionais são concebidas pelo autor, por um lado como predicados de elevação, determinando a subida de argumentos do esqueleto lexical para o especificador dessas categorias, e, por outro, como núcleos que atraem cabeças lexicais. A posição das categorias lexicais é observada de maneira abstrata na estrutura arbórea (1) abaixo em que, F1, F2, etc. representam categorias funcionais arbitrárias, e L a categoria lexical básica das orações: 
Estrutura (1)

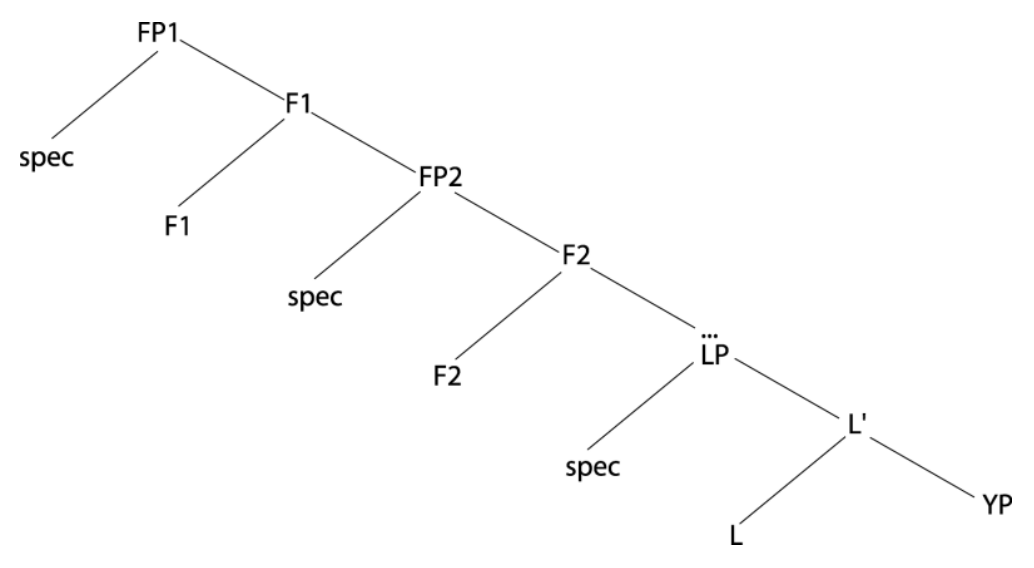

Em tese, as categorias lexicais $(\mathrm{N}, \mathrm{V}, \mathrm{A}, \mathrm{P})$ constituem uma classe aberta, que têm conteúdo semântico e são responsáveis pela atribuição de papéis temáticos a seus argumentos e, as categorias funcionais, por outro lado, formam uma classe fechada, cuja natureza é morfêmica, e não atribuem papéis temáticos. Estas últimas são definidas em termos de traços gramaticais (traços- $\phi$ de Chomsky, 1981). Tendo isto por pressuposto, as categorias funcionais selecionam propriedades morfológicas que sejam compatíveis com seus traços, tomando em seguida os argumentos do verbo com os quais se relaciona gramaticalmente. Num outro estágio, as categorias funcionais selecionam propriedades categoriais, que significa dizer, que selecionam outras categorias gramaticais. Tendo isso em vista e voltando a observar a estrutura de FPs e LPs representada acima, as categorias funcionais têm muito a dizer sobre a estruturação e ordem linear dos sintagmas e das palavras.

Durante o desenvolvimento da teoria as categorias funcionais foram sendo estabelecidas de maneira a convencionar os sintagmas através de siglas: VP, IP, CP, etc ${ }^{30}$. Até a década de 80 do século precedente, os gramáticos gerativistas limitavam-se a trabalhar com

\footnotetext{
${ }^{30} \mathrm{O}$ sintagma verbal ficou convencionado pela teoria como VP (verbal phrase), o sintagma flexional como IP (inflectional phrase), o sintagma complementizador como CP (complementizer phrase), etc.
} 
o grupo VP (grupo verbal), até que uma versão posterior da Teoria X-barra ${ }^{31}$ propôs a integração sistemática das categorias funcionais CP (Grupo de Complementizadores) e IP

(Grupo de Flexão) ${ }^{32}$, conforme mostra a estrutura (2):

\section{Estrutura (2)}

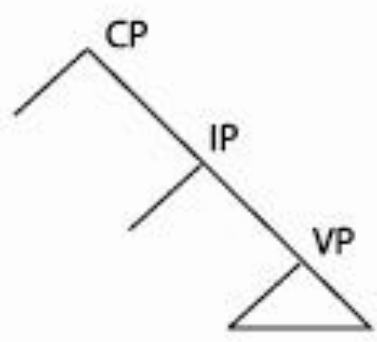

De modo geral, os trabalhos da área têm apontado para outras projeções funcionais existentes entre $\mathrm{CP}$ e $\mathrm{IP}^{33}$. As novas projeções que foram sendo propostas eram identificadas

31 Originalmente o esquema X-barra destinava-se à acomodação das categorias lexicais. As classes lexicais tinham a capacidade de selecionar semanticamente seus argumentos e categorialmente seus complementos. Assim como as categorias lexicais, passou-se a admitir que as categorias funcionais também estão sujeitas ao esquema X-barra, dispondo de uma posição para especificador e outra para complemento. Como essas categorias representam o esqueleto gramatical das línguas naturais, podem se manifestar com afixos ou não. Lopes (1999) comenta que a primeira motivação do esquema X-barra às categorias funcionais deu-se em função da falta de coerência entre as categorias lexicais e categorias como $\mathrm{S}$ e $\mathrm{S}$ ' em relação à endocentricidade. Em outras palavras, isto quer dizer, que, as categorias lexicais eram uniformemente endocêntricas, e $S$ e $S$ " não representavam claramente uma projeção hierárquica com a seleção de um núcleo. A partir de então, passa-se a incorporar ao sistema as projeções de CP e IP. CP (sintagma complementizador), correspondente a S que acomodaria os elementos [+ ou - wh] e IP (sintagma flexional), correspondendo a $S$ ' , seria a projeção máxima da categoria $\mathrm{I}(\mathrm{nfl})$, que, segundo a proposta inicial, conteria os traços de [+ ou - tempo/ + ou - concordância], traços estes que definiriam uma sentença como finita ou infinita.Fukui \& Speas (1986) é considerado o primeiro trabalho a estabelecer distinção entre as categorias lexicais e as funcionais. Para eles e também Abney (1987), o DP é também proposto como uma categoria funcional que projeta a categoria gramatical determinante.

${ }^{32}$ Há que se citar também a projeção de DP, grupo de determinantes. Na teoria gerativista de Chomsky (1970) e Stowell (1981), os NPs, são, na verdade, um complemento de DP assim como VP é complemento de I, e IP é complemento de $\mathrm{C}$.

${ }^{33} \mathrm{O}$ esqueleto funcional tem sido aceito como universal. Há, de fato, línguas em que uma determinada categoria não se apresenta na forma fonética, mas estaria sim representada em Forma Lógica. Deste modo, ainda que não visível, toda categoria funcional seria prevista no funcionamento da língua. Lopes (1999:62) entende que através dessas propostas, há uma "ordenação" entre as categorias funcionais, que revelaria propriedades intrínsecas ao funcionamento das línguas naturais, que já estariam previstas na GU. Prosseguindo, a autora se pergunta por que, então, a fala das crianças não revelaria desde cedo essas categorias. É nesse sentido, que a autora destaca a importância que o desenvolvimento de uma teoria sobre categorias funcionais trouxe para a área da aquisição da linguagem. Lopes ressalta que para além de constituir num ponto de partida para as hipóteses de aquisição, o estudo das categorias funcionais tem se firmado como espaço das mudanças paramétricas e, portanto, da variação lingüística. Acrescentamos ainda, que as categorias funcionais tem sido há muito tempo o espaço da descrição de inúmeros fenômenos em diversas línguas. No programa minimalista, inclusive, os parâmetros continuam a ser tomados como propriedades das categorias funcionais, "porém vistas agora a partir da atuação 
por certos tipos de traços morfológicos em seu núcleo, traços estes fundamentais para determinar os processos de movimento.

Um considerável debate se instaura em torno do sintagma flexional, por IP conter traços de dois elementos- tempo e concordância. Afinal, qual dos dois elementos I estaria projetando?

Pollock (1989) traz uma proposta que se tornou clássica por desmembrar o IP em duas categorias funcionais distintas TP (tempo) e AGrP (concordância). Em AGrP estariam os elementos de concordância que contêm os traços de número, pessoa, gênero e Caso (traços- $\Phi$ de Chomsky (1981)), e em TP estariam especificados os traços de + ou - passado/futuro. O exemplo abaixo que mostra uma ordenação diversa entre verbo e alguns advérbios em francês e inglês (3) esclarece sua proposta:

(3) a. Jean voit a peine Marie.

b. John barely sees Mary

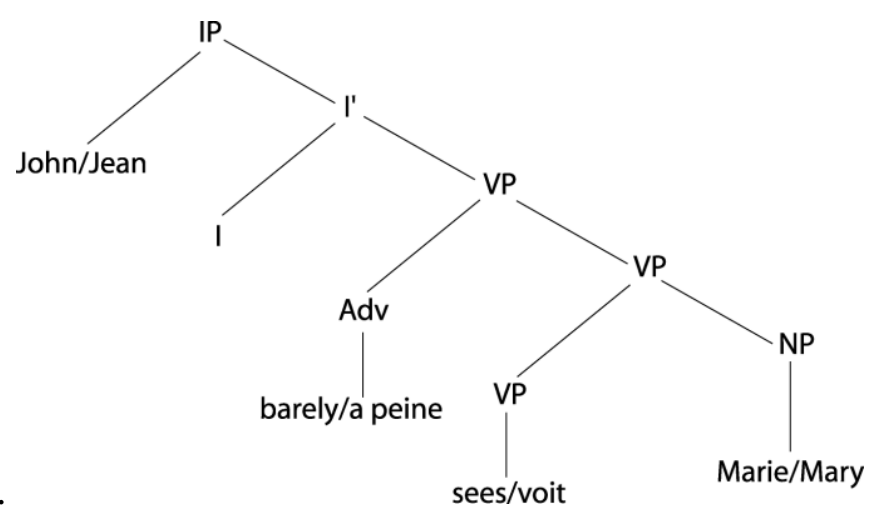

Em francês a categoria funcional I é morfologicamente forte e determina a subida do verbo através do processo de incorporação; no inglês, I é morfologicamente fraca. A subida do verbo realiza-se apenas na forma lógica (LF). A diferença nas propriedades de I nas

de seus traços constitutivos" (Lopes 1999). Logo, não há dúvidas de que as categorias funcionais possam trazer respostas para os fenômenos nas mais diversas línguas. 
referidas línguas implica numa ordem variável de palavras que irá depender da posição do verbo e do advérbio. Esta análise comparativa leva Pollock (op.cit.) a concluir que a projeção funcional IP é literalmente composta de (ou desmembrada em) duas projeções independentes e tão díspares como TP e AgrP. ${ }^{34}$ A necessidade de duas projeções funcionais deriva também dois tipos de movimento: i) o "movimento longo" do verbo, que é o movimento de V para a posição do núcleo mais alto, To , e ii) o "movimento curto do verbo", ou seja, o movimento de V para o núcleo mais baixo, Agro.

Veja, abaixo, que segundo Pollock (1989) com o desmembramento de Infl em T (ou I para alguns lingüistas) e AGR, o primeiro nódulo T passa a c-comandar AGR. Veja estrutura (4):

\section{Estrutura (4)}

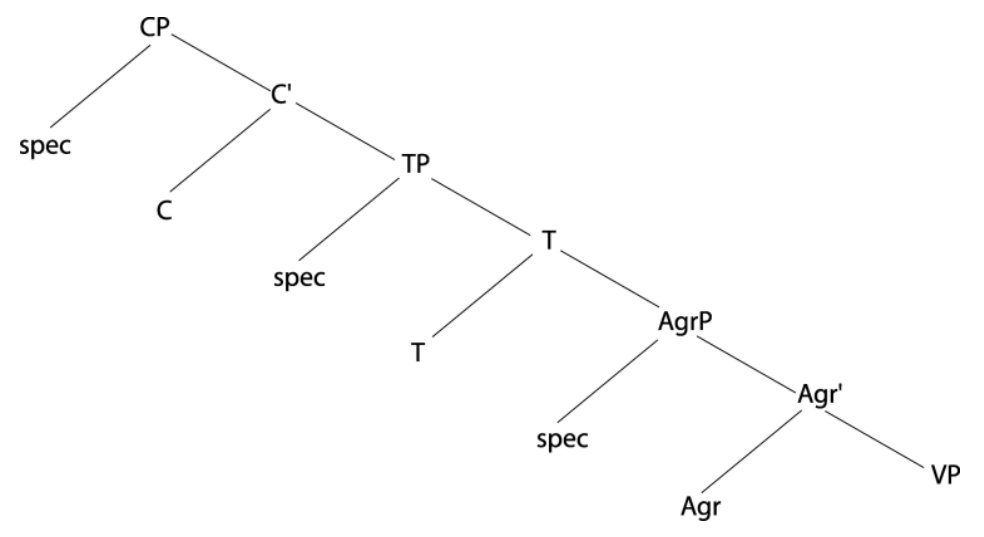

Belletti (1990) ${ }^{35}$ e Chomsky (1992) adotam a estrutura acima, porém com o AgrP ccomandando TP, invertendo, assim, a proposta de Pollock. Belletti (1990) adota uma versão

\footnotetext{
${ }^{34}$ Muitos estudiosos gerativistas incluem elementos funcionais da oração como Aspecto, Modo, e outros como desmembramentos de IP. Em frases negativas uma projeção máxima NegP intervém entre AgrP e TP. Para esta discussão nos detemos a AgrP e TP.

${ }^{35}$ Discussões em torno da hierarquia estrutural e a ordem em que aparecem as categorias funcionais são muito comuns quando se parte de diferentes concepções de desenvolvimento gramatical durante a aquisição da linguagem. Oliveira (2000:233), em seu livro Frases assertivas e sua variação nas línguas românicas: seu papel na aquisição, retoma Rizzi (1992) que sustenta a hipótese de que a gramática da criança não tem representação
} 
do Princípio de Espelho Baker (1985) de modo que conclui que "a projeção flexional mais alta da frase deve ser aquela de Concordância, dada a ordem linear dos morfemas ligados ao verbo" (1996: 43). Para ela, a concordância é precedida pelo morfema de tempo, isto é, o verbo passou primeiro pela projeção de Tempo, para depois checar a concordância.

Chomsky (1991) propõe ainda a divisão de AgrP em AgrSP com um Agr para sujeito, e AgrOP, um Agr para objeto. Para ele, dentro do sistema de flexão, AgrSP teria a função de relacionar um sujeito a um predicado. Essas posições serão retomadas na próxima seção que aborda o estudo em que Martins debate a capacidade de AGRS selecionar especificadores múltiplos resultando na interpolação de constituintes entre o clítico e o verbo (cf. 2.3).

Ouhalla (1991), por outro lado, soma às categorias funcionais já existentes as projeções de ASP (ecto), PASS (iva), e NEG (ação), que não serão usadas neste trabalho.

É importante ressaltar que NEG como uma categoria funcional independente também foi proposta por outros autores como o próprio Pollock no trabalho de 1989, Chomsky (1991), Laka (1990), Belletti (1990), Ouhalla (1991) e Zanuttini (1991). Para Laka (1993) e Martins (1994), os traços dos operadores de negação e afirmação estariam alocados em $\sum \mathrm{P}$, projeção que estaria entre CP e IP. O especificador de $\sum \mathrm{P}$ hospedaria os constituintes frontalizados. Outras pesquisas procuraram formalizar posições de $\mathrm{F}(\mathrm{oco})$, estudos estes voltados para o $\mathrm{CP}$, conforme veremos mais adiante em (2.3) e (2.4).

No tocante à categoria CP, um importante achado da década de 90, situa-se numa posição mais alta na sentença e destaca-se por trazer informações do discurso ao explicar a subcategorização de orações subordinadas (S’) por um verbo, e por trazer, além do aspecto semântico interno à sentença, outro de ordem externa, a finitude. Observe estrutura (5):

puramente lexical, evocando a necessidade de se postular a existência de nódulos funcionais para se dar conta da análise morfológica e dos fenômenos da ordem. No estágio inicial da aquisição a criança teria estruturas truncadas da sentença, ou fragmentos de proposições. Nessa perspectiva, a criança pode ter desenvolvido TP (conforme Belletti, 1990) mas não AgrP e CP, ou ter desenvolvido TP e AgrP, mas não CP. Esse debate faz parte da hipótese de aquisição de linguagem biológico-mental conhecida como teoria ou hipótese maturacionista, teoria que se opõe à hipótese continuísta. 
Estrutura (5)

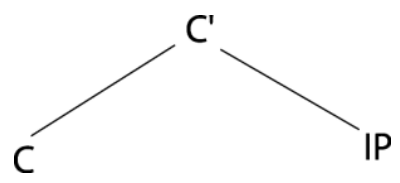

Os verbos, além de subcategorizarem orações subordinadas, "escolhem" o traço [ +ou - Wh] destas. Deste modo, um verbo como perguntar subcategoriza uma sentença cujo Comp é então especificado em [+Wh]; produzindo uma sentença interrogativa. Um verbo como declarar subcategoriza uma sentença cujo Comp é especificado em [-Wh], produzindo uma declarativa.

Para além do traço [+ ou - Wh], há que se observar a realização fonética de Wh:

i. um complementador com realização fonética na posição de Comp (que ou se) determina em português uma flexão(I) finita, ou seja, com especificação de tempo. ii. um complementador vazio, sem realização fonética, determina uma flexão nãofinita .

As proposições acima são facilmente entendidas através dos paradigmas abaixo:

(6) a . Eu penso [ CP [ c que [IP ele passou o exame]].

b. Eu penso $\left[\mathrm{CP}\left[\mathrm{C} \_\right.\right.$[IP ter passado no exame $\left.]\right]$.

Sintetizando a noção contida nos exemplos acima, teríamos o esquema (7): 
Esquema (7)

Perguntar/declarar/pensar

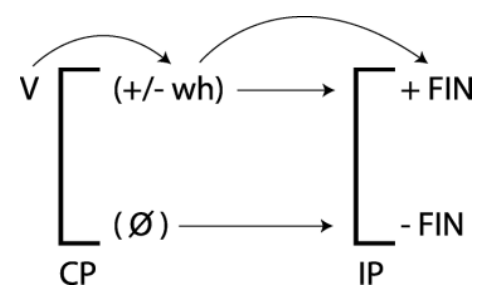

Esse tipo de proposição/esquematização servirá para identificar/julgar qualitativamente o tipo de sentença encaixada em análise ${ }^{36}$.

Línguas como o PB, o francês canadense, certos dialetos do holandês e estágios anteriores do inglês comportam duas posições distintas para os complementadores e para os constituintes WH: C e especificador de C, respectivamente como no exemplo do PB (8).

(8) [CP Quem [ c que [IP falou isso]]]?

No PB rural há, inclusive, relativas de onde com que $e^{37}$ :

(8") O lugar onde que eu fui

No tocante ao português europeu (PE) e outras línguas, a co-ocorrência dessas formas é impossível por obedecerem à regra do Filtro do Comp Duplamento Preenchido:

*[CP constituinte Q [C Complementizador lexical IP]]

\footnotetext{
${ }^{36}$ No capítulo (4), de análises descritivas, adotamos essa esquematização para a classificação do tipo de sentença encaixada estudado. O modo de classificação, entretanto, não foi explicitado no texto, mas serviu como base para a codificação dos dados.

${ }^{37}$ Essa observação foi feita oralmente pela Profa.Dra. Ilza Ribeiro, durante qualificação desta tese.
} 
(9)*This book of wich that I make mencion

*Este livro do qual que eu faço menção

Explorando a periferia à esquerda da sentença, Uriagereka (1992) adiciona o Foco entre a projeção CP e IP que conteria o traço de ênfase e/ou contraste, para explicar a posição de clíticos em dialetos românicos arcaicos. É através dessa categoria adicional $\mathrm{F}$ que ele explica a ênclise em orações raiz do português europeu. $\mathrm{O}$ autor sugere que a ênclise no português é resultado da: subida do V de I para F, incorporando-se em F. Seguindo esta linha, Raposo (1994) assume com Kayne (1990) a existência de uma projeção FP que cumpriria a função de hospedar operadores do tipo negação, exclamação, interrogação, foco, ênfase. Ele mostra que a subida do V de I para F, "isola" o clítico em I, de modo que a ênclise é derivada. Esta última proposta correlaciona-se com as proposições de Martins (1994) e sua teoria para explicar a derivação de ênclise em orações matrizes, discussão que apresentamos na seção (2.4).

No trabalho de Ruveret (1992) encontra-se uma distinção entre Tópico e Foco, de modo que a primeira categoria seria recursiva e a segunda só poderia ocorrer uma vez, como se vê em (10 a e b):

(10a) [тоP A MARIA] [Tор o carro dela] o pneu furou. (Kato, 1987)

(10b) [FOC A MARIA] beijou o Pedro.

Para atender aos propósitos de seu trabalho, Ruveret (op.cit.) assume a existência de categoria funcional WP, projetada entre CP e IP, a posição de Wakernagel onde pousariam os clíticos e FocoP, destinada aos elementos focalizados. 
Há também trabalhos que se dedicaram a teorizar o movimento de núcleos. Chomsky (1992) abordou, sobretudo, o movimento de verbos motivado por checagem de traços morfológicos. Segundo sua abordagem, as categorias funcionais seriam especificadas para traços- $\mathrm{V}$, que serão checados com o verbo, e, seguindo o mesmo raciocínio, os traços-N, seriam checados com o especificador.

Nesta seção retomamos rapidamente as principais categorias funcionais propostas na teoria, das quais faremos uso apenas das projeções básicas de CP (e seus desdobramentos), IP, VP.

Nas próximas seções tratamos de trabalhos que abordam tanto movimentos como scrambling do objeto que geram tanto construções com constituintes interpolados (2.3) e movimentos do verbo para uma projeção $\sum$, gerando construções de próclise/ênclise (2.4); quanto movimentos para periferias da sentença, tais como Top e Foc de CP (Rizzi, 1995) na seção (2.5), e Top e Foc de IP de (Belletti, 2002), na seção (2.6).

Veja-se na sequência, a estrutura sentencial proposta por Martins, a partir da qual podemos localizar as posições de Top, Foco, e interpolação em função da posição do clítico.

\subsection{A interpolação e especificador múltiplo de Agrs}

Martins (1994) observou que entre os sécs. XII e XV o português passa de uma gramática enclítica com interpolação de vários elementos para uma gramática proclítica com interpolação apenas da negação ${ }^{38}$ entre os sécs XVI e XVIII. A partir do séc. XVIII reaparece a ênclise e há queda brusca da interpolação da negação em orações matrizes.

Com a finalidade de explicar a estrutura da interpolação, Martins (op.cit) assume que o

\footnotetext{
${ }^{38}$ Os dados do português clássico levantados por Namiuti (2003),vão ainda mais longe e mostram que antes de caírem na obsolescência, a interpolação da negação foi a preferida até o séc.XIX, conforme trataemos mais adiante, no próximo capítulo.
} 
clítico marca a fronteira entre constituintes topicalizados ou focalizados e constituintes interpolados $(\mathrm{X})$, entre os quais se encontra o OD que foi movido por scrambling, propõe a seguinte estrutura sintática da sentença:

Comp - Tópico (ou adjunto frásico) - foco - clítico - XPs interpolados -verbo

A interpolação, marcada na estrutura acima por X, pode ser vista nos exemplos abaixo:

(11) E com todas as pertenças que aos ditos casaes lhes dereitamente pertencem

$$
=\text { tópico } \quad \mathrm{cl} \quad \mathrm{X}
$$

(12) e sse pela uentura uos alguém a dita vya enbargar

$$
=\text { tópico } \quad \mathrm{cl} \quad \mathrm{S} \quad \mathrm{X}
$$

Tanto o clítico como os XPs interpolados são complementos do verbo que o antecedem, devido à variação entre VO e OV no português dos sécs. XIII a XVI. A ordem $\mathrm{OV}$, ainda que pouco freqüente, era atestada nas orações subordinadas, nas orações principais introduzidas por sintagmas qu-, quantificadores, sintagmas focalizados e certos advérbios:

(13) Sse pela uentura uos alguen a dita vya enbargar (1296/Doc.notariais)

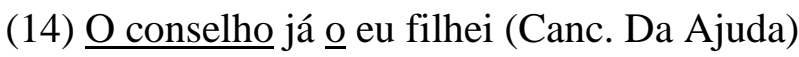

(15) Estas pallavras e outras muitas the disse dom egas moniz 
Em (13) a ordem (S)OV é resultado de scrambling do objeto para a esfera de IP. No português medieval e clássico, a ordem OV também era resultado de operações como deslocação à esquerda clítica (14) e de focalização (15), distinguindo-se das frases com scrambling porque estas exibiam, geralmente, a ordem SOV.

A autora enfatiza que a presença do sujeito não é um fator único para indicar se temos uma estrutura com scrambling, pois em frases com scrambling do objeto, o sujeito pode ocorrer posposto ao verbo.

A ordem OV resultante de scrambling do objeto ocorre no mesmo tipo de frases em que a próclise é obrigatória e a interpolação possível: trata-se das orações subordinadas e das principais introduzidas por operadores (sintagmas qu-, quantificadores, sintagmas focalizados e certos advérbios).

Com relação ao tipo de constituinte que podia ser interpolado, a autora constatou que qualquer elemento que pudesse ocupar uma posição pré-verbal na oração poderia ocorrer interpolado, fosse um advérbio de negação, fosse um sujeito, um sintagma preposicionado ou adverbial, complementos verbais, particípios, infinitivos, mais de um constituinte, ou simplesmente algo como um quantificador, vocativo ou redobro do clítico. Justamente neste tipo de orações (as dependentes) encontrava-se um contexto propício para o scrambling de objetos.

Para Martins, o objeto está em Spec-AgrS, pois o núcleo AgrS tinha, no português medieval e clássico, a capacidade de selecionar especificadores múltiplos, ou seja, podia abrigar em seu domínio o sujeito e o objeto (ou mais de um complemento verbal) simultaneamente, e gerar, assim, a interpolação de constituintes.

(16) de quem quer que [ uos $\underline{\text { alguum enbargo }}$ sobrel quiser poer 
Ela propõe que os elementos movidos por scrambling ocupam a posição de especificador e não de adjunção:

a. nas subordinadas o sujeito (não topicalizado) tem como posição final SpecAgrS;

b. no português medieval e clássico não se atestam casos de scrambling de longa-distância, apenas o de média distância. O scrambling de longa distância sempre envolve o movimento $A^{\prime}$ (= adjunção). O tipo de scrambling que existe no português medieval e clássico envolve movimento A.

Com a perda da propriedade de selecionar múltiplos especificadores para Agr, a operação scrambling de média-distância deixou de ser uma opção gramatical no português provocando inclusive mudanças radicais na colocação dos clíticos.

Segundo Martins, no português e no espanhol dos séculos XIII a XVI, havia variação entre ênclise e próclise nas orações principais afirmativas (salvo nas orações não introduzidas por operadores). Depois do séc. XVI, ocorreram duas mudanças:

i. desaparecimento da ênclise nas orações principais (salvo nos casos em que o verbo ocupava posição inicial);

ii. desaparecimento da interpolação de XPs nas subordinadas e nas principais introduzidas por operadores.

$\mathrm{Na} 1^{\mathrm{a}}$. fase o verbo permanece em AgrS; não vai para $\sum$. A próclise é derivada quando o verbo e o clítico estão ambos incorporados no núcleo AgrS; a interpolação de XPs é 
derivada quando o clítico ocupa a posição de Spec-AgrS (a posição mais externa) e constituintes movidos por scrambling ocupam posições de Spec-AgrS mais internas, numa configuração de projeção de especificadores múltiplos pelo núcleo funcional AgrS.

Quando a configuração de múltiplos especificadores deixa de ser permitida, a ênclise nas principais e a interpolação nas subordinadas também deixam de existir. Na mesma época, desaparece também a ordem (S)OV resultante da anteposição do Objeto por scrambling.

Mais adiante no tempo (não se sabe exatamente a partir de quando), a ênclise passou a ser a única opção gramatical nas orações principais afirmativas. Da fase 2 para a fase 3 há uma mudança radical: passa-se a ter a ênclise generalizada, nas orações principais afirmativas não introduzidas por operadores. A ênclise passa a ser derivada quando o verbo, incorporado em AgrS juntamente com o clítico, é excorporado para $\sum$ e o clítico fica em AgrS.

Segundo Martins, a perda da ênclise (em variação com a próclise), da interpolação e do scrambling está correlacionada com a perda, a partir do séc. XVI, dos pronomes fortes acusativos no português. A perda dos pronomes fortes acusativos se deve à impossibilidade de serem licenciados em Spec-Agr, pois, a partir dessa época, a estrutura sentencial portuguesa passa a exibir apenas uma posição AgrS. Deixando de selecionar especificadores múltiplos, Agr não pode disponibilizar posições de especificador para abrigar os complementos verbais, e, deste modo, a possibilidade de interpolar constituintes da sentença.

Este trabalho mostra-se relevante sobretudo pelo fato de propor um estrutura sentencial que nos permite, através do clítico, localizarmos elementos que estão em Top e Foco se estiverem à sua esquerda, interpolados se estiverem entre ele e o verbo, e in situ, se estiverem à sua esquerda.

Quanto à discussão em torno do especificador múltiplo de AgrS, devemos ressaltar que sua relevância está em explicar que, em decorrência da perda da capacidade de AgrS comportar mais de um especificador, trouxe efeitos colaterais na língua, sobretudo no que diz 
respeito à colocação dos clíticos. Para Martins, a ênclise nas orações principais, a interpolação e os pronomes fortes acusativos deixaram de ser atestados no português pós séc.XVI em virtude disso. Tendo-se em vista que um dos fenômenos examinados nesta tese é a interpolação de PPs e Locs no séc.XV, parece-nos plausível correlacionar os fenômenos.

Com a próxima seção, apresentamos a proposta de Martins de uma categoria $\sum$ e a derivação de clíticos antes e depois de verbos.

\subsection{A Categoria Sigma e os clíticos}

Para dar conta da ênclise no PE, Martins (1994) correlaciona a posição dos clíticos à existência da construção de VP-nulo.

Segundo a autora, a colocação dos clíticos e o VP nulo dependem de uma mesma propriedade gramatical abstrata, a saber, a natureza forte ou fraca da categoria funcional Sigma (doravante, $\Sigma$ ). Esta categoria funcional, como o locus da definição de valores de verdade - afirmação e negação, nos termos de Laka (1990), contém traços que codificam os valores de polaridade da frase (afirmativa, negativa, modal) e, situa-se, na estrutura frásica, entre Comp e AgrS.

A posição nuclear de $\sum$ tem de ter conteúdo visível. Nas respostas afirmativas o verbo se move para $\sum$ na sintaxe visível, nas línguas em que são fortes os traços-V de $\sum$ (que é o caso do PE). O VP-nulo é legitimado pela categoria funcional com traços fortes, numa relação especificador-núcleo com $\sum$, da mesma forma que pro é licenciado numa relação especificador-núcleo com AgrS forte.

Martins propõe que, nas frases afirmativas do PE e do galego, línguas em que $\Sigma$ contém traços-V fortes, o verbo também move na sintaxe visível para o seu núcleo e o clítico permanece em Agr, posição em que verifica o traço de concordância [+específico]. Dessa 
forma, a ênclise é resultado do movimento do verbo para uma posição mais alta e da permanência do clítico em Agr, conforme mostra a representação esquemática em (17) a seguir:

(17). O Antonio vio-o ontem.

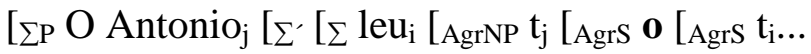

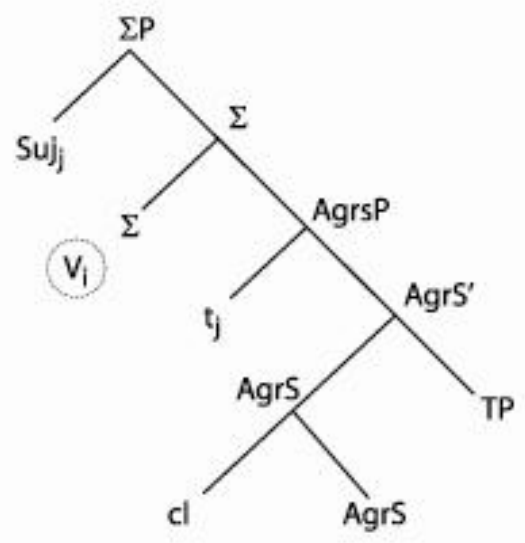

Italiano, castelhano, catalão e francês são línguas que se caracterizam pelo fato de a categoria $\sum$ conter traços- $\mathrm{V}$ fracos. Conseqüentemente, o alçamento do $\mathrm{V}$ para o núcleo de $\Sigma$ não se dá na sintaxe visível. Por tratar-se de um movimento que só ocorre em Forma Lógica, a presença do verbo em Agr explica a posição de próclise dos clíticos dessas línguas.

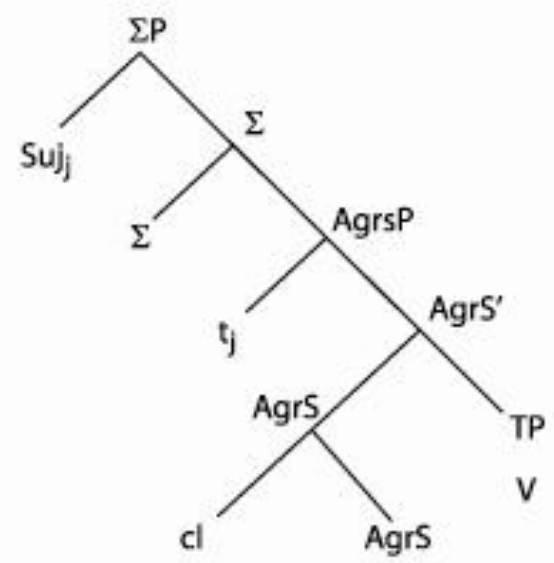


Em frases negativas a ênclise nunca é derivada, ainda que $\sum$ tenha traços- $\mathrm{V}$ fortes, pois a posição nuclear $\sum$ é ocupada pelo marcador de negação predicativa. Como o lugar já está ocupado, não haverá movimento visível do verbo para essa posição.

Nas orações subordinadas os clíticos são sempre proclíticos (em todas as línguas românicas e em todos os períodos) porque $\sum$ move-se para $\mathrm{C}$ formando um núcleo complexo [C $\left.\sum \mathrm{C}\right]$. Como esse núcleo tem conteúdo lexical, o verbo não pode mover para lá.

Além dos valores universais de Sigma, afirmação e negação, o português apresenta ainda a opção de instanciar $\sum$ como $\mathrm{F}($ oco):

(18). Quem realmente lhe deu o tiro?

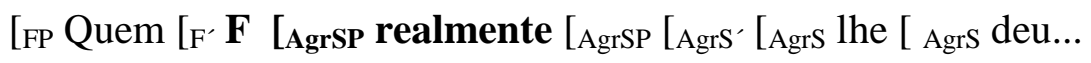

Contrariamente a $\Sigma /$ Af e $\sum / \mathrm{Neg}$, F é “não V-relacionado" isto é, F não contém traçosV. Como SpecFP é uma posição não L-relacionada ou seja, uma posição A`, pode alocar operadores, sintagmas qu-, sintagmas focalizados, quantificadores (afirmativos e negativos) e certos advérbios. Sempre que FP é projetado, a próclise é derivada, pois como F não tem traços-V o verbo não sobe para essa posição, ficando em AgrS para a verificação da morfologia verbal.

Com esta seção mostramos como Martins (1994) utiliza os traços-V da categoria funcional $\sum$ para explicar as posições dos clíticos em relação ao verbo, e também para revelar que essa categoria instancia uma posição de Foco (F) que por não ser V-relacionada, e por não envolver movimento do verbo, sempre gera a próclise. Estudos sobre os clíticos podem ser úteis já que os tomaremos como delimitador de fronteiras sintáticas, admitindo a proposta de Martins (1994). 
As duas próximas seções tratam das periferias da sentença e se mostrarão particularmente importantes pra a interpretação dos dados. Em (2.5), a seguir, apresentamos o desdobramento da periferia esquerda de Rizzi (1997).

\subsection{A Periferia Esquerda e o desmembramento de CP}

Rizzi (1997) desmembra a categoria CP que passa a abrigar as categorias semânticas de Tópico e Foco. Estas categorias, quando ativadas, ficam inseridas em C, entre as especificações de força e finitude que, respectivamente, iniciam e finalizam o sistema C, como mostra o esquema (19) abaixo:

$$
\text { CP [ FORÇA.....(tópico)...(foco).....(tópico).... FINITUDE ] IP }
$$

Com as projeções de força e de finitude, que encerram o sistema $\mathrm{CP}$, busca-se formalizar a comunicação com o que há dentro e fora da sentença. A projeção de força relaciona o sistema $\mathrm{C}$ com os sistemas cujas estruturas encontram-se mais acima (isto é, a sentença mais alta ou até mesmo a articulação com o próprio discurso). A especificação de força (Chomsky 1995, apud Rizzi 1997), conforme o esquema (19) acima, engloba complementizadores capazes de informar se a sentença é exclamativa, interrogativa, declarativa ou relativa, fato que poderá auxiliar na análise que faremos de sentenças interrogativas.

A projeção de finitude, ao encerrar o sistema C, relaciona-o com o sistema mais abaixo, IP. Desta forma, identifica-se com elementos do interior da sentença, o que significa que $\mathrm{C}$ estabelece uma especificação de tempo que se coaduna com a especificação de tempo do sistema I. 
Quanto às projeções intermediárias, TopP (articulação de tópico-comentário) e FocP (articulação de foco-pressuposição), elas nem sempre são ativadas. A projeção TopP é recursiva, podendo aparecer antes ou depois da projeção de FocP, que, por sua vez, não apresenta a propriedade de recursividade ${ }^{39}$. Para fins de visualização das estruturas, observe (20) e (21):

\begin{tabular}{|l|l|}
\hline 20$)$ \\
$\begin{array}{l}\mathrm{XP}=\text { tópico } \\
\mathrm{YP}=\text { comentário }\end{array}$
\end{tabular}

$\mathrm{Na}$ articulação tópico-comentário, o primeiro elemento - tópico - expressa informação velha e o comentário expressa informação nova; na articulação focopressuposição, dá-se o contrário, o primeiro elemento - foco - expressa informação nova e a pressuposição traz a informação velha, como mostram os exemplos abaixo:

(22) Seu livro, você deve dar t ao Paul (não ao Bill).

(23) SEU LIVRO você deve dar t ao Paul (não o meu)

\footnotetext{
39 A particularidade interpretativa das estruturas de foco-pressuposição bloqueia a recursividade de focos na sentença, FocP1 - FocP2, pois a pressuposição do núcleo focal mais alto é informação velha, não podendo ser recuperada como informação nova que caracterizaria o FocP2.
} 
A particularidade interpretativa das estruturas de foco-pressuposição bloqueia a recursividade de focos na sentença. A falta de recursividade do Foco é justificada pelo tipo de informação que ele encerra: informação nova.

Para demarcar diferenças entre tópico e foco o autor aplica testes fundamentados na presença de um elemento Wh, a fim de verificar quantos elementos focalizados e topicalizados uma oração pode conter. Em orações matrizes, Rizzi mostra que o operador WH é compatível com um tópico na ordem TOP-WH, mas é incompatível com o foco nas duas ordens FOCO-WH e WH-FOCO.

Tópico

(24 a). A Gianni, che cosa gli hai detto? (Ao João, o que você lhe disse?)

(24 b). *Che cosa, a Gianni, gli hai detto? (O que, ao João, você lhe disse?)

Foco

(25 a). *A GIANNI che cosa hai detto (non a Piero)? (AO JOÃO o que você disse (e não a Pedro?))

(25 b). *Che cosa A GIANNI hai detto (non a Piero)? (O que você disse A JOÃO (e não a Pedro?))

Segundo Rizzi, o operador WH não é compatível com o Foco, independentemente da ordem (25 a e b), pois ambos ocupam a mesma posição na estrutura sentencial.

A projeção de Tópico possui apenas um especificador. Quando Top é projetado, o tópico aloca-se em Spec, TopP. Os adjuntos, por não configurarem casos de tópico, ficam adjungidos a TopP e não em Spec de TopP. 
Rizzi propõe ainda que, em italiano, o operador relativo, ao contrário do operador + Wh, precede o foco e o tópico, como mostram as sentenças abaixo:

(26 a). Ecco un uomo a cui IL PREMIO NOBEL dobrebbero dare.

(26 b).*Ecco un uomo IL PREMIO NOBEL a cui dovrebbero dare.

(Eis um homem a quem O PRÊMIO NOBEL deveriam dar)

(27 a). Un uomo a cui, il premio Nobel, lo danno senz'altro.

(27 b).* Un uomo, il premio Nobel, a cui lo danno senz'altro.

(Um homem a quem, o prêmio Nobel, dão sem sobra de dúvida)

Ao contrário das interrogativas que se mostram incompatíveis com o foco, relativas e foco podem coexistir. Essa compatibilidade entre relativas e foco é evidência de que não ocupam a mesma posição. Para Rizzi, o fato de os relativos aparecerem antes de tópicos e focos é indício de que os relativos ocupam o Spec de Força, posição bem mais acima da posição estrutural de Foco.

Ao assumir que cada categoria semântica possui uma posição própria no eixo sintagmático, Rizzi enquadra-se nos pressupostos minimalistas de Chomsky (1995), em que somente podem ser postuladas as projeções funcionais que possuem uma motivação semântica.

Do CP expandido pelo autor, adotaremos as projeções de Tópico e Foco como posições hospedeiras de PPs, Locs e LocPs movidos para posições altas, bem como assumiremos a incompatibilidade existentes entre Foco e operador WH para identificarmos se temos PPs/Locs/LocsPs em posição de Top ou Foc a partir de sentenças interrogativas. 
Outros casos de movimentos mais baixos poderão ser explicados através da periferia interna à sentença (Belletti, 2002), que resenhamos a seguir.

\subsection{Tópico e Foco da periferia de IP, uma proposta de Belletti}

Assim como Rizzi (1997) desmembra a projeção de CP, Belletti (2002) expande a projeção de IP, propondo posições de Tópico e Foco. Em seção anterior, explicamos que Martins (1994) usa o clítico como "pista" para identificação de fronteiras. Belletti (2002) usa a posição do sujeito como "pista" para delimitação de fronteiras para encaixe de elementos em uma periferia mais baixa. Por esse motivo, passaremos a apresentar a proposta da autora.

Para explicar as estruturas de sujeito pós-verbal (que geram a ordem VS), Belletti (2002), diferencia as estruturas VS resultantes de Inversão Livre (IL) das estruturas resultantes de Inversão Estilística (IE). Para as primeiras (IL), a autora propõe uma posição de Top/Foco na periferia de IP acima de VP, e para o segundo tipo de estrutura (IE), ela assume as análises tradicionais que atribuem a esse sujeito pós-verbal um movimento para a periferia à esquerda da sentença, tratando-se, portanto, de um sujeito "alto".

Como a inversão do sujeito (VS) é um fenômeno generalizado nos romances, o tema tem sido amplamente abordado na literatura e tem se chegado à conclusão de que a "Inversão Livre do Sujeito" é uma propriedade fundamental das línguas de sujeito nulo e está de algum modo relacionada com a possibilidade de sair da posição de sujeito pré-verbal não realizado foneticamente para uma outra posição. Por outro lado, as línguas de sujeito pleno parecem exibir apenas a inversão de ordem estilística.

Belletti mostra que entre as línguas românicas, o francês tem um estatuto especial: exatamente por não se constituir numa língua de sujeito nulo, não exibe o fenômeno da inversão livre do sujeito. Com efeito, o tipo de inversão permitida na estrutura do francês, é a Estrutura de Inversão Estilística (IE) (Kayne \& Pollock (1978), (2001)). Os exemplos abaixo 
revelam os contrastes entre o italiano (língua de sujeito nulo/pro-drop) e o francês (língua não pro-drop):

\author{
(28) a Ha parlato Gianni \\ falou Gianni \\ b* A parlé Jean \\ falou Jean
}

Apoiada nestes exemplos, a autora observa que Inversão Livre só é gramatical em italiano (28 a), e não em francês (28 b) fato que a leva a concluir que esse tipo de inversão é típica de línguas de sujeito nulo (pro-drop) como o italiano e não em línguas de sujeito pleno, como o francês.

Conforme análise da IE de Kayne \& Pollock (2001), Belletti assume que a ordem VS pode ser obtida por dois processos diferentes: (i) através do movimento de vestígios de IP por Inversão Estilística, em que o sujeito é deslocado para fora da sentença, na periferia esquerda, e o vestígio que fica em IP é posteriormente movido para uma posição ainda mais alta na periferia esquerda; ou (ii) através do movimento do verbo sobre o sujeito por Inversão Livre. Desta forma, Inversão Estilística e Inversão Livre consistiriam em assumir que o sujeito pósverbal é alto na Inversão Estilística, mas não o é na Inversão Livre. A Inversão Livre seria um fenômeno interno à sentença. De maneira geral, a autora adota a hipótese restritiva de que o movimento de vestígios deve ser limitado aos casos em que haja uma entonação que leve a interpretar a inversão como sendo estilística. 
Belletti (2002) assume, portanto, uma periferia dentro de IP. Esta periferia seria paralela à periferia esquerda externa da sentença, e estaria disponível justamente para casos como a Inversão Livre do Sujeito que gera uma ordem VS em línguas de sujeito nulo.

A autora retoma a discussão de Rizzi (1997) de que as interrogativas - WH são incompatíveis com a focalização da periferia esquerda e de que a má-formação desse tipo de sentença seria explicada pelo fato de pronomes WH subirem para a Spec Foco na periferia esquerda, e, sendo esta posição única, não pode conter nem frontalização contrastiva e nem elementos WH. Da mesma forma, ela mostra que também nas declarativas a focalização envolve apenas um constituinte por sentença, não apresentando a característica da recursividade, portanto:

(29) * A GIANNI MARIA ho presentato

AO GIANNI MARIA foi apresentada.

Esta impossibilidade existe pelo fato de haver apenas uma posição de foco na periferia esquerda. Do mesmo modo, Belletti verifica que a focalização da periferia esquerda também não é compatível com a focalização interna à sentença. Observe a impossibilidade de se ter um foco contrastivo da periferia esquerda e o objeto direto em (30 a), e um sujeito pós-verbal em (30 b) interpretada como foco de informação nova:

(30) a * A GIANNI ho regalato un libro

A GIANNI deu um livro

b * UM LIBRO há letto Gianni

UM LIVRO deu Gianni 
Portanto, a partir das proposições de Belletti teríamos a seguinte grade estrutural (simplificada) da sentença ${ }^{40}$, enfatizando a periferia de IP:

\section{Estrutura (31)}

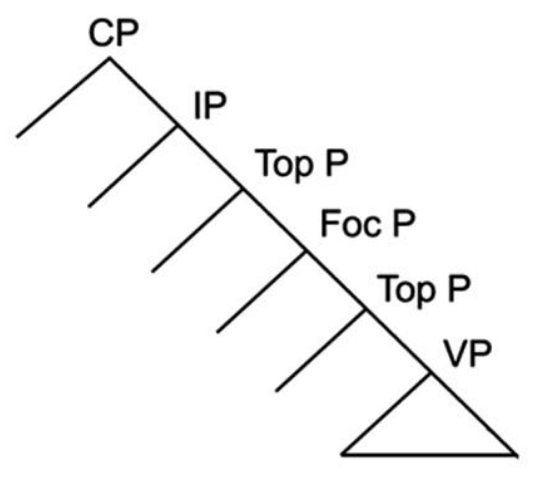

As evidências apresentadas indicam que a periferia abaixo de IP é rica em disponibilidade de posições. Essas posições parecem estar estreitamente associadas ao discurso e com as relações de Foco e Tópico paralelas às mesmas posições disponíveis na periferia externa (esquerda) da sentença.

Assumimos com Belletti a existência da projeção "baixa” de Tópico e Foco que estaria alocada dentro da estrutura da sentença. Essa periferia dará conta de acomodar algumas posições em que encontramos PPs, Locs e LocPs que, apesar de estarem movidos, apresentam-se em posições mais baixas que a periferia de CP, conforme "as pistas" dadas pela posição do verbo e do sujeito.

Mostraremos com esta pesquisa que, do português quatrocentista para o atual, perdemos tanto o Top baixo da periferia esquerda de $\mathrm{CP}$, quanto as posições da periferia baixa. Esse dado parece acompanhar o fato de o PB estar deixando de ser uma língua prodrop para se tornar uma língua de sujeito pleno. E, segundo o que mostra Belletti, a IL do sujeito, bem como a explosão de uma periferia de IP, apenas ocorrem em contextos de línguas

\footnotetext{
${ }^{40}$ Nessa estrutura estamos representando apenas as projeções máximas para que se vejam unicamente as categorias funcionais propostas.
} 
pro-drop. De fato, Massagardi Mendes (2004) atestou, a partir do século XIX, somente casos de argumentos preposicionados do verbo pousando na estrutura externa à sentença, na posição de Foco ou Tópico proposta por Rizzi (1997), e não em posições movidas baixas.

\subsection{Considerações finais do capítulo}

Este capítulo traz o arcabouço teórico utilizado como embasamento da tese.

Serviu-nos de pressuposto teórico central o fato de categorias funcionais funcionarem como uma espécie de bússola frente aos princípios e parâmetros da Gramática Universal. Acreditamos que

com um programa de pesquisa que considera os sistemas funcionais como princípio orientador, os estudos lingüísticos podem alcançar um alto poder descritivo $e$ explanatório das mudanças gramaticais... (Oliveira, 2001) ${ }^{41}$

Na seção de abertura (2.1), apresentamos as duas principais estacas que sustentam a Gramática Gerativa: os princípios e os parâmetros. Os princípios consistem das propriedades intrínsecas a todas as línguas naturais, e os parâmetros atuam na marcação de valores positivos ou negativos de cada princípio. O falante que, geneticamente dispõe de uma Gramática Universal contendo princípios universais, recebe o input de uma dada Língua-E, a partir da qual passará a decodificar seus parâmetros até o momento em que obtém dados suficientes para gerar os discursos de sua gramática particular (Língua-I). Explicamos que é devido à fixação dos valores destes parâmetros que se dá a variação entre as línguas. A

\footnotetext{
${ }^{41}$ Oliveira (2001) tece essa consideração no momento em que propõe um programa de estudos para o então Projeto Para a História do Português Brasileiro (hoje Projeto Caipira), que tomasse os nódulos funcionais como norte para as frentes temáticas.
} 
mudança dentro de uma língua em particular acontece no momento em que os falantes interpretam diferentemente os dados.

Partindo do pressuposto de que as categorias funcionais são o lugar da variação lingüístico-paramétrica, a seção (2.2), dedicada a sumarizar essas categorias, contemplou desde o histórico de projeções tão básicas como CP e IP, até os estudos que as expandiram para projeções tão diversas como AGRS, AGRO, TP, NEGP, e outros. Destacamos a relevância dos estudos do $\mathrm{CP}$ que apontaram para o traço + ou - WH de Comp a partir do verbo que seleciona a sentença encaixada, bem como o estatuto desta última, se adjetiva, se adverbial, completiva.

Nas seções subseqüentes (2.3) e (2.4) retomamos as propostas de Martins (1994). Em (2.3) foram abordadas as projeções de AgrS e AgrO, que, segundo a autora, tinham a capacidade de selecionar especificadores múltiplos, i.e. podiam abrigar ao mesmo tempo sujeito e objeto, fato que explica o scrambling do objeto e a interpolação de constituintes. O estudo destes fenômenos mostrou-se importante já que encontramos Locs e PPs interpolados entre clítico e verbo. Martins (op.cit.) afirma que a interpolação acontece justamente em contextos de próclise obrigatória, dentre os quais está a oração encaixada (sentença-alvo desta pesquisa). A autora acrescenta que a próclise se dá em línguas cujos traços-V(erbo) de $\sum$ são fracos, ou seja, nestas, o alçamento do verbo para $\sum$ não se dá na sintaxe visível, mas apenas em forma lógica, discussão que fizemos em (2.4).

Resenhamos as proposições de Martins sem, no entanto, termos que assumí-las integralmente. Assumimos, sim, que a interpolação acontece em contextos de sentenças encaixadas, mas sem adotarmos categorias como AgrS, AgrO, ou mesmo $\sum$. Interessa-nos particularmente a estrutura sentencial proposta por Martins, na qual o clítico faz fronteiras com constituintes frontalizados (quando à sua direita) e interpolados (quando entre ele e o 
verbo). Esta estrutura é retomada no capítulo dedicado ao pouso do PP/Loc/LocPP (vide cap.5), quando se descrevem as sentenças com a presença de clítico.

As seções (2.5) e (2.6) são especialmente importantes por trazerem as propostas que de fato aplicaremos: a proposta de uma periferia externa da sentença (em CP) que alocaria as projeções de Foco e Tópico (Rizzi, 1997); e a proposta de um IP desmembrado numa periferia interna à sentença disponibilizando posições de Top e Foco (Belletti, 2002) mais baixas que as anteriores. A partir destas será possível construir o modelo de hierarquia estrutural mínima que das sentenças: CP, TopP, FocP, TopP, IP, TopP, FocP, TopP, VP, DP- projeções que estudaremos no capítulo de análises interpretativas (cap.5):

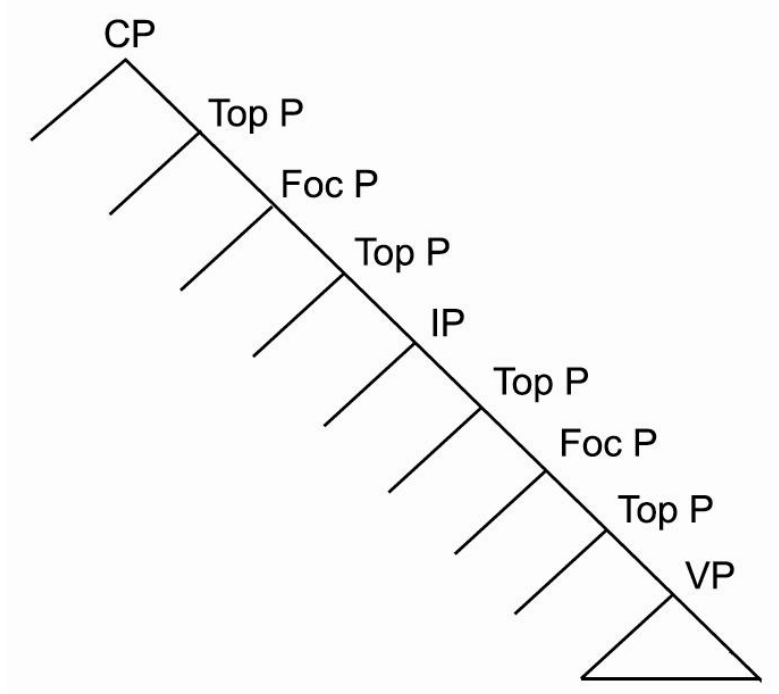

Outro aspecto da seção (2.5) que será relevante é a explicação que Rizzi (1997) dá sobre a incompatibilidade entre foco e operador WH. A partir de testes aplicados em sentenças com a presença de um operador $\mathrm{WH}$, o autor observou que Tópico e WH coocorrem, mas o mesmo não acontece para o caso do foco, fato que o levou a considerar que ambos (foco e WH) ocupam a mesma posição.

Por fim, na seção (2.6) mostramos o estudo exaustivo das estruturas SV que levou Belletti a propor a periferia interna a IP. Foi importante entender como a pesquisadora chegou à sua proposta. Ela mostra que construções de Inversão Livre do Sujeito (IL), que apenas ocorrem em línguas de sujeito nulo, diferem-se estruturalmente das Inversões Estilísticas (IE). 
As estilísticas são, para ela, fruto do discurso e envolvem movimento para a periferia esquerda, mas as livres ocorreriam numa periferia interna à sentença. Não utilizaremos a distinção IE/IL, contudo faremos uso das projeções funcionais propostas, que, conforme mostraremos no capítulo (5) são as hospedeiras das construções que estudamos.

No próximo capítulo fazemos rápida revisão do que a literatura aborda sobre o a existência, história e movimento de Locs e PPs. 


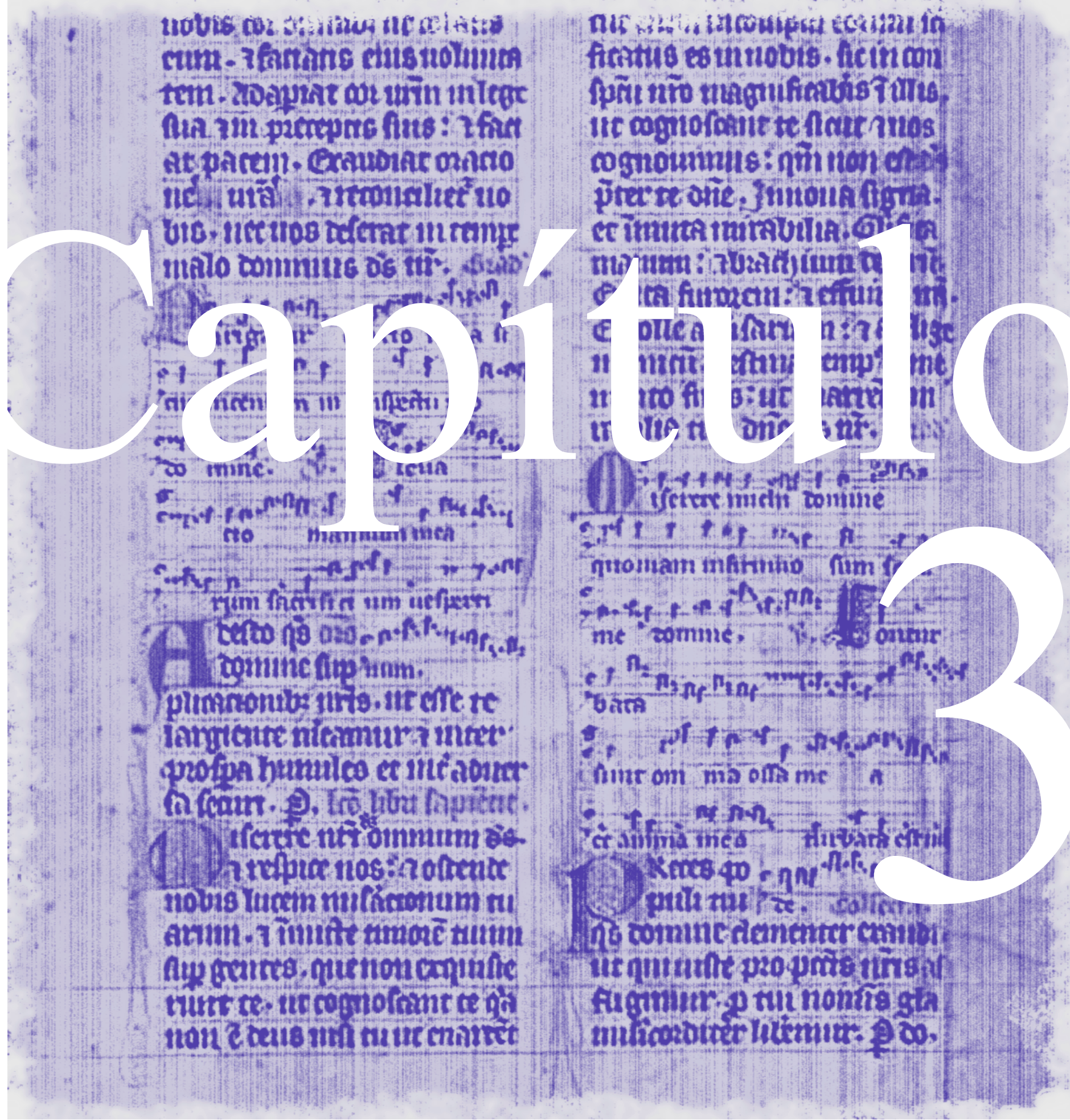




\title{
3. MOVIMENTO DO LOC E DO PP:
}

\author{
REVISÃO DA LITERATURA
}

$\mathrm{N}$

este capítulo apresentamos trabalhos que se dedicaram a tratar direta ou indiretamente dos PPs e dos locativos. Abrimos o capítulo em (3.1) com a pesquisa de Massagardi Mendes (2004) que analisou o movimento de PPs em estruturas encaixadas do séc. XIX-XXI, e que foi fundamental para nortear os primeiros passos desta pesquisa. O trabalho de Muidine (2000), resenhado na seção (3.2), analisa os pronomes locativos-partitivos $h i$ e ende no português dos sécs.XIII-XVI (PM). Em (3.3) apresenta-se a tese de Moraes de Castilho (2005) sobre o redobramento sintático pronominal, também no PM, pesquisa da qual destacamos a duplicação de um locativo por um PP. Finalmente, em (3.4), trazemos a pesquisa desenvolvida em Namiut (2003) sobre os constituintes interpoláveis na passagem do Português Medieval para o Português Clássico (PC)- os PPs estão entre eles.

\subsection{Movimento de PPs nas sentenças encaixadas do século XIX}

Em Massagardi Mendes (2004) analisamos o movimento de PPs (1) em oposição à posição canônica in situ (2).

(1) Quem della lhe der noticia certera (SP 1828) 
(2) Quem lhe der noticia certera della.

Computamos 20,2\% de casos de movimento no corpus formado de anúncios ${ }^{42}$, cartas de leitores e de redatores publicados nos jornais do século XIX, além de peças teatrais pertencentes ao mesmo período. Os resultados do séc.XIX foram confrontados com a análise de uma amostra do século XXI.

No século XXI, não foram computados casos de movimento de PPs argumentais. Os casos apenas residuais de PPs movidos tinham todos função de adjunto. Vimos que os PPs chegaram ao PB contemporâneo com a tendência de não mais serem encontrados em posição movida, salvo em contextos mais específicos ${ }^{43}$.

O que percebemos, de fato, é que a função sintática exercida pelo PP se correlacionava com sua posição de ancoragem na sentença, e talvez essa seria uma das explicações para sua mudança de comportamento. Os PPs argumentais apresentariam-se sempre in situ, enquanto os PPs com função de adjunto, ainda que residuais, registariam-se especificamente fronteados.

Para verificar sua posição estrutural, tivemos que observar se o movimento do PP constituía um caso de elemento interpolado ${ }^{44}$ ou se era resultado de uma topicalização ou uma focalização, e para isso baseamo-nos na proposta de Martins (1994), segundo a qual o clítico marca a fronteira entre constituintes topicalizados ou focalizados e constituintes interpolados. $\mathrm{O}$ PP movido seria um constituinte interpolado se estivesse à direita do clítico, ou seja, entre o clítico e o verbo e topicalizado se estivesse à esquerda do clítico, conforme esquema abaixo:

\footnotetext{
${ }^{42}$ BERLINCK, R. \& GUEDES, M. (2000). E os preços eram commodos: cartas e anúncios em jornais do séc.XIX.

${ }^{43}$ Não esclarecemos aqui em que contextos os PPs ocorrem movidos no PB, por se tratar de questões discursivas que não são o objetivo deste trabalho.

44 Lembramos que o fenômeno da interpolação foi abordado no capítulo (2), na seção destinada a apresentar a proposta de Martins (1994), e neste capítulo a questão será retomada em (3.4) que aborda o trabalho de Namiut (2003) que mostra que no PM, a interpolação de vários constituintes era um fenômeno muito recorrente, mas que na passagem para o PC, passa a especializar-se, restringindo seus contextos à interpolação apenas da negação, construção atestada até o séc.XIX.
} 
Comp - Tópico (ou adjunto frásico) - foco - clítico - XPs interpolados - verbo

Os resultados da análise dos dados do século XIX mostraram que o PP movido ocorria invariavelmente à esquerda do clítico e não à direita. Ficou então descartada a hipótese de que esse PP seria um elemento interpolado.

Restou observar se o PP movido, à esquerda do clítico, ocupava a posição de tópico ou foco da sentença. Para essa discussão, servimo-nos de Rizzi (1997). O autor propõe que foco e operador Wh ocupam a mesma posição estrutural. Portanto, a presença de um elemento $W h$ na sentença inibe a presença de um elemento focal. A incompatibilidade verificada entre OP (operador) Wh e Foco não é observada entre OP Wh e Tópico, pois estes dois elementos não ocupam a mesma posição. Logo, o elemento deslocado, na presença de um OP Wh, tem função de Tópico.

A não identificação de PPs argumentais movidos em estruturas interrogativas nos levou a inferir que o PP movido ocupava nos séculos XIX a XXI a posição de foco. Não se tratava de foco com valor contrastivo, mas sim com a idéia "singularizadora ou identificadora", como propõe Groppi (1998). Em outras palavras, o PP movido ocuparia a função de foco com a característica de identificar, particularizar e não de estabelecer contrastes. Essa análise se coadunava com a presença de PPs movidos no gênero anúncios, que procuravam indicar, particularizar a entidade de que se falava.

Esse trabalho foi, portanto, importante, por ter sido o único da literatura a tratar especificamente do movimento de PPs em estruturas encaixadas. Muito embora tenha utilizado corpora dos sécs.XIX-XXI, apontou direções para que estudássemos as mesmas construções, mas agora no português quatrocentista. Afinal, se o movimento de PPs não se mostrou muito produtivo já no português oitocentista, e praticamente nulo no PB contemporâneo, estaríamos assistindo a um gráfico de declínio brusco no movimento desses 
constituintes. A pergunta seria: em períodos anteriores, os índices de movimento de PPs teriam sido altos e passariam por um processo de desuso, ou teriam sido sempre baixos? Os resultados da quantificação serão apresentados no capítulo 4. Para esta pesquisa, além de estarmos investigando o movimento dos PPs, os estamos comparando com pronomes locativos e com pronomes locativos preposicionados. Já que adotamos o pressuposto de que o uso dos pronomes locativos seria anterior ao dos PPs, e que, estes teriam substituídos aqueles, será necessário conhecermos a natureza dos "antecessores" dos PPs antes de partirmos para as comparações entre eles.

Na seção a seguir, retomamos estudos sobre os pronomes $h i$ e ende, pronomes que, em tese, mantêm estreitas ligações com os sintagmas preposicionados.

\subsection{Pronomes $h i$ e en(de): classificação tripartida pronominal e posição}

Muidine (2000) e Moraes de Castilho (2005) observaram a concorrência dos pronomes hi e ende com os PPs, bem como testemunharam o desaparecimento dos primeiros em favor dos últimos.

O locativo y (hi ou $i$ ) deriva do latim ibi e hic e o partitivo ende deriva da forma latina inde. Said Ali (1971), Nunes (1975), Silva Dias (1933) e Huber (1986) consideram-nos advérbios pronominais. No entanto, o uso anafórico desses elementos levou Mattos e Silva (1989), Teyssier (1990) e Muidine (2000) a considerá-los pronomes. Esta seção apresenta justamente o estudo de Muidine (2000) no qual a autora os considera como pronomes anafóricos fracos, seguindo a classificação tripartida pronominal de Cardinaletti e Starke (1999).

Muidine estuda os pronomes hi e ende no português dos séculos XIII-XVI, tomando como fonte de estudo documentos notariais de caráter jurídico editados por Martins (1994). 
Observa que estas formas não eram muito freqüentes e que co-ocorriam com formas fortes como os PPs.

A autora tem por finalidade identificar a classificação categorial de hi e ende e, com base em Cardinaletti e Starke (1999) da classificação tripartida das formas pronominais (pronomes fracos, clíticos e pronomes fortes), hipotetiza que esses elementos pronominais fossem, no Português Medieval, pronomes fracos. Nesse sentido, o desaparecimento de hi e ende faria parte de um processo mais alargado de eliminação dos pronomes fracos (entre eles, os pronomes possessivos átonos ${ }^{45}$ ) da gramática portuguesa.

De acordo com C \& S (op.cit), do ponto de vista sintático, a diferença entre os pronomes fortes e fracos está no fato de que os fortes, mas não os fracos, podem ser modificados, coordenados, focalizados contrastivamente, ou usados isoladamente. Para C \& S, do ponto de vista semântico, os pronomes fortes ${ }^{46}$ são portadores de referência, ao passo que os fracos ${ }^{47}$ precisam recuperar sua referência que só é dada no discurso, são, portanto, anafóricos. Essa característica semântica a que C \& S referem-se de pronomes fortes portarem referência semântica e os fracos não, será retomada nas análises descritivas e servirão como uma das explicações para a mobilidade dos constituintes "fortes" e "fracos" na sentença.

C \& S consideram que os pronomes fracos não são núcleos $(\mathrm{X})$, mas sim projeções máximas (XP), mesmo se deficientes em relação aos DPs e os pronomes fortes que são essencialmente projeções máximas plenas. Os pronomes fracos projetariam uma estrutura mais reduzida (mais fraca) que a estrutura das projeções plenas.

\footnotetext{
${ }^{45}$ Os pronomes possessivos átonos da gramática portuguesa antiga eram $m a$, $t a$, sa, relacionados com as primeiras, segundas e terceiras pessoas, respectivamente. Cardinaletti e Starke (1999) mostram que as línguas preferem alguns elementos a outros, caso é das línguas germânicas que parecem ter preferido os pronomes fracos, e as românicas que, ao longo da história, parecem ter preferido os pronomes clíticos.

${ }^{46}$ Segundo Cardinaletti e Starke (1999) os pronomes fortes teriam comportamento correspondente aos sintagmas nominais (NPs), e estariam associados ao traço [+humano].

${ }^{47}$ Cardinaletti \& Starke (op.cit) identificam também como pronomes fracos aqueles que possuem forma morfologicamente reduzida, e se caracterizam geralmente por um movimento para uma posição adjacente ao verbo. Estariam associados ao traço [-humano].
} 
O aspecto fonológico também é considerado pelos autores. O caráter tônico dos pronomes fracos explica a possibilidade de ocorrerem não-adjacentes ao verbo. Se são tônicos, não precisam de "hospedeiros" fonológicos e possibilitam a ocorrência de constituintes entre eles e o verbo. O aspecto fonológico (tonicidade) aproxima pronomes fortes e fracos, mas os distancia dos clíticos. A atonicidade dos clíticos obriga-os a adjungirem-se ao verbo (X) em posição pós-verbal. A posição pré-verbal e a não-adjacência ocorrem apenas em presença de elementos proclisadores.

Para observar se hi e ende se comportavam como pronomes fortes ou fracos, Muidine lançou mão do teste da coordenação e da referencialidade. No que concerne à coordenação, observou que apenas os pronomes fortes, mas não os fracos, aparecem nesse contexto (veja PPs grifados) :

(3) (...) nas sobredictas Casas cõ seu quintãal (...) e façã dellas e e ellas todo Aquello que lhys Aprouguer (Lx, 1383, p.360)

Quanto à referencialidade, os pronomes $h i$ e ende são sempre anafóricos. Esses dois fatos empíricos sugerem que esses pronomes não podem ser caracterizados como fortes. Resta saber se são fracos ou se pertencem à categoria dos clíticos.

Há dois aspectos que distinguem os clíticos dos pronomes fracos, segundo a proposta de Cardinaletti (1999):

1) Possibilidade de os pronomes fracos poderem ocorrer em primeira posição, tanto em línguas V2 como o alemão, como em línguas de lei Tobler-Mussafia, como é o caso das românicas antigas. 
2) A possibilidade de os pronomes fracos ocorrerem não-adjacentes ao verbo.

Tomando como referência Martins (1994), Muidine comparou a posição de $h i$ e ende com a dos clíticos, seja em relação à posição do verbo seja em relação à adjacência/não adjacência dos mesmos relativamente ao verbo em dois tipos de estruturas oracionais: orações dependentes e não-dependentes ${ }^{48}$.

A descrição contrastiva da colocação dos pronomes $h i$ e ende relativamente à posição dos clíticos acusativos e dativos mostrou comportamentos semelhantes, mas também comportamentos diferentes.

$\mathrm{Na}$ presença de advérbios proclisadores e orações com foco marcado, clíticos e pronomes $h i$ e ende igualmente se encontram em posição pré-verbal. As fronteiras de distinção são: (i) ocorrência do pronome ende em posição inicial de frase exemplificado em (4); (ii) na presença da negação os clíticos aparecem em posição proclítica em qualquer tipo de oração, ao passo que hi e ende podem ocorrer em posição pós-verbal em qualquer oração como em (5); (iii) nas orações independentes, clíticos apresentam variação próclise/ênclise, $i$ e ende ocorrem sempre em posição pós-verbal, veja $h j$ sublinhado em (6).

(4) E eu Pedro dominguiz publico tabeliõn. De Lixboa rogado das partes de suso ditas á éesto presente ffoy $\widetilde{\text { ede }}$ duas cartas partidas per a.b.c. cõ mha mão propria escreuy $(\mathrm{Lx}, 1297, \mathrm{p} .125)^{49}$

\footnotetext{
${ }^{48}$ Muidine (2000) adota esta nomenclatura (dependentes/não dependentes) de Martins (1994). São consideradas dependentes as subordinadas, e não-dependentes as frases simples, orações principais e orações coordenadas (não-disjuntivas).

${ }^{49}$ Para que o exemplo faça sentido, deve-se entender que há um ponto antes de e $\sim$ de, de acordo com os modelos desse tipo de escritura.
} 


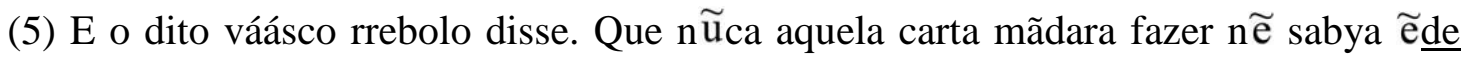
parte (Lx, 1294, p.103)

(6) E no dia que mi aduserẽ nõ custe rẽ ao Moesteiro. E mãdu hi ũnu Cal (sic) de valõzelu en que mora Johã Petri (NO, 1268, p.4)

Diferentemente dos clíticos que apenas interpolam em contextos de próclise obrigatória $^{50}$, hi e ende aparecem em posições não adjacentes e em posição pré-verbal em contextos em que a anteposição não é obrigatória. Além disso, em posição pós-verbal, $h i$ e ende não são restritos pela adjacência ao verbo. Essas observações levam Muidine a concluir que os pronomes $h i$ e ende não apresentam comportamento sintático típico de pronomes clíticos. São pronomes fracos.

O fato é que esses pronomes fracos concorriam com as formas fortes, encabeçadas pelas preposições em e de, e no século XV foram substituídos pelas formas fortes (sintagmas preposicionados). Ende desapareceu do sistema e $h i$ se inseriu no sistema adverbial como forma forte aí.

Observe-se que através desses exemplos, a autora não quer mostrar a tendência ao movimento ou permanência in situ de Locs e PPs, mas sim mostrar a alternância entre Locs e PPs, i.e , entre formas fracas e fortes, ou, ainda, que Locs do tipo hi e ende podem ocorrer em posições em que os clíticos não ocorrem, fato que justamente os distingue dos clíticos e os classifica como pronomes fracos.

A autora mostra que a co-ocorrência das formas fortes e fracas se dá em vários contextos, entre os quais, salientamos as orações não-dependentes afirmativas e negativas e as dependentes.

\footnotetext{
${ }^{50}$ Considera-se como contextos de interpolação obrigatória as subordinadas finitas e infinitivas introduzidas por preposição, ou as independentes com a presença de um advérbio proclisador ou sintagma focalizado.
} 


\section{ORAÇÕES NÃO-DEPENDENTES "NEUTRAS"51}

(7) e eu Pedro gõncaluiz tabalõ. Publico de. Celorico de Basto foy presente e scripuj esta carta e pusj y meu sinal que tal est (NO, 1277, p.16)

O exemplo acima é extraído do fechamento de um documento. A autora ressalta que embora $h i$ seja bastante freqüente nestes enquadramentos sintáticos, os sintagmas preposicionados (8) e locativos de outra natureza (9) é que aparecem com maior freqüência nesse contexto:

(8) E eu ffernam vaaz tabeliam del Rej nosso Senhor em a dicta cidade e seu termo que este estormento screpuj e por verdade em elle meu pprobico sinal fiz (NO, 1504, p.628)

(9) E eu Gonçallo gonçallvez tabelljõ geeral Del rrey Antre doíro e mjnho que esta carta per mãdado da dita Maria gonçallvez há escreuy E aqui meu sjnal fiz (NO, 1408, p.388)

Note-se que em (7) y ocorre em posposição ao verbo, mas suas formas concorrentes em $(8,9)$ ocorrem em anteposição.

Quanto a ende, sua presença se dá em posição pós-verbal (posição típica dos clíticos):

\footnotetext{
${ }^{51}$ Muidine adota a terminologia de orações não-dependentes "neutras" para as orações principais ou coordenadas que se caracterizam pela ausência de condicionadores de posicionamento dos clíticos. Seriam esses condicionadores: negação, alguns advérbios, etc.
} 
(10) E desta protestaçõ. Per o dito Martim queixada pidyo ende A m $\widetilde{\jmath}$ vic ẽte martĩiz Tabelliõ hũu strumẽto (Lx, 1299, p.135)

\section{ORAÇÕES NAO-DEPENDENTES NEGATIVAS}

Nas orações não-dependentes negativas, tanto o pronome fraco ( $h j$ em 11) como o forte (eneles em 12) ocorrem em posição pós-verbal, ou seja, em posição em que o clítico não ocorre (dada a presença do elemento negativo que é atrativo):

(11) que Caualejros nẽ outros homéés que nõ son en derejto n $\widetilde{e}$ en possisson de naturas das Ejgreias oú de Moesteiros que nõ faça mal nas Ejgreias nẽ nos Moesteiros. $\mathrm{N} \widetilde{\mathrm{e}}$ pousen hj ata que demãden per derejto (NO, séc.XIII-XIV, p.151)

(12) mãda nosso Senhor el Rej que os Monesteiros das Ordẽes de Cistel do seu Rejno seiã enparadas. E negũu nõ pouse eneles assi come padrões e herdejros (NO, séc.XIIIXIV, p.155)

O mesmo acontece com ende (13), que pode alternar com um PP (14) nos mesmos contextos:

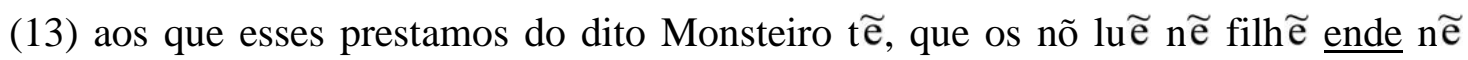

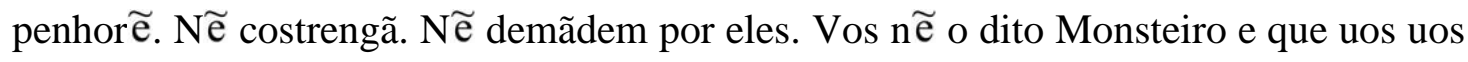
abrã deles mãão (NO, 1342, p.208) 


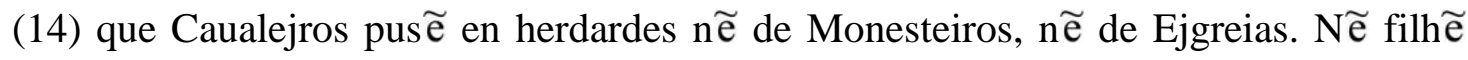
delas ]herdardes] pã nẽ vinho (NO, séc.XIII-XIV, p.150)

\section{ORAÇÕES DEPENDENTES}

Quanto às orações dependentes, Muidine observa variação entre $h i$, PP e zero entre os séculos XIII e XIV. A partir dos séculos XV e XVI, hi (15) não ocorre mais nestes $\operatorname{contextos}^{52}$. A referência espacial anteriormente identificada no discurso passa a ser retomada apenas pelo PP (16):

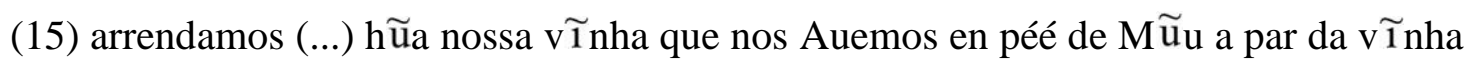
dos ffreyres póla meyadade do ffruyto que deus y der. Der. (Lx, 1305, p.262)

(16) Cem Moyos de SaL na eira da dita Marinha qual o Deus ẽ ela der (Lx, 1394, p.371)

$H i$ e ende ocorrem em posição pré-verbal (15) ou pós-verbal (17):

(17) nossos capôs que auemos em Recarey per nome o cãpo dauole e o outro cãpo do ual de uydy. Os quaes cãpo (sic) trage Martim Dominguez que chama das eyras em hưu nosso casal que de nos trage. Per tal preyto e per tal cõdi[co] que uos façades hy casas é toda bẽfeytoria que poderdes fazer. E que dedes ende em cada ũu ano a Mart $\widetilde{1}$ dominguiz e a ssa moler I maravedi em toda as uida deles (NO, 1279, p.29)

\footnotetext{
${ }^{52}$ No caso da Crônica do Conde D.Pedro de Menezes hi continua a ocorrer em variação com PPs nestes contextos.
} 
A autora observa que a ocorrência de ende começa a rarear bastante cedo. A partir dos séculos XIII e XIV começa a deixar de ser registrada, gradativamente, até desaparecer completamente a partir do século XV. Os exemplos a seguir mostram a variação entre ende (18) e PP (19). Ambos ocorrem em posição pós-verbal:

(18) E disse o dito scudeiro que o dito Priol por ssi e por seu cõuento fosse aa dita Qu ĩãa da Ramada e aas herdades dela e que aquelo que achassem que era do dito

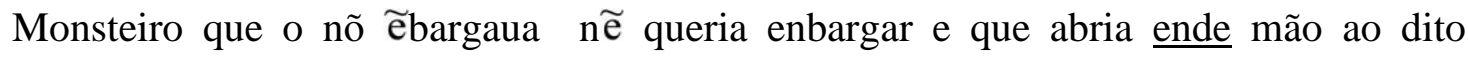
Monsteiro E o dito Priol disse que lhj prazia ende e lho Garcia muyto (NO, 1339, p.202)

(19) (...) esses prestamos (...) n $\widetilde{\mathrm{e}}$ demãdem por eles. Vos n $\widetilde{\mathrm{e}}$ o dito Monsteiro e que vos abra deles mãão (NO, 1342, p.208)

Muidine conclui que os pronomes hi e ende encontravam-se em franca disputa com formas fortes como os sintagmas preposicionados e as categorias vazias (pronome nulo) desde o século XIII, mas, apesar de seu elevado número de ocorrências, já se apresentavam em desvantagem em relação às suas formas concorrentes. Essa desvantagem foi gradualmente aumentado, até que, a partir do século XV hi passou a ocorrer com menor frequiência, e ende deixou de ocorrer ${ }^{53}$.

\footnotetext{
${ }^{53}$ Embora Muidine afirme que tanto hi como ende já apresentariam desvantagem em relação aos PPs desde o séc.XIII, e que ende deixa de ocorrer no séc.XV, há registros de documentos muito fartos em ocorrência de ende (que é ainda mais raro que hi) como é o caso do Flos Sanctorum, séc.XIV (informação cedida pela Profa. Dra. Ilza Ribeiro na ocasião do exame de qualificação desta tese, em Outubro de 2008). De fato, na Crônica do Conde D. Pedro de Menezes, não encontramos ocorrências de ende, talvez por pertencer ao século XV. Ainda assim, assumimos a declaração de Muidine, sobre a desvantagem dos locativos em relação aos PPs; a substituição dos locativos por estes só se verifica, segundo ela, a partir do séc.XV.
} 
O quadro abaixo sumariza as características dos dados encontrados pela pesquisadora:

\section{Quadro1: Posições de hi, ende e PPs}

\begin{tabular}{|c|c|}
\hline Formas fracas & Formas fortes \\
\hline \multicolumn{2}{|c|}{ Orações não-dependentes afirmativas } \\
\hline $\mathrm{V}+$ hi/ende & em elle $\mathrm{OV}$ \\
\hline \multicolumn{2}{|c|}{ Orações não-dependentes negativas } \\
\hline $\begin{array}{l}\mathrm{Neg} \mathrm{V}+\mathrm{hi} / \mathrm{ende} \\
\text { Orações dependentes }\end{array}$ & Neg V + nelles/delles \\
\hline $\begin{array}{l}\text { Que S hi V } \\
\text { Que S V hi }\end{array}$ & $\begin{array}{l}\text { que S nella V } \\
\text { que cl V delles }\end{array}$ \\
\hline
\end{tabular}

Não há diferença na posição de pronomes fracos e fortes nas orações não-dependentes negativas. As duas formas pronominais ocupam posição pós-verbal.

Nas orações dependentes, $h i$ ocorre antes ou depois do V e o PP locativo vem anteposto ao verbo; o ende, por sua vez, ocorre simplesmente após o verbo e a sua contraparte preposicionada também é posposta ao verbo.

À diferença das orações não-dependentes afirmativas, em que a posição do pronome fraco diverge da posição do pronome forte, nos demais tipos de oração há tendência a que as duas formas pronominais ocupem a posição posposta ao verbo. Mesmo nos casos em que as formas pronominais antecedem o verbo, elas se acham separadas do elemento $q u$ - pelo sujeito. Esses dados sugerem a inexistência de fronteamento de PPs argumentais e de pronomes fracos nos dados da autora.

Da pesquisa de Muidine, além de assumirmos o pressuposto de que o uso dos pronomes hi e ende tenha sido suplantado pelo uso dos PPs a partir dos sécs.XV/XVI, estamos adotando para hi/ende a classificação de pronomes fracos, em contraste com 
pronomes clíticos e fortes. Por vezes, também os chamaremos de pronomes locativos ou pronomes anafóricos, já que estamos os considerando: pronomes fracos, locativos, e anafóricos. Será adotada, ainda, a visão de Cardinaletti e Starke (1999) de que os pronomes fortes portam referência semântica no discurso, mas, em contraste, os pronomes fracos (entre eles $h i$ e ende) por não portarem referência, são anafóricos.

Na visão de Moraes de Castilho (2005), que figurará como alvo da próxima seção, $h i$ e ende seriam pronomes clíticos, visão que não adotamos. No entanto, a pesquisa da autora ganha importância no trabalho, na medida em que estuda o redobro pronominal de um locativo do tipo hi por um PP. Seu trabalho mostra três estágios da ocorrência de locativos e PPs: um primeiro em que Locs e PPs aparecem redobrados e em correferência, outro em que ambos se dissociam, e um último em que a sentença dispõe de apenas um deles. Esse histórico parece sinalizar a posição de PPs e Locs, reafirmando a relevância de compará-los.

\subsection{Locativos e PPs no Processo de Redobramento Sintático no Português Medieval}

Apoiada em Kato (1999), Moraes Castilho (2005) assume que os pronomes podem ser fortes e fracos e ambos podem compor o redobramento sintático pronominal, caracterizado pela correspondência entre pronome fraco e pronome tônico e pela sua inserção numa mesma fronteira sintática. Em suma, no redobramento pronominal o pronome fraco duplica o tônico (preposicionado ou não).

A autora estuda o locativo $h i^{54}$ (para a autora um clítico) que redobra um PP nucleado pela preposição em. Para a autora, esse redobro constitui um tipo especial de minioração (small clause, conforme Stowell 1985), tratando-se de uma oração equativa, cujo predicado é

\footnotetext{
54 Para alguns autores hispânicos, essa partícula seria resultado da fusão de dois advérbios latinos: lat.ibi "ali"> port. $i$ e lat.hic "aqui" > port. $i$, que tem o sentido de "aqui/aí/ali. Ibi teria passado por uma alteração, tendo perdido sua consoante b, passando à forma ii. Da crase de duas vogais surge o hi. Moraes de Castilho propõe que hic e ibi conviviam no romance português mas exibiam estruturas diferentes. Ela considera hic como a
} 
uma preposição e o sujeito, o pronome $h i$ :

\section{[SC/PP hi [PP]}

Diferentemente da autora, que considera $h i$ um pronome clítico e [hiPP] uma minioração, estaremos considerando hi como pronome fraco e [hiPP] como um redobro associado ou estrutura composta do tipo [pronome fraco $+\mathrm{PP}]^{55}$.

Manifestando-se primordialmente numa estrutura redobrada, o locativo $h \mathrm{i}$ aos poucos se liberta dessa estrutura e passa a se manifestar como locativo simples. A autora aponta três etapas de modificação ${ }^{56}$ :

(i) Etapa A-predomínio da estrutura original (EO, trata-se do redobro [hi $\mathrm{PP}]$ ). $\mathrm{O}$ composto $\left[\right.$ hiPP] aparece em adjunção ao verbo ${ }^{57}$;

(ii) Etapa B- predominância da estrutura dissociada (ED). O pronome fraco $h i$ passa a funcionar como complemento do verbo e o PP em adjunção ao verbo.

(iii) Etapa C- estrutura simplificada (ES): o pronome fraco hi ou o PP aparecem isoladamente como complemento do verbo. Nesta etapa tem-se o desaparecimento de $h i$.

forma tônica, e $h i$ como a átona. Hic, como tônico fazia parte de um núcleo funcional DP e não aparecia em construções de redobro; $h i$, por sua vez, é apontado pela autora como um clítico que fazia parte de uma de um composto [hiPP], podendo aparecer em sua forma simples, ou redobrada.

${ }^{55}$ Não estamos considerando o redobro associado como uma minioração, já que não é o objetivo deste trabalho propor uma estrutura sintática para essa estrutura, mas sim entender o desaparecimento de $h i$ e a permanência de PPs a partir dessas construções redobradas.

${ }^{56}$ Moraes de Castilho (2005:127) esclarece, em seu trabalho, que não está considerando "etapa" como necessariamente uma sucessão cronológica, mas como uma "determinada gramática da classe em exame, que convive com outras gramáticas numa mesma sincronia, mudando apenas a freqüência de seu uso".

${ }^{57}$ A autora destaca que a estrutura dessa etapa era a mais antiga e a menos documentada de todas (Moraes de Castilho 2005:129). Realmente, em nosso corpus essa estrutura foi bem pouco documentada, como mostraremos no próximo capítulo. 
A autora mostra que, na estrutura original/ETAPA A, em caso de orações independentes, $h i$ colocava-se à direita do verbo. Na presença de nome quantificado ou advérbio, $h i$ se posicionava à direita destes. Já nos caso das dependentes, a EO (estrutura original) colocava-se à direita do verbo (20) ou do complementizador (21):

(20) E então o filho que andava i na nave ouvio aquela palavra que sa ${ }^{58}$ madre dissera. $\left(\right.$ XIII LVL 49”28) ${ }^{59}$

$$
[\mathrm{CP} \text { que }[\mathrm{IP} \mathrm{V}[\mathrm{hiPP}]]]^{60}
$$

(21) e a todolos outros que y en esse moesteyro a Deus seruẽ e seruirã (XIII:1299 HPG 214: 3)

$$
\text { [CP que [hiPP] xV]] }
$$

Observe que em (20) [hiPP] é complemento do V; em (21) [hiPP] é adjunto sentencial. Não se observa o fronteamento de PPs argumentais.

Na ETAPA B, a etapa da estrutura dissociada, assistimos à perda da adjacência estrita pronome fraco/constituinte redobrado. $\mathrm{Hi}$ se agrega ao verbo como seu complemento, e o PP continua como adjunto e se move pela sentença.

Para essa etapa, a autora destaca três mudanças em relação à estrutura original: uma, em que $h i$ aparece imediatamente antes ou depois do verbo ${ }^{61}$, e o PP deslocado à periferia

\footnotetext{
${ }^{58}$ No Português Antigo, sa constituía-se na $3^{\mathrm{a}}$ pessoa do singular do quadro de pronomes possessivos átonos.

${ }^{59}$ Nos exemplos desta seção, pronomes locativos e PPs foram grifados. No original da autora, locativos e PPs aparecem negritados e os verbos, grifados.

60 Nesta seção, fazemos uma representação simplificada da estrutura das sentenças através de colchetes que aparecem abaixo delas, assim como este que representa a sentença (20). Observe-se que apenas estão sendo explicitadas as projeções máximas e relevantes para o tema. A finalidade é visualizar a posição de locativos e PPs.

${ }^{61}$ Como Moraes de Castilho considera o locativo $h i$ como um pronome clítico, quando se refere à posição de $h i$ como anteposta ou posposta ao verbo, ela fala em $h i$ proclítico ou enclítico ao verbo, respectivamente. Já que não adotamos a classificação de $h i$ (ou qualquer outro locativo) como um pronome clítico, não utilizamos, conseqüentemente, a terminologia próclise/ênclise para rotular sua posição. Estamos considerando os pronomes
} 
esquerda ou à direita da sentença; outra, em que o vínculo entre $h i$ e o verbo propiciam uma descontigüidade entre o locativo e o PP e o conseqüente aparecimento de itens lexicais entre eles; e uma última mudança em que $h i$ é elidido e o PP, agora sozinho, torna-se complemento do verbo.

Para explicar a primeira mudança da etapa B relatada no parágrafo anterior, a autora passa a chamá-la de estrutura deslocada, já que o PP aparece anteposto ao pronome $h i$ e este se torna o complemento do verbo, ficando posposto ao verbo numa estrutura deslocada do tipo 1 , e anteposto ao verbo numa estrutura deslocada do tipo 2.

Na estrutura deslocada do tipo 1, em que o pronome fraco aparece posposto ao verbo, o PP adjunto a esse mesmo verbo e gerado à sua direita, se deslocaria para a esquerda da sentença e passaria a ocupar na sentença uma posição que, conforme considera a autora, poderia ser mais alta mais alta que CP (como em 22), que seria a de TopP, como mostra o exemplo (23):

(22) Mas quando tu fores livre, destrue este castelo e quantos $\underline{i}$ son fora as donzelas que en presom jazem i (XIII SG 349: 26)

[CP que PP [ IP V hi]]

(23) no paaço do mosteyro de Sam Saluador de Bayram (...) estando hy a senhor donna Líjjanor do Rego (XV:1484 HPG 267:4)

[TopP PP [CP (que) [ IP Vhi]]

locativos como pronomes fracos, na linha de Muidine (2000), fazendo uso apenas de termos como anteposição ou posposição destes pronomes ao verbo. 
Observe que (22) é exemplo de fronteamento do PP para a esfera de CP. O locativo e o PP têm distribuição diferente. Para Moraes de Castilho, PP é adjunto. Os elementos fronteados são geralmente adjuntos e não argumentos.

$\mathrm{Na}$ estrutura deslocada do tipo 2 , em que o pronome fraco se antepõe ao verbo, também como seu complemento, o PP adjunto ao verbo se deslocaria para uma posição à esquerda da sentença, conforme hipótese da autora, mas a grande diferença entre a anterior e esta seria a posição do pronome locativo.

(24) E en Cistel, u verdade soia/sempre morar, disserom-me que nom/ morava $\underline{i}$ avia gran sazon. [XIII CEM 115:17]

PP....[CP que [ IP VhiV]]

(25) Em Castel Rodrigo, ningun requero que pan e uino hy aduxer, non dé portadgo. [XIII FCR 118:22]

PP...[CP que [ IP hiV]]

A segunda mudança da etapa B deu origem ao que se chamou de estrutura descontínua $^{62}$, já que $h i$ aparece posposto ou anteposto ao verbo e o PP aparece dissociado do pronome, surgindo itens lexicais entre eles.

A estrutura descontínua do tipo 1 caracteriza-se por o pronome fraco aparecer depois do verbo e se separar de seu PP que permanece à sua direita, aparecendo itens lexicais entre eles. Veja em (26) e (27) o pronome fraco e o PP em negrito:

(26) ...que se meteria i com seu senhor na barca [XIII SG 463:12]

[CP que [IP V hi X PP]]

\footnotetext{
${ }^{62}$ Moraes de Castilho (2005:135) relata que a estrutura descontínua é bem documentada e bem freqüente em todo o PM.
} 
(27) ...e dizem que nõ ha hy mais de hũa no mundo. [XIV CGE2 108:17] [CP que [IP V hi X PP]]

Já na estrutura descontínua do tipo 2, o pronome fraco, enquanto complemento do verbo se apresenta anteposto ao mesmo, e o PP continua em sua posição de adjunto ao verbo à sua direita. Nesta estrutura, o verbo fica situado exatamente entre o pronome e o PP, e literalmente separa locativo e PP, tornando-os descontínuos:

(28) e...malos omnes que y ouere em aldeã; ;.. [XIII FCR 114:23]

[CP que [IP hi V PP]

(29) e meadade de todo pam que y lauorardes na eyra [XIV:1321 HGP 77:20] [CP que [ IP hi V PP]

A terceira mudança, estrutura elíptica, traz a elipse do pronome fraco e o PP é reanalisado como argumento do verbo, posicionando-se tanto à direita como à esquerda do verbo. Depois disso, a estrutura reduplicada foi se tornando simplificada, com um dos elementos transformado numa categoria vazia:

(30) Rogo-vos que nom vades em esta demanda (...) mas sei verdadeiramente que, se i vai, que fará tam gram dapno nos cavalleiros que aqui som, que todo seu linhagem nom nos poderá cobrar (XIII SG 19:31)

$$
\begin{aligned}
& {[\mathrm{CP} \text { que }[\mathrm{IP} \text { V PP }]} \\
& {[\mathrm{CP} \text { Que }[\mathrm{IP} \text { i/aqui + V ] }}
\end{aligned}
$$


(31) E depois que foram no paaço,... [XIII SG 22:4]

[CP que [IP V PP]

Na ETAPA C, etapa da estrutura simplificada, o pronome $h i$ já aparece sozinho se torna uma flexão locativa do verbo, até desembocar em seu desaparecimento.

No trabalho da pesquisadora, o levantamento de várias ocorrências do tipo v.estar+ hi PP, v.ser+ hi PP, v.haver + hiPP, verbo jazer + hiPP mostra que "esse locativo abriu caminho à formação da perífrase de gerúndio pegando uma carona no processo de gramaticalização de estar (pag.143)"

Abaixo, apresentamos o quadro que adaptamos de Moraes de Castilho (2005: 125) para tornar mais claras as etapas de colocação de [hiPP] explanadas pela autora. Para simplificar a visualização, o espaço do quadro (2) referente à Etapa A encontra-se em lilás, a Etapa B aparece em verde, e a Etapa C em azul: 
Quadro 2: Etapas de mudança do locativo hi e seu redobro, o PP

\begin{tabular}{|c|c|c|c|c|}
\hline Etapa & Estrutura & & Mudança & Categoria \\
\hline $\mathbf{A}$ & $\begin{array}{l}\mathrm{CP} \text { que } \mathrm{V}[\text { hi } \mathrm{PP}] \\
\mathrm{CP} \text { que }[\text { hi } \mathrm{PP}] \mathrm{V}\end{array}$ & $\begin{array}{l}\text { Estrutura } \\
\text { original (EO) }\end{array}$ & $\begin{array}{l}\text { Composto em } \\
\text { adjunção } \\
\text { (primeiramente à } \\
\text { direita) }\end{array}$ & $\begin{array}{l}\mathrm{Hi}=\text { adjunto } \\
\mathrm{PP}=\text { adjunto }\end{array}$ \\
\hline B & $\begin{array}{l}\text { CP que PP V hi } \\
\text { TopP PP CP que V hi }\end{array}$ & deslocada $1(\mathrm{ED})$ & $\begin{array}{c}\text { Perda adjacência } \\
\text { hiPP }\end{array}$ & $\begin{array}{l}\mathrm{Hi}=\text { complemento } \\
\mathrm{PP}=\text { adjunto }\end{array}$ \\
\hline & CP PP que hi $\mathrm{V}$ & deslocada 2 & & \\
\hline & CP que V hi x PP & descontínua 1 & $\mathrm{x}$ entre hi e PP & \\
\hline & CP que hi V PP & descontínua 2 & & \\
\hline & CP que V PP & elíptica & $\begin{array}{l}\text { Elipse de } h i \mathrm{e} \\
\text { reanálise de PP } \\
\text { como argumento }\end{array}$ & $\begin{array}{l}\mathrm{Hi}=\text { elíptico } \\
\mathrm{PP}=\text { complemento }\end{array}$ \\
\hline $\mathrm{C}$ & $\begin{array}{l}\mathrm{CP} \text { que hi } \mathrm{V} \\
\mathrm{CP} \text { que V PP }\end{array}$ & simplificada & $\begin{array}{l}\text { PP sozinho } \\
H i \text { aparece } \\
\text { sozinho até } \\
\text { desaparecer }\end{array}$ & $\begin{array}{l}\mathrm{PP}=\text { complemento } \\
\mathrm{Hi}=\text { flexão locativa }\end{array}$ \\
\hline
\end{tabular}

A partir do quadro vemos que, na ETAPA A, etapa da estrutura original, o redobro [hiPP] funcionava como adjunto do verbo, posicionando-se primeiramente à direita e depois à 
esquerda deste. Havendo a dissociação do redobro na ETAPA B, o PP, enquanto adjunto do verbo, movia-se pela sentença, de maneira a deslocar-se para a periferia esquerda, e, segundo a autora, chega a ocupar a posição de Tópico, para fora da sentença. Depois disto, o PP vai para posições mais baixas da sentença, voltando para $\mathrm{CP}$, e, quando é reanalisado como complemento, deixa de mover-se pela sentença permanecendo in situ, gerando a estrutura simplificada. De modo geral, notamos que são fronteados os adjuntos e não os complementos.

Em síntese, a estrutura redobrada passou por diferentes fases até o desaparecimento total do locativo $h i$ : (i) como pronome redobrado, o [locativo $+\mathrm{PP}]$ funcionava como adjunto do verbo e se posicionava à direita ou esquerda deste; (ii) a desintegração da estrutura redobrada tornava $h$ i complemento do verbo (já que para a autora $h i$ seria cliticizado ao verbo) e se posicionava tanto à esquerda como à direita do mesmo; (iii) com o desaparecimento do locativo, o PP, que redobrava o clítico ${ }^{63} h i$, passou a ser o complemento do verbo; (iv) PP e $h i$ passam a ocorrer isoladamente até que o locativo se desintegre do sistema.

O trabalho de Moraes Castilho deixa entrever uma oscilação na posição de PPs e Locs nas orações dependentes, da qual faremos uso. Assumiremos que, na primeira etapa, quando redobra o locativo, o PP acha-se geralmente posposto ao verbo, na segunda posiciona-se entre $\mathrm{CP}$ e V, e na terceira volta a se posicionar depois do verbo (i.e.in situ). O esquema abaixo resume a proposta:

1) $\mathrm{CP}$ que [hi PP]

2) $\mathrm{CP}$ que PP V hi ou $\mathrm{CP}$ que hi V PP (PP=adjunto/hi=argumento)

3) CP que V PP ou CP que hi V

$\mathrm{PP}=$ argumental que aqui $\mathrm{V}$

$\mathrm{Hi} /$ aqui=argumento

${ }^{63}$ Clítico, na concepção da autora. 
Esses resultados servem como norte para a análise da posição de PPs e Locs (pelo menos dos locativos não-preposicionados) e estão em consonância com a hipótese de Lightfoot (1991) de que a perda morfológica leva à reanálise sintática, neste caso, a perda de $h i$, que realizava a função de complemento do verbo, deixou para seu sucessor PP a função de complemento. ${ }^{64}$

A seguir, na seção (3.4), apresentamos o estudo de Namiut (2003) sobre a mudança no fenômeno da interpolação na passagem do Português Medieval (PM) para o Português Clássico (PC), estudo que dará base teórica e, sobretudo, informação histórica sobre a construção interpolada.

\subsection{A interpolação de constituintes na história do português}

\subsubsection{Os clíticos e a interpolação}

Estudos sobre clítico e interpolação têm demonstrado que o português, comparado a outras línguas românicas, conserva por mais tempo a interpolação, fenômeno que consiste na inserção de um constituinte sentencial entre o clítico e o verbo, gerando construções (cl-x-V). Martins (1994), Paixão de Souza (2000) e Galves (2004) mostram que a perda desta construção na história do português é concomitante à perda da ênclise.

\footnotetext{
${ }^{64}$ Observe que a autora não propõe estruturas para representar a reanálise do PP adjunto em argumento, ela apenas descreve qualitativamente sua mudança de posição e de função. Seu trabalho é de caráter predominantemente descritivo, identificando etapas de gramaticalização, sem, no entanto, apresentar uma proposta formal de tratamento para os dados. Mesmo tendo isso em vista, não pretendemos explicar estruturalmente a reanálise, já que não é este o objetivo do trabalho.
} 
O Português Medieval ${ }^{65}$ (PM/ sécs.XII/XIII-XVI) passa de uma gramática enclítica com interpolação para uma gramática proclítica com interpolação apenas com negação, no Português Clássico (PC/ sécs.XVI-XVIII). A partir de então, reaparece a ênclise e a interpolação da negação sofre brusca queda em orações matrizes.

\subsubsection{Do Português Medieval para o Português Clássico: a mudança dos constituintes interpoláveis}

Namiuti (2003) observa três características do fenômeno da interpolação que distinguem o PM do PC:

(i)

no PM, qualquer constituinte podia aparecer interpolado entre o clítico e o verbo, $c l-x-v$, onde x é o elemento interpolado; já no âmbito do PC, apenas a negação aparece no contexto $c l-x-v$;

(ii) diferentemente do PM, no PC a interpolação em orações matrizes se dá quando o clítico é precedido por um sujeito, um sintagma preposicionado, ou uma conjunção coordenativa "e";

(iii) Cresce no PC a não adjacência entre o elemento proeminente da sentença (o operador que condiciona a próclise obrigatória) e o clítico $(O p \cdot-x-c l)$.

Com base nos dados de textos literários do PC, Corpus anotado do português histórico Tycho Brahe (CTB), Namiut (op.cit.) observa a ocorrência bastante significativa da interpolação de elementos diferentes de "neg" nos textos de autores nascidos no início do século XVI. Em autores mais tardios, a interpolação desses constituintes torna-se obsoleta.

\footnotetext{
${ }^{65}$ Nesta tese, estamos adotando a "etiqueta" de PM- Português Medieval- para o período do português que engloba os sécs.XIII a XVI. Voltamos a enfatizar que entre as terminologias adotadas pela periodização lingüística do português, podemos encontrar a variação entre Português Arcaico (PA) e PM para o mesmo período, conforme a tradição clássico-filológica. Namiut(2003) utiliza a primeira opção (Português Arcaico).
} 
São registrados alguns elementos (encontrados em apenas quatro autores) como: sujeito (pronominal ou forma de tratamento), sintagmas quantificados curtos, alguns advérbios, e os sintagmas preposicionados (normalmente adverbiais ou preposicionais).

Em consonância com o trabalho de Martins (1994), Namiuti observou que a freqüência de interpolação da negação mostra-se sempre nitidamente superior à dos demais constituintes interpoláveis, mantendo-se até o séc. XIX.

Analisando a posição dos clíticos, Martins (op.cit) acabou por traçar a posição dos elementos interpolados, na medida em que observou que era nos contextos de próclise obrigatória do clítico ao verbo que se achava, no Português Medieval, a variação entre a adjacência cl-v e a interpolação, cl-x-v.

Namiuti por outro lado, observou que, juntamente com a perda da interpolação de constituintes do sintagma verbal, surgiram outras possibilidades de interpolar a negação: o "não" interpolado deixou de aparecer apenas em contextos de próclise obrigatória, como nas subordinadas e nas matrizes em que há a presença de constituintes focalizados, e passou a ocorrer em orações matrizes e coordenadas raízes introduzidas por sujeitos pronominais, nominais simples e complexos; sintagmas preposicionais; e/ou precedidas por orações.

As orações relativas, as conjuntivas, e as completivas, são as orações que melhor comportam estruturas com interpolação em português, sobretudo a do tipo $c l-n e g-v$. Há, entretanto, uma diferença em relação à posição do clítico no PM e no PC. No PM o clítico estava, em sua grande maioria, adjacente à conjunção subordinativa, ou a outro operador que condicionasse a próclise; no PC, é a não adjacência entre a conjunção e o clítico que é mais freqüente.

Quanto aos constituintes que antecedem linearmente as estruturas com interpolação, Namiuti observou que, nos dados de Martins, quase todo caso de interpolação apresenta o clítico adjacente ao elemento que introduz a oração ou ao elemento que condiciona a próclise. 
Veja-se o quadro adaptado de Martins que destaca a preferência pela contigüidade do operador subordinativo C e o clítico:

Tabela 1:Posição do clítico nas subordinadas finitas no PM (apud Martins 1994)

\begin{tabular}{|l|l|l|}
\hline C-cl-X-V & 309 & $96 \%$ \\
\hline C-X-cl-V & 12 & $4 \%$ \\
\hline Total & 321 & $100 \%$ \\
\hline
\end{tabular}

Entre as 12 ocorrências de falta de contigüidade entre $\mathrm{C}$ e o clítico, 8 são exemplos de PPs (veja grifos):

(32) "que per esto lhe nõ valhã (Lx, 1440)".

(33) "que pera ysto lhes nõ valhão (Lx, 1440)"

(34) "E com todas as pertenças que aos dictos casaaes lhes dereitam ente pertẽnçe $(\mathrm{NO}, 1522) "$

(35) "E sse pela uẽtura vos algẽ enbargar (Lx, 1294)"

(36) "E sse pela u $\widetilde{\mathrm{e}}_{\text {ntura }}$ vos algue enbargar (Lx, 1296)"

(37) "E sse pela u $\widetilde{e}_{\text {ntura }}$ vos alguen a dicta u $\widetilde{y}_{a}$ enbargar (Lx, 1296)

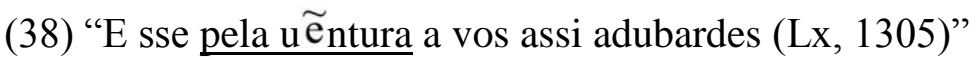

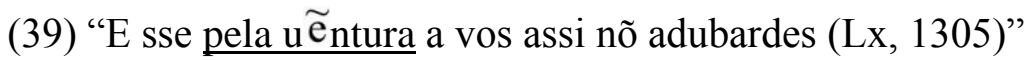

Já no PC, pelo menos nos casos da interpolação da negação, a falta de contigüidade entre o operador e o clítico nas orações subordinadas mostra-se mais freqüente (36\%): 
Tabela 2: A interpolação da negação (apud Namiuti, 2003)

\begin{tabular}{|l|l|l|}
\hline C-cl-neg-V & 650 & $64 \%$ \\
\hline C-X-cl-neg-V & 364 & $36 \%$ \\
\hline Total & 1014 & $100 \%$ \\
\hline
\end{tabular}

Segundo a autora, os constituintes que podiam estar intercalados entre o elemento proclisador e o clítico no PM podiam ser NP, PP ou AP, desde que esses constituintes fossem "não interpoláveis" como tópicos ou adjuntos frásicos, sintagmas preposicionais ou advérbios proclisadores. No entanto, novos elementos passam a ocorrer entre C-cl no PC: sujeitos, sintagmas adverbiais preposicionados e orações, ou até mais de um constituinte. São os PPs:

(40) Entrando depois em casa de seu pai, nem a ela, nem a ele conhecia, polo diferente estado em que a deixara; e, como nesta mudança se lhe não aquietava o coração, foi-se com muita pressa aonde o tinha pôsto. (Lobo-XVI)

(41) Há-de ser animoso e liberal; o primeiro, por que nas matérias que tocarem a guerra, trégua e liga, ou confederação com o seu Príncipe, se não mostre por sua parte acanhado, tímido, nem pusilânimo. (Lobo-XVI)

(42) Para em Calais me não impedirem a saída, nem nas outras cidades até Paris me negarem a entrada por ir de lugar infecto, levo passaporte e recomendação do embaixador de França que está neste reino. (Vieira-cartas-XVII)

Os dados da tabela acima sugerem que a interpolação era muito produtiva nas sentenças encaixadas do Português Clássico, sobretudo nas construções com negação. O quadro quantitativo revelou que as orações subordinadas finitas são as que mais apresentam a interpolação da negação, muito embora os demais contextos também sejam atestados até o 
séc. XIX. A interpolação em contextos de matrizes introduzidas por operador desaparece na segunda metade do séc. XVII.

Os dados de Namiuti chamam a atenção para o fato de que, no PC, a negação pode até mesmo aparecer interpolada em orações não dependentes sem a presença de operador. Além disso, a falta de contigüidade entre o complementador e o clítico em estruturas com interpolação da negação em orações subordinadas, ainda que seja menos freqüente do que a contigüidade, apresenta expressivos $36 \%$, o que leva a autora a propor que a negação e o clítico devam ocupar um mesmo núcleo sintático evidenciando o estatuto de clítico sintático do pronome já no século XVI.

Baseada em Kroch (2003), segundo o qual uma mudança sintática afeta toda uma gramática, e não meramente uma determinada construção, Namiuti conclui que a mudança nos contextos sintáticos da interpolação na passagem do PM para o PC deve estar relacionada com outras mudanças ocorridas na passagem da língua arcaica para a clássica, como é o caso da perda do fronteamento dos complementos verbais (Parcero 1999), constatação esta que também assumimos nesse trabalho.

A autora destaca, ainda, outros fenômenos correlatos: (i) a diminuição da estrutura "cl$\mathrm{x}-\mathrm{V}$ " e o aumento do uso de "C-X-cl-neg-V" e (ii) o aumento da estrutura "C-X-cl-V' que parece acompanhar o crescimento do uso do fronteamento de adjuntos ("XP(adj) V") nos séculos XVI e XVII.

A periodização de Namiut (2003) engloba o PC, classicamente tido pelos estudiosos como um período posterior ao século XVI. Mesmo consistindo de pelo menos dois séculos posteriores ao que analisamos, o trabalho de Namiut é importante porque localiza no português a passagem de uma gramática com interpolação de constituintes diversos para outra com interpolação apenas da negação. A primeira é situada até o século XVI, abrangendo dessa forma, o período quatrocentista (que estudamos) e a segunda, depois deste período. Em 
outras palavras, seu trabalho orienta-nos no sentido de esperarmos que haja interpolação de PPs e Locs no português do século XV, assim como sua queda depois desse período.

\subsection{Considerações finais do capítulo}

Revisamos, neste capítulo, estudos sobre os PPs e os pronomes locativos.

Na primeira seção (3.1), retomamos a pesquisa de Massagardi Mendes (2004) na qual foram analisados os PPs de estruturas encaixadas dos sécs.XIX-XXI. Esse trabalho constatou acentuada queda no movimento dos PPs, fato que sugeriu que, em épocas anteriores, o fronteamento dos PPs pudesse ter sido mais produtivo ou talvez hegemônico. Baseados nessa hipótese, decidimos investigar o fenômeno em outro período do português. Optamos por analisar o português quatrocentista (séc. XV) justamente porque se constitui num período que, de acordo com Galves, Paixão de Souza e Namiut (2006) deixa entrever variações que podem ser interpretadas como competição de gramáticas nos termos de $\operatorname{Kroch}(1989,1994,2001)^{66}$.

A segunda parte assume considerável relevância por tratar dos pronomes hi e ende, que, conforme Muidine (2000) e Moraes de Castilho (2005), teriam sido suplantados pelos PPs. Na seção (3.2), destinada a apresentar Muidine (2000), apresentou-se a proposta de uma classificação tripartida dos pronomes, que se dividem em clíticos, fracos e fortes. Os dados da autora foram submetidos a testes como coordenação, referencialidade, adjacência em relação a verbos e outros. Dentro deste âmbito, os pronomes hi e ende, que se comportaram diferentemente dos pronomes fortes e também dos clíticos, foram tidos como pronomes fracos e anafóricos, visão que passamos a adotar. Do mesmo modo que Cardinaletti e Starke (1999) consideram os pronomes fortes como portadores de referência semântica no discurso, e os

\footnotetext{
${ }^{66}$ Também já havíamos mencionado que o português quatrocentista protagoniza debates concernentes à origem do português que teria sido implantado no Brasil (Moraes de Castilho, 2000). Entretanto, grande parte dos estudiosos considera o português quinhentista, e não o quatrocentista, como a base do português do Brasil, já que foi no séc.XVI que se deu a descoberta/colonização do país.
} 
pronomes fracos como anafóricos que precisam retomar sua referência, estamos assumindo que os PPs sejam formas fortes, e portanto, portadores de referência semântica, e que os Locs sejam as formas fracas e anafóricas, discussão que será retomada no capítulo (4).

Para além de contribuir para a classificação pronominal dos locativos, o trabalho de Muidine torna-se imprescindível por constatar a co-ocorrência de locativos com PPs até o século XV, a substituição dos Locs pelos PPs e desaparecimento de ende a partir deste mesmo período. Tendo em vista que nosso corpus é formado por um texto representativo do século XV, devemos averiguar se de fato existe a alternância no uso de Locs e PPs na Crônica de D.Pedro de Menezes, bem como a existência de ende.

Na seção (3.3) exibimos as etapas por que passou o redobro pronominal do locativo pelo PP, a partir do trabalho de Moraes de Castilho (2005). Vimos que, antes de o PP substituir o locativo hi, esses constituintes conviviam e variavam sua posição.

Num primeiro momento, encontravam-se ambos em correferência dentro de um redobro associado do tipo [hiPP]; em outros momentos, o redobro podia se apresentar deslocado ou dissociado de maneira que se o locativo estava fronteado, o PP estava in situ e vice e versa. Num outro estágio, Locs e PPs já eram encontrados isoladamente até que não mais se registrassem casos de locativos do tipo hi. Estamos assumindo com a autora a hipótese da reanálise sintática do PP. Este seria o percurso de suas funções: quando o PP fazia parte do redobro associado, todo ele funcionava como adjunto; no momento em que se dissocia o pronome fraco se "cliticiza" (nos termos da autora) ao verbo, tornando-se seu complemento, e deixando para o PP a função de adjunto. A diferença é que, nesse momento, o pronome se move, mas não o PP. Apenas quando o PP aparece sozinho, passa a assumir a função de complemento do verbo e deixa de se mover, permanecendo in situ.

Da parte (3.4), sobre a interpolação (Namiut, 2003) admitimos o fato de, na passagem do PM para o PC, a interpolação que ocorria com diversos constituintes (entre eles os PPs) 
passou a ocorrer apenas com a negação, fato que se observa até o séc.XIX. Depois dessa data, a interpolação deixa de ser registrada. Assumimos com Namiut (2003) e Parcero (1999) que a perda da interpolação está correlacionada à perda do fronteamento de complementos verbais na passagem da língua arcaico-medieval para a clássica.

No capítulo que se segue, apresentamos o estudo quantitativo e qualitativo do movimento de PPs, pronomes locativos e pronomes locativos preposicionados que constituem nosso corpus do português quatrocentista. 


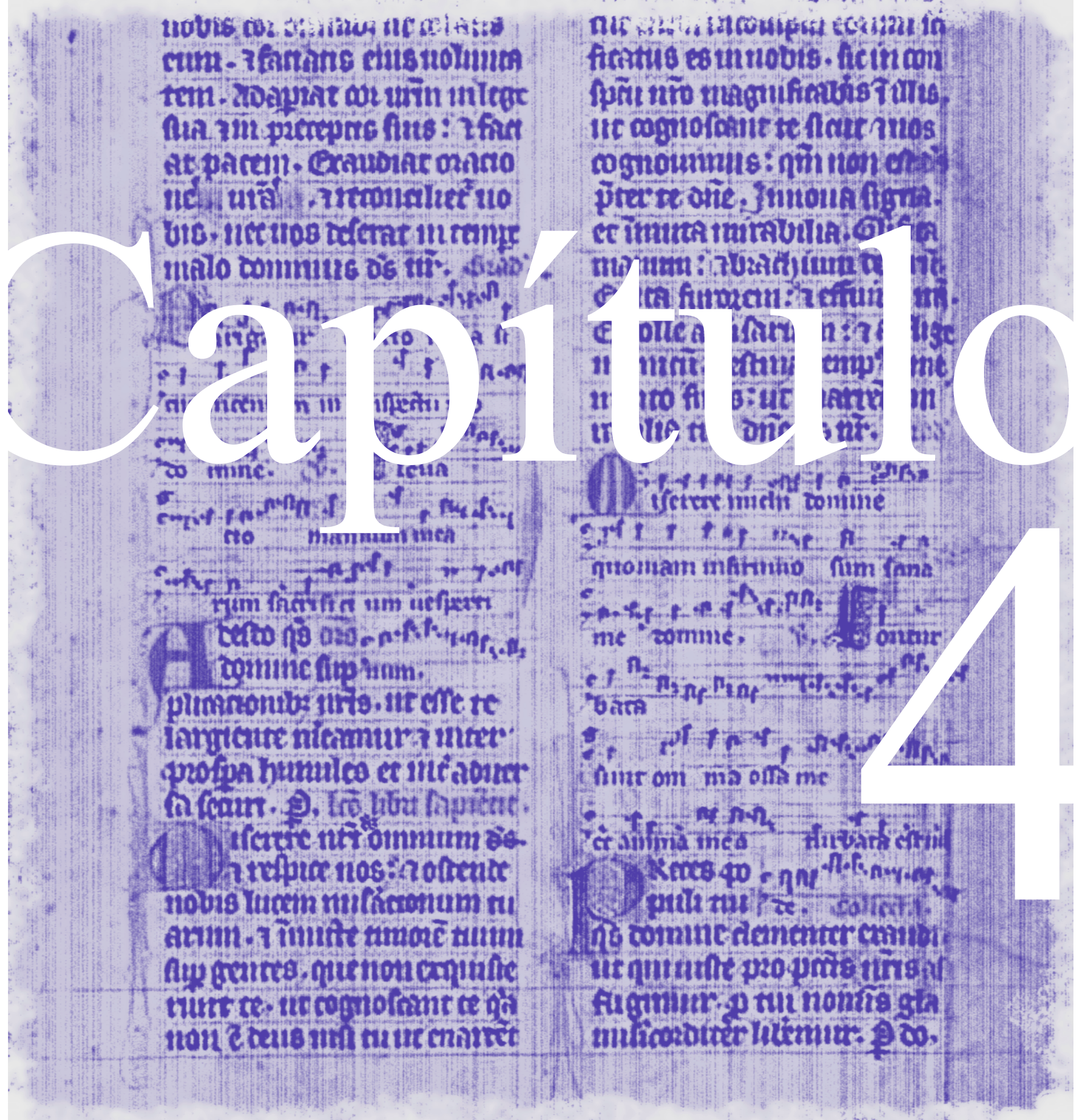




\section{MOVIMENTO DOS LOCATIVOS, PPS E LocPs}

\section{Fatores condicionadores}

$\mathrm{N}$

a análise descritivo-quantitativa dos pronomes locativos e dos PPs, que se segue, apresentamos os cálculos percentuais a que chegamos a partir da análise de 184 ocorrências de cada objeto em estruturas encaixadas. Analisamos também 123

$\operatorname{dados}^{67}$ de locativos preposicionados, extraídos de sentenças independentes e encaixadas. Com isso, pretendemos, neste capítulo, verificar o comportamento dos pronomes locativos (Locs), dos PPs e dos LocPs (locativos preposicionados) no português quatrocentista, comparar os resultados e observar se apresentam a mesma tendência quanto à sua posição na estrutura sentencial.

\subsection{O redobro PP-Loc ou Loc-PP}

Nesta seção, analisamos exemplos em que PPs são retomados por Locs na mesma sentença. O objetivo é comparar os resultados com os de Moraes de Castilho (2005), segundo a qual o processo de redobramento de Loc-PP/PP-Loc apresentou três etapas:

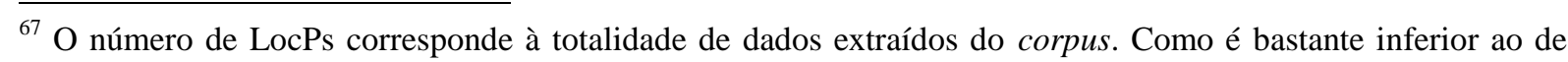
PPs e locativos pronominais, recolhemos dados também de estruturas independentes para que tivéssemos um leque maior de ocorrências que pudessem ser analisadas. 
(i) Etapa A: o PP redobra o locativo, formando a estrutura redobrada [hiPP] que se posiciona posposta ao verbo;

(ii) Etapa B: na dissociação do redobro, o PP assume a função de adjunto e $h i$ a de argumento;

(iii) Etapa C: hi ou PP podem aparecer sozinhos, pospostos ao verbo e com função argumental.

Chamaremos de redobro associado os casos em que PP e Loc se acham em adjacência e correferência e de redobro dissociado os casos em que a adjacência não é observada.

Inicialmente, procuramos verificar a incidência da duplicação do locativo e sua correlação com o posicionamento do pronome locativo e do PP. Foram raras as ocorrências de duplicação, pois não ultrapassaram o número de dez.

Registramos apenas três casos de redobro associado, um em estrutura independente (1) e dois em estrutura encaixada (2 e 3). Os Locs aparecem grifados, e os PPs que os redobram, negritados:

(1) Heram ally daquella cidade (CPM/p.233, 1439)

(2) Ainda que aquy neste vollume achem allg uas cousas (CPM/p.185, 127)

(3) se pervemtura haverá hy amtre vos (CPM/p.460, 1414)

$\mathrm{Na}$ sentença independente o redobro associado aparece posposto ao verbo e nas sentenças encaixadas, temos um exemplo anteposto e um posposto ao verbo. Infere-se daí que o redobro associado poderia ficar in situ ou mover-se ao longo da sentença, diferentemente da proposta de Moraes de Castilho que identifica o redobro associado principalmente após o V. 
A Etapa B, na qual o redobro envolvendo PP e o pronome hi já aparece de forma descontínua, também foi registrada na amostra analisada em sentenças dependentes e independentes (Loc-X-V-PP). Observe Locs grifados e PPs em negrito:

(4) Que ally há nas fralldas dauquella serra (CPM/p.220/1 135)

(5) mouros que ally moravão em hũas poucas de casas (CPM/p.276, 1685$)$

(6) porque aquy nõ há outro capitã ẽ esta terra senão elle (CPM/p.702, 1 740)

(7) matou hũ outro de Cavallo daquelles que ally estava na fromtaria (CPM/p. 697, 1

(8) patrão que ally hera de Cartagenia (CPM/p.445, 161)

(9) vio que dally poderia tyrar ao longo do outeiro (CPM/p.321, 1 462)

(10) e dahy trouxeram a costa de lomgo ate Gibraltar (CPM/p.371, 1665)

Esses resultados sugerem que a duplicação de locativos não é um fenômeno produtivo no português quatrocentista, contrariamente ao que se verificou para o português arcaico anterior aos quatrocentos (Moraes Castilho, 2005). Não é raro, porém, a contigüidade de locativos e PPs não locativos, estruturas que não configuram redobro, como na sentença abaixo:

(11) paremtes e amigos que ally de presemte eram (CPM/p.199/1618)

Verificou-se para todas as ocorrências de redobro dissociado a subida do locativo (bem como de LocP), mas não do PP que se manteve in situ como se, de fato, o locativo assumisse a função de argumento do verbo (haver, morar, estar, ser, tirar, trazer) e o PP a de adjunto. 
Nessa Etapa, observa-se especialização de funções na estrutura descontínua, visto que o PP exerce função de adjunto e $h i$ de argumento (Moraes Castilho 2005), ao passo que na estrutura contínua o bloco Loc-PP, sempre nessa ordem, podia assumir a função de adjunto ou argumento, a depender da seleção do verbo.

A Etapa $C$, estrutura mais freqüente na amostra em análise, representa o fim do redobramento, haja vista que $h i$ e PP aparecem alternadamente. A quebra do redobro leva à especialização da posição de Locs e PPs. Se argumentos, ocorrem em posição canônica; se adjuntos, movem-se na sentença. É o que discutiremos nas próximas seções, em que analisamos os dados de PPs, Locs e LocPs.

Em (4.2) comparamos o movimento de Locs, PPs e LocPs em função de alguns fatores lingüísticos. Na seção (4.3) comparamos Locs e LocPs, e em (4.4) PPs e LocPs, já que os LocPs carregam características de ambos (de Locs e de PPs).

\subsection{Comparando Pronomes Locativos, PPs e Locativos Preposicionados}

Muidine (2000) e Moraes de Castilho (2005) afirmam que os pronomes locativos hilende e os PPs coocorriam no português medieval. O pronome ende deixa de ser registrado do sistema pronominal português no século XV, e no século seguinte o locativo hy se associa à preposição $a$, constituindo a forma forte e dêitica aí, integrando-se, dessa forma, no sistema adverbial locativo. De qualquer modo, a relevância está em admitir que pronomes locativos (com a exceção de ende) e PPs coocorriam no português dos quatrocentos.

Em função do caráter anafórico dos locativos do tipo hy/ende e, como resíduo da estrutura de redobro associado, estamos assumindo que, no redobro dissociado, PPs e pronomes locativos ocupam posições próprias, isto é, haveria especialização de posições para 
as formas ${ }^{68}$. É a partir dessa presunção que, a seguir, passamos a analisar a posição desses elementos,comparativamente. Abaixo acham-se exemplos de dados analisados:

(12) dezemdo que por elles nom falleçeria (CPM/ p.210//1 888)

(13) .. quamdo se fazer poder com bom rresguardo (CPM/p.206/ 1783)

(14) aquella gemta que ally ficava avia grade duvida (CPM/ p.204/ 1750)

(15) comsyderamdo que eu nom vos lexo aquy (CPM/p.206, 1780)

(16) a quall (torre) o comde dally mandara tyrar (CPM/p.591, 1246)

(17) com emtemção de llevar os cristãos comtra lla (CPM/p.242/1 671)

Os percentuais de movimento podem ser vistos no gráfico:

\section{Gráfico 1: Percentual de Movimento dos Locativos, PPs e LocPs ${ }^{69}$}

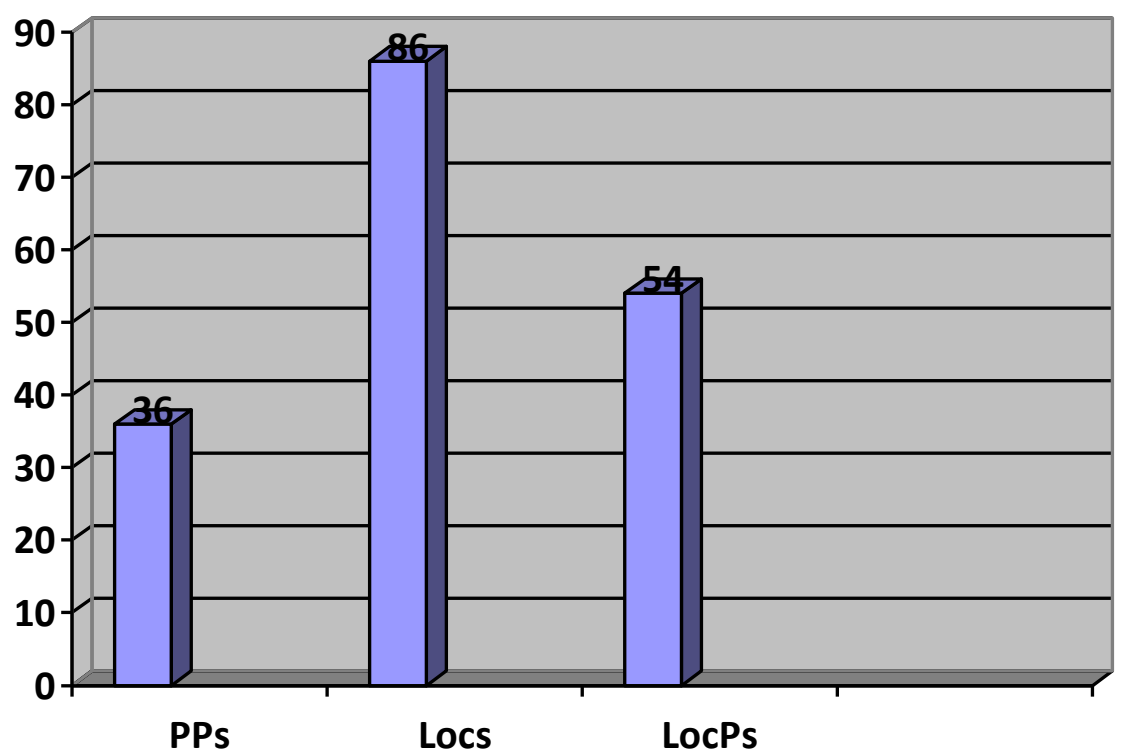

\footnotetext{
${ }^{68}$ Por ser uma categoria híbrida, separamos os locativos preposicionados (LocPs) dos PPs e dos locativos puros para observar se LocP se comporta de maneira semelhante a PPs ou a locativos (Locs).

${ }^{69}$ A versão do gráfico em tabela pode ser conferida no final do capítulo, em Anexos.
} 
O gráfico acima traz os resultados gerais. Os números da tabela mostram que os locativos se comportam diferentemente dos PPs, com $86 \%$ e $36 \%$ de movimento, respectivamente, confirmando a presunção de que locativos e PPs ocupam posições diferenciadas na sentença; locativos tendem à subida e PPs tendem a permanecer in situ. Quanto aos LocPs, parecem ocupar posição intermediária, pois o seu índice de movimento é de 54 pontos percentuais. Não se comporta nem como PP nem como locativo.

A seguir, analisamos alguns fatores que condicionam o movimento dos elementos em análise.

Existe na literatura o consenso de que DPs complexos tendem a não se mover ao longo da sentença (Nascimento, 1984). Para avaliar essa questão, observamos se o peso do NP complemento da preposição interfere no movimento do PP (v.18), distinguindo-se assim do pronome (19), conforme os exemplos:

(18) ate que os tyrasseys da sugeição alhea (CPM/p.190, 1386)

(19) que a elle prazia que ficasse ally por capitão (CPM/ p.197, 559)

Observe que, dada a limitação do corpus histórico que não permite acesso à prosódia, estamos considerando DPs leves aqueles formados por uma preposição mais um pronome (como em a elle) e DPs pesados aqueles formados por uma preposição mais um constituinte complexo diferente de pronome (como em da sujeição alheia).

Observe a variação destes DPs na tabela: 
Tabela 1: Peso do NP Complemento da PreposiçãoX Posição do PP

\begin{tabular}{|l|cr|cc|cc|}
\hline & \multicolumn{2}{|l|}{ PP movido } & \multicolumn{2}{|l|}{ PP in situ } & \multicolumn{2}{|l|}{ Total } \\
& N. & $\%$ & N. & $\%$ & N. & $\%$ \\
& & & & & & \\
\hline DP pesado & 32 & 26,0 & 94 & 74,0 & 126 & 68,0 \\
\hline DP leve & 35 & 60,0 & 23 & 40,0 & 58 & 32,0 \\
\hline Total & 67 & 36,0 & 117 & 64,0 & 184 & 100 \\
& & & & & & \\
\hline
\end{tabular}

Os resultados expressos na tabela acima mostram que DPs pesados retêm o PP hegemonicamente in situ e DPs leves favorecem a subida do PP na estrutura sentencial. Observe que os índices percentuais de LocPs (conf.gráfico1) e de DPs leves movidos são bastante próximos, $54 \%$ e $60 \%$, o que sugere que DPs leves se comportam como os LocPs quanto à posição na estrutura sentencial, na grande maioria dos casos.

Buscamos averiguar se a função de argumento ou de adjunto determina o movimento de PPs, Locativos e LocPs. As sentenças a seguir trazem um exemplo de adjunto e um de complemento, de PPs Locs e LocPs, respectivamente:

(20) porque no outro dia queria hyr dar lenha (CPM/p.295, 1166)

(21) palavras que o comde disse aaquelles (CPM/p.216.1 28)

(22) Mas nos outros que aquy ficamos (CPM/p.211/1 928)

(23) Meu tio que lla morava (CPM/p.223/1 197)

(24) Os mouros que dally escaparõ (CPM/p.280,1 511)

(25) Caa dally foi ferido Gomçallo Velho (CPM/p.473,1 725) 
Tabela 2: Função Sintática do PP/Loc/LocP x Movimento

\begin{tabular}{|c|c|c|c|c|c|c|}
\hline & \multicolumn{2}{|l|}{ PP } & \multicolumn{2}{|l|}{ Loc } & \multicolumn{2}{|l|}{ LocP } \\
\hline & & $\%$ & & $\%$ & N. & $\%$ \\
\hline Adjunto & $48 / 81$ & 59,0 & $146 / 166$ & 87,0 & $54 / 123$ & \\
\hline Argumento & $19 / 103$ & 18,0 & $13 / 18$ & 72,0 & $-I_{-}$ & - \\
\hline Total & $67 / 184$ & & $159 / 184$ & & $123 / 123$ & \\
\hline
\end{tabular}

O movimento de PPs e locativos é mais comumente observado nos casos em que assumem a função de adjuntos. Entretanto, os locativos argumentais tendem a mover-se (72\%), o que não se verifica para os PPs (18\%). Estabelece-se nova diferença: locativos prototipicamente se movem, ou seja, o seu movimento não é condicionado pela função sintática que assumem na sentença. Os PPs, por sua vez, movem-se a depender de sua função sintática, uma vez que PPs na função argumental aparecem quase rigorosamente in situ e PPs na função de adjunto oscilam entre movimento e posição canônica (59\% de movimento). Já os LocPs ocorreram categoricamente na função de adjunto (veja $3^{\text {a }}$ coluna da tabela), mas se distribuem similarmente entre movidos e não, conforme já havia mostrado o gráfico 1. Esses resultados confirmam a tendência à especialização das posições e funções de PPs e Locs.

Em seguida, verificamos se a categoria sintática que seleciona o PP, Loc e LocP influi em suas posições. Veja, nas ocorrências abaixo, um exemplo de verbo e um de nome que selecionam Locs, PPs, e LocPs, nesta seqüência:

(26) paremtes de meu marido que ally moram (CPM/p.277, 1 708)

(27) alldeas que ally são acerca (CPM/p.277, 1 710)

(28) aquelles que ajudarão ao mestre (CPM/p.218, 1 185)

(29) que sabem a fraqueza dos muros (CPM/p.212,1947)

(30) mamdou a allgũs escudeyros seus que se fossem pera laa (CPM/ p.482, 1947) 
(31) os outros melhores daquy derrrador Sam mortos (CPM/ p. 522, 1879)

Tabela 3: Categoria que seleciona PP/Loc/LocP x Movimento

\begin{tabular}{|l|cc|cc|cc|}
\hline & \multicolumn{2}{|c|}{ PP } & \multicolumn{2}{c|}{ Loc } & \multicolumn{2}{c|}{ LocP } \\
\hline & N. & $\%$ & N. & $\%$ & N. & $\%$ \\
\hline Verbo & $60 / 149$ & 40,0 & $157 / 182$ & 86,0 & $63 / 115$ & 54,0 \\
& & & & & & \\
\hline Nome & $07 / 35$ & 20,0 & $02 / 02$ & 100,0 & $03 / 08$ & 38,0 \\
\hline Total & $67 / 184$ & & $159 / 184$ & & $66 / 123$ & \\
\hline
\end{tabular}

Quando a categoria selecionadora do Loc é um verbo, o locativo tende a mover. Não se pode afirmar o mesmo para o PP, ainda que o verbo apresente percentual maior do que o nome no caso do movimento.

A análise subseqüente é resultado do estudo da posição do sujeito e sua relação com a posição de Locs, PPs e LocPs.

Tabela 4: Posição do sujeito ${ }^{70}$ em relação ao verbo X movimento $P P / L o c / L o P$

\begin{tabular}{|l|cc|cc|cc|}
\hline & \multicolumn{2}{|c|}{ PP } & \multicolumn{2}{c|}{ Loc } & \multicolumn{2}{c|}{ LocP } \\
\hline & N. & $\%$ & N. & $\%$ & N. & $\%$ \\
\hline Anteposto V & $11 / 33$ & 33,0 & $18 / 22$ & 81,0 & $08 / 25$ & 32,0 \\
\hline Posposto V & $03 / 07$ & 42,0 & $18 / 18$ & 100,0 & $06 / 09$ & 66,0 \\
\hline Total & $14 / 40$ & & $36 / 40$ & & $14 / 34$ & \\
\hline
\end{tabular}

Da leitura horizontal, observa-se que PPs, Locs e LocPs são preferencialmente movidos quando o sujeito é posposto. O locativo é o único elemento que move produtivamente em contexto de sujeito anteposto (81\%), ainda que no caso de posposição de

\footnotetext{
${ }^{70}$ Aqui tratamos apenas dos casos em que o sujeito é explicitamente realizado, o que explica o baixo número de dados constantes na tabela.
} 
sujeito o movimento do locativo é categórico (100\%): são três casos de verbo transitivo (“deixar") em sentenças adjetivas, um caso de verbo causativo e os demais (14 dados) de verbos inacusativos.

Os verbos transitivos levam à subida dos Locs, mas todos em relativas. A construção relativa é uma maneira de alterar a realização dos argumentos, de forma que se tenha um predicado monoargumental na oração encaixada (Berlinck, 1989). Veja Locs grifados e sujeitos pospostos em negrito:

(32) trezemtos que ally leixou ho imfamte dom hemrique (CPM/p.201,1660)

(33) escudeyros que ally leixara o imfamte dom Amrrique (CPM/p.288,1423)

(34) hera capitão dos que ally leixara o ymfamte dom Amrrique (CPM/p.231, 1410)

(35) armas que ally tinha Joham Preto (CPM/p.542, 1201)

(36) paços que ally mandarõ fazer os rreys amtigos de Fez (CPM/p.233,1439)

Os verbos inacusativos, apesar de monoargumentais, nem sempre favorecem a subida dos Locs para posições altas da sentença, pois estes podem estar em posição pós-verbal, adjacentes ao sujeito posposto.

(37) Porque ally cayam torres forradas d'oliveis pimtados (CPM/p.236,1526)

(38) aymda que hii ouve mouros avisados (CPM/p.682, 1262)

(39) porque ally nõ estaa tall capitão (CPM/p.563, 1730)

(40) que em mui breve foram ally muitos ajumtados (CPM/p.263, 1360) ${ }^{71}$

(41) e seguiu-se que chegou ally h $\widetilde{u}$ hom $\widetilde{e}$ de Cartagenia (CPM/p.369, 1603)

(42) que muitas vezes vieram hy soma de mouros (CPM/p.535, 133)

${ }^{71}$ Note-se que dos exemplos (40-46) os locativos estão pospostos ao verbo, sem no entanto aparecerem na posição canônica (in situ). Estamos considerando canônica apenas os Locs, LocPs e PPs na última posição da sentença. 
(43) acordarom que ficasse logo ally Lopo Vaz (CPM/p.200, 1635)protelados

(44) caa nõ há aqui tall (p.262, 1332)

(45) pera saber per ella se havya hi outra povoraçã (CPM/p.271, 1 703)

(46) que morã hy peça de mouros (CPM/ p. 279, 1758)

Observe-se que o sujeito posposto na maior parte dos exemplos correspondem ao argumento interno de verbos inacusativos e que, nestes casos, o locativo precede o sujeito, como se ocorresse aí uma small clause (SC) ${ }^{72}$ : V ficasse [SC ally Lopo Vaz]; V há [SC aquy tall]; V foram [SC ally muitos ajumtados]; V havia [SC hi outra povoraçã]; V mora [SC hy peça de mouros]; V chegou [SC ally hum homem de Cartagenia]; V vieram [SC hy soma de mouros]. Nos casos de loc movido em contexto de sujeito posposto, a SC é desfeita devido à intermediação do verbo (exs.37-39).

Em contexto de sujeito anteposto (veja sujeitos em negrito), o Loc/LocP movidos ocorrem entre sujeito e verbo; o PP, por sua vez, precede o sujeito:

(47) se estes aquy vivessem (CPM/p.260, 1271)

(48) torre...a quall o comde dally mandara tyrar (CPM/p.591, 1246)

(49) quais aquellas fustas dally partyam (CPM/p.485, 1 1042)

(50) assym como no latym este nome quer dezer "tempus" (CPM/p.173)

(51) que se na sustamçia allgũ erro há (CPM/p.179, 1 150)

(52) que se a vos hũ tall lugar fora filhado (CPM/p. 190, 1382)

Os PPs movem-se também em contexto de verbo inacusativo, com sujeito posposto:

(53) homrra de que a elles nom venha sua parte (CPM/p.177, 1 102)

\footnotetext{
${ }^{72}$ Não se confunda SC com redobro.
} 
(54) e porque no cabo daquelle Valle heram allguãs casas (CPM/p.281,1820)

(55) e seguiu-se que naquelles dias se ajumtarão muitos daquelles juízes $(\mathrm{CPM} / \mathrm{p} .284,1232)$

No que concerne aos LocPs, o sujeito posposto favorece o seu movimento. O exemplo (56) traz o locativo in situ à direita do sujeito posposto; os demais trazem o locativo movido em sentenças com verbo inacusativo. Em (59 e 62), tem-se locativo movido, mas o verbo é intransitivo:

(56) partyo-se o comde dally (CPM/p.349,1121)

(57) E dhy se deriva crônica (CPM/p.173.112)

(58) caa dally foi ferido Gomçallo Velho (CPM/p.473,1725)

(59) E dally pera fundo ate em dereito da guarda dAllvaro Memdez avia de combater Xeber com todollos outros velhos da serra (CPM/ p.470, 1648)

(60) E dally se foy o comde a cidade de Lisboa (CPM/p.582, 128)

(61) porque dally te omde se chama o Porto do Lião foi feita gramde mortymdade de ymfies $(\mathrm{CPM} / \mathrm{p} .650,1482)$

(62) E dally até o mar combatia hũ mouro (CPM/p.470,1659)

Os resultados sugerem que o movimento de Locs, PPs e LocPs independe da posição do sujeito em relação ao verbo. Os dados com sujeito anteposto permitiram observar que PPs, Locs e LocPs ficam entre S e V nestes casos.

Analisamos ainda se o tipo de sentença favorece ou não o movimento de PPs, locativos e LocPs. Abaixo apresentamos os exemplos de sentenças adjetivas, adverbiais e completivas dos PPs, Locs e LocPs (grifados), respectivamente: 
(63) Semdo hom $\widetilde{\mathrm{e}}_{\mathrm{S}}$ que de seu sytio nõ aviamos perfeito conhecimento (CPM/ p.212/1 945)

(64) mamdou que seguysse com a cavallgada (CPM/p.238/1860)

(65) .. quamdo se fazer poder com bom rresguardo (CPM/p.206/ 1783 )

(66) molheres e moços que hii achava (CPM/p.697/1614)

(67) emquamto aquelles vallados e arvoredos ally estevessem (CPM/p.236/1510)

(68) eu creo - disse ele - que aquy nõ están nenhũ (CPM/p.203/1719)

(69) Os mouros que dally escaparõ (CPM/ p.280, 1541)

(70) porque o caminho hera afastado dally $(\mathrm{CPM} / \mathrm{p} .344,114)$

(71) Mas vos vedes que daquy ao mar há hũa legoa (CPM/ p.571, 1918)

Os resultados são expressos no gráfico abaixo:

Gráfico 2: Tipo de Sentença x percentual de Movimento de PP, Loc, e LocP $^{73}$

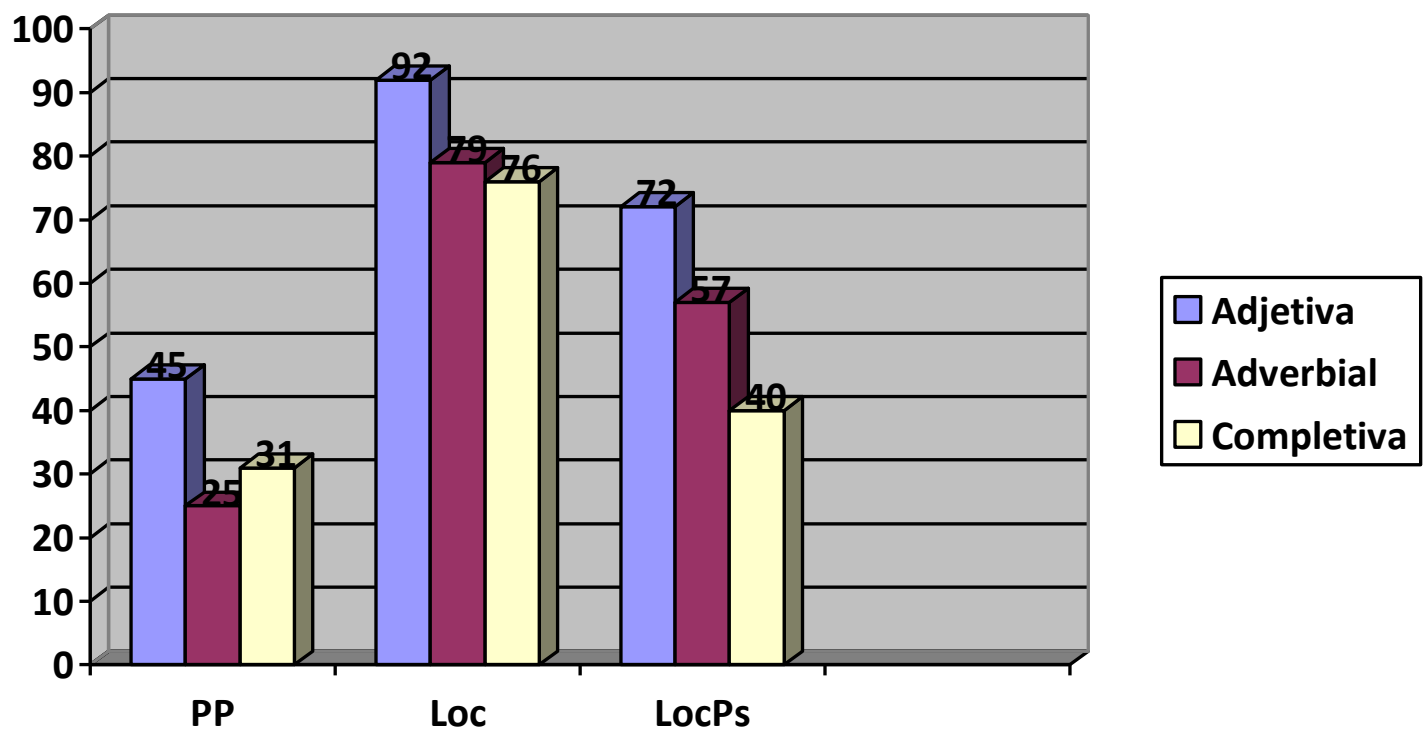

\footnotetext{
${ }^{73}$ Veja tabela correspondente a esse gráfico no anexo 2, ao final do capítulo.
} 
O movimento de locativos é favorecido em todos os tipos de sentenças encaixadas, mas esse favorecimento decresce nas completivas (76,0\%). No caso dos PPs, apenas a sentença adjetiva é ambiente propiciador de seu movimento (45\%), mas mesmo assim não atinge os 50\%; nos demais tipos de sentença encaixada o que se observa é exatamente o oposto, ou seja, o PP é mantido preferencialmente in situ. Quanto aos LocPs, o seu movimento é favorecido nas adjetivas (72\%) e adverbiais (57\%), seguindo o perfil dos Locs, mas nas completivas seguem o padrão dos PPs, ocupando a posição canônica desses elementos, ou seja, ficam in situ.

Como vimos acima, todos os tipos de sentenças encaixadas apresentam predominantemente o locativo movido, mas a completiva com menor intensidade. Talvez a diferença entre adverbiais e relativas de um lado e completivas de outro se deva ao fato de que nas primeiras o Spec de C é ocupado; nas completivas não é projetado. Conjunção adverbial e pronome relativo codificam aspectos circunstanciais e referenciais, respectivamente, ao passo que a conjunção integrante, que encabeça a completiva, tem função exclusiva de introduzir o complemento sentencial selecionado pelo verbo da matriz.

Da análise comparativa de PPs, Locs e LocPs, chegamos às seguintes diferenças:

i). de modo geral, locativos tendem a mover-se; PPs permanecem hegemonicamente in situ se for constituído de DP pesado. Já o DP leve se comporta como os LocPs que alternam entre subida e permanência in situ;

ii). a função sintática do locativo é irrelevante para o seu movimento, muito embora os percentuais subam ligeiramente nos casos de locativos com função adjuntiva; PPs, entretanto, movem-se principalmente quando desempenham a função de adjunto. Todos os LocPs são adjuntos, mas alternam entre subida ou permanência in situ; 
(iii). PPs apresentam maiores percentuais de movimento quando se encontram em contexto de sentenças encaixadas adjetivas; LocPs podem se mover em qualquer tipo de sentença (dependente ou não), porém, dentre as dependentes, há mais casos de subida nas adjetivas. Quanto aos Locs, o seu movimento não é condicionado pelo tipo de sentença, na medida em que o movimento é favorecido em qualquer tipo de sentença.

Em síntese, Locativos movem-se livremente pela estrutura sentencial. Já o movimento dos PPs é fortemente condicionado pela natureza leve do DP, pela função de adjunto e por fazer parte de uma sentença adjetiva. LocPs movem-se com mais facilidade do que os PPs, mas compartilham com estes o favorecimento da subida pelo tipo de sentença.

Conclui-se que, em conformidade ao que se havia previsto no início do capítulo, PPs e locativos se comportam diferentemente, quanto à sua posição na estrutura sentencial. Ressalvando-se o contexto da sentença adjetival, pode-se inferir uma certa especialização da posição de locativos e PPs: os primeiros movem-se; os últimos permanecem in situ. Os LocPs ficam a meio caminho, já que são a mescla de um e de outro.

\subsection{Comparando pronomes locativos e locativos preposicionados}

O estudo mais pontual dos pronomes locativos e dos locativos preposicionados, cujos resultados serão tratados nesta seção, procurou observar três propriedades: (i) qual locativo era mais usado no corpus em análise, (ii) o condicionamento do movimento pelo tipo de locativo e (iii) o condicionamento do movimento pela referencialidade. Seguem-se os exemplos de tipos de locativos (72-75), e locativos preposicionados (76-79), respectivamente:

(72) gemte nobre que ally avia de ficar (CPM/p.205,1754)

(73) e pervemtura que tais hy havia (CPM/p.221,1160)

(74) quanto mais que aquy nom está nenhu tall (CPM/p.261,1298) 
(75) ora vede que gemte mandarey $\underline{\text { la }}$ (CPM/p.261,1301)

(76) porque vio que dally poderya tirar ao lomgo do outeiro (CPM/p.321, 1462)

(77) trato que de hy em diamte ficasse sempre aos rreys de Grada (CPM/p.488, 1 16)

(78) que quamdo daquy party (CPM/ p.700, 1709)

(79) quatro besteyros que abastaram pera laa (CPM/p.242/1671)

Tabela 5: Tipo de Locativo X Movimento

\begin{tabular}{|l|cc|lc|}
\hline & \multicolumn{2}{|c|}{ Loc } & \multicolumn{2}{c|}{ LocP } \\
\hline & N. & $\%$ & N. & $\%$ \\
\hline Ally & $63 / 73$ & 87,0 & $47 / 82$ & 57,0 \\
\hline Hy & $51 / 55$ & 93,0 & $10 / 14$ & 71,0 \\
\hline Aquy & $38 / 48$ & 79,0 & $09 / 16$ & 56,0 \\
\hline Llaa & $07 / 08$ & 88,0 & - & \\
\hline Total & $159 / 184$ & 86,0 & $66 / 123$ & 54,0 \\
\hline
\end{tabular}

De acordo com a tabela acima, o locativo mais produtivo no corpus em estudo é o pronome ally, precedido ou não de preposição; o mais raro é o locativo llaa/la que não apareceu preposicionado. Apesar de o pronome ally ser o mais freqüente, o locativo que prototipicamente parece mover é hy, uma vez que apresentou o altíssimo índice de 93 pontos percentuais nos casos não preposicionados e 71 na condição de LocPs. Aquy classifica-se como o pronome locativo que menos sofre movimento.

Tendo em vista a distribuição acima e o pressuposto de que o pronome hy tinha a função exclusivamente anafórica e que veio a se tornar dêitico a partir do momento em que se transformou em pronome forte aí (Mattos e Silva, 1989; Muidine, 2000 e Moraes de Castilho, 2005), hipotetizamos que o traço anaforicidade poderia ser fator condicionante do movimento dos locativos. 
Já o pronome partitivo do tipo ende não foi encontrado. Na Crônica do Conde D.Pedro de Menezes encontramos apenas PPs e principalmente LocPs desempenhando a função partitiva, fato que nos leva a admitir que já no português quatrocentista (séc.XV), o uso de ende havia sido substituído. De fato, autores como Moraes de Castilho (2005), Muidine (2000), e Teyssier (1990) ${ }^{74}$, encontraram ende apenas até o século XIV.

Para observar se o fator anaforicidade explicaria o maior índice de movimento das formas hi e ally, procedemos à análise da referencialidade dos pronomes. Os constituintes grifados nas sentenças a seguir ilustram um locativo [-REF ou +ANAF] em (80) e um [+REF ou - ANAF $]^{75}$,em (81):

Para reforçar o sentido anafórico de hii, o primeiro exemplo (80), abaixo, é encabeçado por este resumo de capítulo:

Capitolo XII das pallavras que o comde disse aaquelles que com elle ficarom rrepremdemdo-os da tristeza que tinham.(CPM/p.216,1 28, 29)

(80) "Nom diremos por certo que ho comde dom Pedro estava olhamdo o movimento das vellas que faziam sua viag e n e atemdia ao cuydado que aquelles popullares aviam, como muito esforçado cavaleiro e muy Dino de tall encarrego, amdava pellos muros cõ esses fidalgos que hii ficarõ, olhamdo aos lugares per omde devia poer suas guardas e omde compria mais ou menos força de gemte, de guisa que por mimgoa de bõo avisamemto nõ rreçebesse allg ua perda.”(CPM/p.216,1 30-34)

\footnotetext{
${ }^{74}$ Teyssier (1990), tendo observado o comportamento dos pronomes hi e ende nos séculos XIV, XV e XVI, datou o desaparecimento de ende no séc.XV, uma vez que não encontrou uma ocorrência sequer desse pronome na Crônica de D.Pedro de Fernão Lopes. Muidine (2000) registrou a última ocorrência de ende no ano de 1353, i.e. já na segunda metade do séc.XIV. A autora considera que o uso de ende tenha sido superado pelo pronome nulo, no entanto, com esse trabalho mostramos que o uso de ende foi também substituído por PPs e LocPs partitivos.

${ }^{75}$ A etiqueta $[\mathrm{REF}]$ corresponde aos elementos referenciais e [ANAF] aos anafóricos.
} 
Em (81) o rei se justifica aos que não puderam ir à guerra, convencendo-os de proteção e cuidado de sua parte. Este capítulo foi aberto assim:

Capitolo VIII como ell rrey fallou aos fidallgos que ally aviam de ficar. (CPM/ p.204, 1746)

(81) "Soomemte vos amoesto e rrequeiro que todos vossos feitos sempre sejam com todo bõo rregimemto, que Sam cousas que no auto das guerras muitas vezes aproveita,e ho comtrario dana muito empece, caa já ouviriaes, ou pervemtura verieis, muy gramdes esperiemçias de semelhamtes feitos e por ello deveis de tomar muy gramde cuydado de vos s epre muy cautellosamemte meterdes nos perigos, comsyderamdo que eu nom vos lexo aquy tãto por ofemder, como pera defemder bem e que, quamdo se fazer poder com bom resguardo, nõ me desprezará de afzerdes aos ymfies qualquer dano que ser poder e de sayrdes a elles, avemdo primeiro boa segurança que vos possais, com vosso sallvo, delles aproveitar.”(CPM/p.206,1774785)

Buscamos saber se o fato de um pronome locativo (e de um locativo preposicionado) ser portador de maior carga anafórica o impulsionava a migrar para a esquerda de modo a se aproximar de seu referente numa sentença anterior. Partimos do pressuposto de que os pronomes fortes ou os sintagmas lexicais são elementos mais referenciais (+ REF) ${ }^{76}$, sendo, portanto, mais livres e independentes na sentença, dada sua característica semanticamente autônoma. Por outro lado, os pronomes anafóricos/fracos são menos referenciais (- REF)

\footnotetext{
${ }^{76}$ Para Cardinaletti \& Starke (1999), os pronomes se dividem em fortes, fracos e clíticos. Os pronomes fortes são, eles próprios, portadores de referência semântica, e os fracos precisam recuperar sua referência que só é dada no discurso, sendo anafóricos, portanto.
} 
porque sua referência depende de um antecedente sentencial. Em outras palavras, os pronomes (+REF, -ANAF) correspondem semanticamente aos pronomes fortes de Cardinaletti e Starke (1999) e, de acordo com nossa proposição, não necessitam se mover (mas podem se mover); já os pronomes (+ANAF, -REF), que correspondem semanticamente aos pronomes fracos/anafóricos de C \& S, além de consistirem em DPs leves e suscetíveis ao movimento, necessitam mover-se para se aproximarem de seu antecedente. Ressalte-se, porém, que, embora tenhamos adotado o aspecto semântico da proposta de classificação pronominal de C \& S, não assumimos a posição estrutural que propuseram, já que nossos dados mostram que tanto os pronomes fortes $[+\mathrm{REF}]$ quanto os fracos $[-\mathrm{REF}]$ podem se mover para a periferia de CP. ${ }^{77}$

No tocante à referencialidade, constatou-se que são categoricamente [- REF] os pronomes hy, ally e laa. O locativo aquy aparece como o prototípico pronome [+ REF]. De fato, o levantamento das ocorrências de aquy mostra que grande parte destes aparece em contextos situacionais, evidência que reforça a sua interpretação dêitica [-ANAF, +REF], como os exemplos abaixo, todos de discurso direto:

(82) "He verdade-disse elle - que vos nõ estaes aquy soomente pello que a m y pertemçee, mas pella homrra da coroa de vosso rrey e pella vossa propia, pero, porque sobre $\mathrm{m} \sim \mathrm{y}$ pemde tamto o carrego desta cidade como vos bem conheceis, çertamente eu vos agradeço muy muito vosso gramde trabalho e bõas vomtades." (CPM/p.323, $1529-533)$

(83) “- OO, disse elle- nobre fidallgo! Pera vos husardes de vossa nobreza, vos me desviaes soltar llyvrememte s e outra rremdição, sequer por não perderdes o exercício

\footnotetext{
${ }^{77}$ Cardinaletti \& Starke (1999) alocam os pronomes fortes em CP, os fracos em $\sum$ P e os clíticos, na esfera de IP.
} 
da cavalaria, caa pois Aabu, e desy Zaem, e os outros melhores daquy derrador Sam mortos, jaa sabeis que me temdes aquy cada mês." (CPM/p.522,1875-880)

(84) “E sobre todo lhe acreçemta a fortalleza ho socorro dos amigos que tem muy acerca, espiçiallmemte taes como são os beesteiros que jazem desta outra parte da serra, os quaes eu creo que em breve sejam aquy." (CPM/p.566,1820)

Seguem-se os resultados:

\section{Tabela 6: Referencialidade do pronome X Movimento}

\begin{tabular}{|l|ll|ll|}
\hline & \multicolumn{2}{|c|}{ Loc } & \multicolumn{2}{c|}{ LocP } \\
\hline & N. & $\%$ & N. & $\%$ \\
\hline -Referencial & $120 / 134$ & 90,0 & $58 / 108$ & 54,0 \\
\hline +Referencial & $39 / 50$ & 78,0 & $08 / 15$ & 54,0 \\
\hline Total & $159 / 184$ & & $66 / 123$ & \\
\hline
\end{tabular}

Os dados da tabela acima mostram que, no caso dos locativos, o movimento é fortemente favorecido pelo traço anaforicidade, (-referencialidade); já para os LocPs, o traço anaforicidade, não se sobressai como fator condicionante do movimento.

Para observar esta relação com todos os tipos de locativo, cruzamos os números das tabelas tipo de pronome locativo com anaforicidade, cujos resultados podemos contemplar na tabela a seguir: 
Tabela 7: Anaforicidade X Tipo de pronome locativo- percentual de movimento

\begin{tabular}{|c|c|c|c|c|c|c|c|c|c|c|}
\hline & & \multicolumn{2}{|l|}{ HY } & \multicolumn{2}{|c|}{ AQUY } & \multicolumn{2}{|c|}{ ALLY } & \multicolumn{2}{|l|}{ LAA } & TOTAL \\
\hline & & $\mathrm{N}$ & $\%$ & $\mathrm{~N}$ & $\%$ & $\mathrm{~N}$ & $\%$ & $\mathrm{~N}$ & $\%$ & $\mathrm{~N} \quad \%$ \\
\hline \multirow{2}{*}{ +Anafórico } & Loc & $51 / 55$ & 93,0 & - & - & $62 / 73$ & 87,0 & $07 / 08$ & 88,0 & $120 / 134$ \\
\hline & LocP & $10 / 14$ & 71,0 & $02 / 03$ & 67,0 & $46 / 80$ & 58,0 & $\ldots / 11$ & - & $58 / 108$ \\
\hline \multirow{2}{*}{-Anafórico } & Loc & - & - & $38 / 48$ & 79,0 & $01 / 02$ & 50,0 & - & - & $39 / 50$ \\
\hline & LocP & - & - & $07 / 13$ & 54,0 & $01 / 02$ & 50,0 & - & - & $08 / 15$ \\
\hline
\end{tabular}

Da análise do tipo de locativo por anaforicidade, infere-se que são categoricamente [+ANAF] os pronomes hy, ally e laa. O locativo aquy assume geralmente um caráter [ANAF], o que pode explicar o fato de sua taxa de movimento ser inferior à dos locativos anafóricos hy, ally, e laa, que são [+ANAF].

A anaforicidade leva ao movimento na grande maioria dos casos, como é o caso de hy (93\%), ally (87\%) e laa (88\%). O menor movimento dos locativos [-ANAF], a contra senso, leva a inferir que quanto menos anafóricos são os pronomes maior autonomia semântica assumem, e, portanto, maior capacidade de ocupar posições variadas na sentença.

Portanto, contrariamente à proposta de $\mathrm{C} \& \mathrm{~S}$ de que pronomes fortes $[+\mathrm{REF}]$ sobem para a posição mais alta da sentença, os resultados referentes ao movimento dos locativos sugerem que os pronomes fortes são livres para figurarem em diferentes posições na S. Por sua vez, os pronomes fracos, marcados [-REF], tendem a mover-se para a posição mais alta da sentença, ou seja, sofrem uma restrição quanto à flexibilidade posicional, fixando-se em um único lugar.

A diferença entre constituintes [+ANAF, -REF] e [-ANAF, +REF] é sentida, sobretudo, quando se compara Locs e PPs. Os Locs são majoritariamente [+ANAF, -REF], 
enquanto os PPs são categoricamente [+REF, -ANAF]. Conforme foi discutido no início do capítulo, de modo geral, os Locs movem e os PPs ficam in situ. Em outras palavras, constituintes [+ANAF] prototipicamente movem, e [-ANAF] ficam in situ.

Esse comportamento parece correlacionar-se aos princípios A e C da Ligação. O princípio A propõe que os elementos anafóricos estão presos em sua categoria de regência e o princípio $C$ estabelece que uma expressão-R deve estar livre, ou seja, não se vincula a um antecedente, devido à sua autonomia referencial (Chomsky, 1986).

\subsection{Comparando PPs e Locativos Preposicionados}

A análise desta seção privilegia o estudo dos PPs e dos locativos preposicionados (LocPs), procurando evidenciar duas características em comum: o tipo de preposição que encabeça o PP/LocP (4.4.1) e o Caso que desempenham na sentença (4.4.2).

\subsubsection{O núcleo de PP e de LocP na incidência do movimento}

Observemos o comportamento dos PPs e dos LocPs em função do tipo de preposição que os encabeça. Abaixo estão os exemplos de PPs (85-88), e de LocPs (89-93):

(85) ...assynamdo allg ũa cousa que de muitos seja vista....(CPM/ p.186/1301)

(86) quãto mais hua cousa que a todos he tam manyfesta (CPM/p.191/1421)

(87) Camanho vosso regno he e o que nelle há de gemte e de rriqueza (CPM/ p.189/ 1354)

(88) E finallmemte Martym Affomso nunca pôde fazer com hos seus que quisess $\widetilde{\mathrm{e}}$

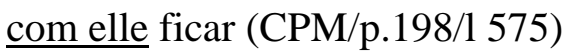

(89) E de hy se tornarão aas fustas (CPM/p.432,1100) 
(90) porque per ally emtemdia emviar o socorro (CPM/p.257,1)

(91) vamos primeiro comtra laa allgua noite (CPM/p.268, 1471)

(92) E esto acabado de dezer encaminharam pera laa (CPM/p.365, 1522)

(93) e como ate aquy nõ temos feita nenhũa cousa... (CPM/p.387, 111)

Tendo em vista o reduzido número de preposições diferentes da preposição “de” que encabeçam o LocP, para compararmos PPs e LocPs opusemos "de" a outras preposições em geral. Os resultados acham-se na tabela a seguir:

\section{Tabela 8: Tipo de preposição X Movimento de PP/LocP}

\begin{tabular}{|l|cc|cc|}
\hline & \multicolumn{2}{|c|}{ PP } & \multicolumn{2}{c|}{ LocP } \\
\hline Preposição & N. & $\%$ & N. & $\%$ \\
& & & & \\
\hline De & $19 / 69$ & 28,0 & $54 / 92$ & 60,0 \\
\hline Outras & $48 / 115$ & 72,0 & $12 / 31$ & 40,0 \\
\hline Total & $67 / 184$ & 38,0 & $66 / 123$ & 54,0 \\
& & & & \\
\hline
\end{tabular}

Observa-se que o movimento do LocP é favorecido quando a preposição que o encabeça é de (60\%), o que não se verifica para os PPs, pois o índice percentual de PPs movidos encabeçados por de é de apenas $28 \%$. Para observar se o movimento de PPs é favorecido por alguma outra preposição ou se o tipo de preposição não é fator condicionante para o movimento de PPs, apresentamos o gráfico a seguir: 
Gráfico 3: Tipo de preposição $X$ percentual de Movimento de $\mathbf{P P}^{78}$

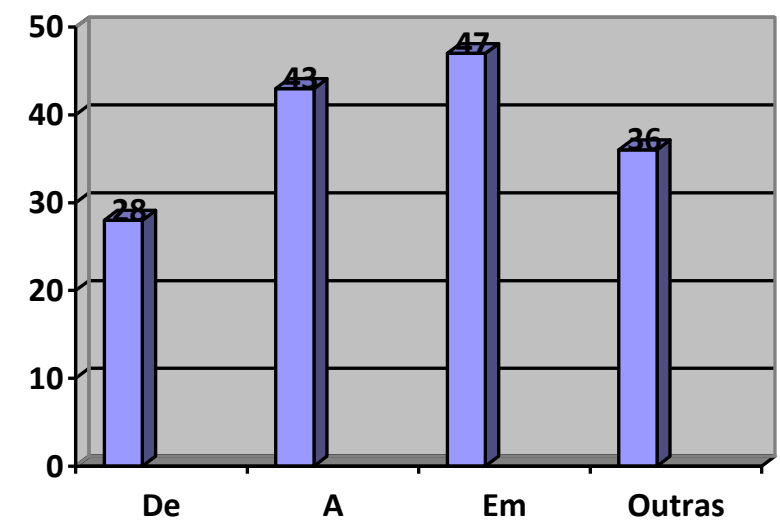

De acordo com o gráfico acima, nenhuma preposição condiciona o movimento do PP e a preposição $d e$, apesar de tradicionalmente introduzir tópicos e apresentar os maiores índices de ocorrência, é justamente a que registra menor incidência de subida de PPs, com apenas 28 pontos percentuais.

Tendo em vista o alto índice de movimento de LocPs encabeçados pela preposição de, cruzamos o tipo de preposição com o tipo de locativo, cujos resultados acham-se na tabela abaixo:

Tabela 9: Tipo de preposição do LocP X Tipo de Locativo: percentual de movimento

\begin{tabular}{|l|cc|cc|cc|cc|}
\hline & \multicolumn{2}{|c|}{ Ally } & \multicolumn{2}{c|}{ Hy } & \multicolumn{2}{c|}{ Aquy } & \multicolumn{2}{c|}{ Laa } \\
\hline & N. & $\%$ & N. & $\%$ & N. & $\%$ & N. & $\%$ \\
& & & & & & & & \\
\hline De & $39 / 68$ & 57,0 & $10 / 12$ & 83,0 & $05 / 12$ & 42,0 & $\ldots-$ & - \\
\hline Outras & $08 / 14$ & 57,0 & $\ldots / 02$ & - & $04 / 04$ & 100,0 & -111 & - \\
\hline Total & $47 / 82$ & 57,0 & $10 / 14$ & 71,0 & $09 / 16$ & 56,0 & -111 & - \\
\hline
\end{tabular}

\footnotetext{
${ }^{78}$ A tabela correspondente ao gráfico 3 encontra-se ao final do capítulo, em anexo.
} 
A combinação da preposição de com os locativos hy e ally gera os maiores índices percentuais de movimento, $83 \%$ e $57 \%$, respectivamente. Observe-se que a combinação de $h y$ com preposição diferente de de não aciona o movimento do LocP, o que sugere que, a preposição de favorece o movimento de locativos anafóricos. De fato, laa, um locativo anafórico, quando precedido de preposição diferente de de, ocorre apenas in situ:

(94) quatro besteyros que abastaram pera laa (CPM/p.483,1985)

(95) foy o comde comtra laa (CPM/p.360,1382)

Esses resultados dão indício de que no caso de LocPs, o tipo de preposição que os encabeça atua como elemento condicionador do movimento.

Na seqüência, apresentamos o estudo dos Casos desempenhados pelas Preposições dos PPs e dos LocPs.

\subsubsection{O Caso desempenhado pela preposição e o movimento de PPs e LocPs}

Em continuidade, identificamos os $\operatorname{Casos}^{79}$ marcados pelos PPs e LocPs ${ }^{80}$.

Encontramos PPs dativos, genitivos e ablativos; já os LocPs não aparecem como dativos e genitivos, mas apenas como ablativos. Dividimos os PPs e LocPs ablativos em dois grupos: (i) os ablativos do tipo 1, os quais estamos chamando simplesmente de ablativos, que desempenham a função de adjuntos adverbiais, função típica dos sintagmas oblíquos, e (ii) os ablativos do tipo 2, foco de nossa pesquisa, que chamamos de locativos e partitivos. Abaixo,

\footnotetext{
${ }^{79}$ Estamos grafando os Casos abstratos coma letra inicial maiúscula para que não se confunda Caso abstrato com o substantivo caso como no exemplo: "Este é um caso de redobro associado".

${ }^{80}$ Embora o conjunto de dados tenha levado à denominação de pronomes locativos preposicionados, o que reduziria todos exclusivamente ao caso locativo (ex.96), encontramos combinações de preposições com locativos, que geraram leituras ablativas (ex.103) e, sobretudo, partitivas (ex.102), características dos LocPs que explicaremos mais adiante com o cruzamento de Caso com o tipo de preposição.
} 
exemplificamos o locativo, o partitivo, o dativo, o genitivo, e o caso ablativo dos PPs, seguidos dos LocPs nos casos locativo, partitivo e ablativo, respectivamente:

(96) ...moradores que foram desta cidade (CPM/p.190, 1386)

(97) ... e assym que vos sereis delles servido (CPM/p.195, 1498)

(98) ...que ell rrey disse ao comde dom Pedro (CPM/p.202, 1693)

(99) ...que sabem a fraqueza dos mouros (CPM, p.212, 1947)

(100) ...dezemdo que por elles nom faleceria (CPM/p.210, 1887$)$

(101) E esto acabado de dezer emcaminharam pera laa (CPM/p. 365, 1522)

(102) partyda que dally fezerom (CPM/p.422, 1899)

(103) que day a poucos dias partio da cidade (CPM/p.383, 1937)

Estamos considerando locativos os PPs que expressam lugar, sendo, portanto, adjuntos adverbiais de lugar. Entendemos que os partitivos são uma espécie de locativos, mas com uma semântica de lugar de origem, de onde, da parte de.

A tabela a seguir apresenta numericamente a distribuição casual dos PPs e LocPs: 
Tabela 10: Caso X movimento de PPs e LocPs

\begin{tabular}{|c|c|c|c|c|}
\hline & \multicolumn{2}{|l|}{$\mathbf{P P}$} & \multicolumn{2}{|c|}{ LocP } \\
\hline Caso & N. & $\%$ & $\mathrm{~N}$. & $\%$ \\
\hline \begin{tabular}{|l} 
Locativo \\
\end{tabular} & $10 / 38$ & 26,0 & $09 / 27$ & 33,0 \\
\hline \begin{tabular}{|l} 
Partitivo \\
\end{tabular} & $13 / 17$ & 76,0 & $53 / 90$ & 59,0 \\
\hline \begin{tabular}{|l|} 
Dativo \\
\end{tabular} & $14 / 61$ & 22,0 & - & - \\
\hline Genitivo & $03 / 30$ & 10,0 & - & - \\
\hline \begin{tabular}{|l} 
Ablativo \\
\end{tabular} & $27 / 38$ & 71,0 & $04 / 06$ & 67,0 \\
\hline Total & $67 / 184$ & 36,0 & $66 / 123$ & 54,0 \\
\hline
\end{tabular}

Ocupam preferencialmente a posição in situ, PPs locativos, dativos, genitivos bem como os LocPs locativos (veja os baixos percentuais de movimento). Partitivos e ablativos desempenham um perfil diferente dos primeiros, pois tendem a ocupar posição mais alta na sentença (note-se os percentuais de $76 \%$ e $71 \%$, respectivamente).

Tendo em vista a diferença observada para os Casos, realizamos o cruzamento de Caso com o tipo de preposição. Começamos com o PP que apresenta preposições mais diversificadas. Os dados acham-se na tabela abaixo: 
Tabela 11: Caso X Tipo de Preposição do PP: incidência no percentual de movimento

\begin{tabular}{|c|c|c|c|c|c|c|}
\hline & Locativo & Partitivo & Dativo & Genitivo & Ablativo & Total \\
\hline & $\mathrm{N}$ & $\mathrm{N} \quad \%$ & $\mathrm{~N}$ & $\mathrm{~N} \quad \%$ & $\mathrm{~N}$ & $\mathrm{~N}$ \\
\hline De & $-\quad-$ & $12 / 16 \quad 75,0$ & $04 / 23 \quad 21,0$ & $02 / 22 \quad 9,0$ & $19 / 69 \quad 28,0$ & $19 / 6928,0$ \\
\hline $\mathbf{A}$ & $02 / 03 \quad 67,0$ & $-\quad-$ & $06 / 19 \quad 32,0$ & $01 / 03 \quad 25,0$ & $13 / 30 \quad 43,0$ & $13 / 30 \quad 43,0$ \\
\hline Em & $08 / 20 \quad 40,0$ & $\begin{array}{ll}01 / 01 & 100\end{array}$ & $01 / 05 \quad 20,0$ & $-\quad-$ & $18 / 38 \quad 47,0$ & $18 / 38 \quad 47,0$ \\
\hline Outras & - & - & $03 / 14 \quad 21,0$ & - & $17 / 47 \quad 36,0$ & $17 / 47 \quad 36,0$ \\
\hline
\end{tabular}

O primeiro dado a chamar a atenção neste cruzamento de fatores é o fato de que os PPs encabeçados por de movem-se preferencialmente quando são marcados pelo caso partitivo (75\%) e ficam in situ quando são marcados pelo genitivo (apresentam apenas 9\% de movimento). Ou seja, não é todo PP encabeçado por de que move, mas apenas o de Caso partitivo.

Como esperado, o ablativo, caso que classicamente rege os oblíquos com função de adjuntos adverbiais, e o locativo são os contextos de maior mobilidade ${ }^{81}$, depois do caso partitivo. No Latim, o locativo realizava-se com preposição ablativa mais o sintagma adverbial declinado morfologicamente no caso ablativo. Talvez a isso se deva a tendência de movimento dos PPs com preposição atribuidora de Caso ablativo.

\footnotetext{
${ }^{81}$ Embora o ablativo apresente percentuais de movimento pouco abaixo dos $50 \%$, está sendo considerado como um contexto de maior mobilidade quando comparado aos demais índices percentuais que são ainda mais baixos. Vejam-se os percentuais dos Casos genitivo e dativo.
} 
Tabela 12: Caso X Tipo de Preposição do LocP

\begin{tabular}{|l|cc|cc|ll|ll|}
\hline & \multicolumn{2}{|c|}{ Locativo } & \multicolumn{2}{|l|}{ Partitivo } & \multicolumn{2}{|l|}{ Ablativo } & \multicolumn{2}{|l|}{ Total } \\
\hline & N & $\%$ & N & $\%$ & N & $\%$ & N & $\%$ \\
\hline De & $01 / 01$ & 100 & $50 / 86$ & 58,0 & $03 / 05$ & 60,0 & $54 / 92$ & 59,0 \\
\hline Outras & $08 / 26$ & 31,0 & $03 / 04$ & 75,0 & $01 / 01$ & 100 & $12 / 31$ & 39,0 \\
\hline
\end{tabular}

Os resultados da tabela acima apontam a prevalência da preposição de, com função Casual partitiva, acionando o movimento do LocP, o que confirma os achados para os PPs. O baixo índice de locativos e ablativos impede uma análise comparativa.

A seguir, cruzamos o Caso com o tipo de locativo, cujos resultados podem ser conferidos na tabela abaixo:

Tabela 13: Caso do LocP X Tipo de Locativo : percentual de incidência no movimento

\begin{tabular}{|c|c|c|c|c|}
\hline & Locativo & Partitivo & Ablativo & Total \\
\hline & $\mathrm{N}$ & $\mathrm{N}$ & $\mathrm{N}$ & $\mathrm{N}$ \\
\hline Ally & \begin{tabular}{|ll}
$07 / 13$ & 54,0
\end{tabular} & $39 / 67 \quad 58,0$ & $01 / 02 \quad 50,0$ & $47 / 82 \quad 57,0$ \\
\hline Hy & $-101 \quad-$ & $09 / 1275,0$ & $\begin{array}{ll}01 / 01 & 100\end{array}$ & $\begin{array}{ll}10 / 14 \quad 71,0\end{array}$ \\
\hline Aquy & $\begin{array}{|ll|}02 / 02 & 100\end{array}$ & $05 / 1145,0$ & $\begin{array}{ll}02 / 03 & 67,0\end{array}$ & $\begin{array}{ll}09 / 16 \quad 56,0\end{array}$ \\
\hline Laa & $\ldots / 11$ & - & I- & $\ldots$ \\
\hline
\end{tabular}

Observa-se que o movimento do LocP é favorecido quando o Caso é partitivo na presença dos locativos ally (58\%) e hy (75\%), mas não aquy (45\%).

Aparentemente, o que aciona o movimento é a anaforicidade de ally e hy e não o Caso partitivo, uma vez que aquy é não-anafórico e não move quando carrega Caso partitivo. De fato, não temos dados suficientes de Caso locativo e Caso ablativo para inferir que o Caso tenha peso relevante. Entretanto, o complemento de laa, locativo categoricamente anafórico 
(tab.7), é elucidativo a respeito da interferência do Caso no movimento dos elementos. Por ser [+ANAF], laa deveria se mover para uma posição mais alta na sentença, no entanto, todos os LocPs de Caso locativo encontram-se in situ. Deduz-se daí que o traço anaforicidade não é o bastante para acionar o movimento de LocPs e que o Caso partitivo, como registrado para ally e hy, tem forte incidência no movimento de LocPs.

Esses achados nos levaram a cruzar Caso e Anaforicidade para capturar se algum Caso é tipicamente mais anafórico que os outros. Observe os resultados da tabela abaixo:

Tabela 14: Caso X Anaforicidade do LocP : incidência no percentual de movimento

\begin{tabular}{|c|c|c|c|c|}
\hline & Locativo & Partitivo & Ablativo & Total \\
\hline & $\mathrm{N}$ & $\mathrm{N}$ & $\mathrm{N}$ & $\mathrm{N}$ \\
\hline +Anafórico & $08 / 26 \quad 31,0$ & $\begin{array}{ll}47 / 78 \quad 60,0\end{array}$ & $03 / 04 \quad 75,0$ & $58 / 108 \quad 54,0$ \\
\hline -Anafórico & $01 / 01 \quad 100$ & $06 / 12 \quad 50,0$ & $01 / 02 \quad 50,0$ & $08 / 15 \quad 53,0$ \\
\hline
\end{tabular}

O caso partitivo é o que registra maior ocorrência (78) e o que apresenta, ao lado do ablativo, alta taxa de elementos anafóricos $(60 \%)$, de onde se infere que partitivos são preponderantemente anafóricos.

Nesta seção, observamos que a preposição de é relevante para o movimento de LocPs, mas não de PPs. De favorece o movimento dos pronomes [-REF] ally e hy, mas não de aquy [+REF]. Não se registrou a associação de de e laa [-REF].

No que se refere ao Caso de PPs e LocPs, partitivos e ablativos levam ao movimento desses elementos, os demais Casos não.

Do cruzamento de Caso com tipo de Loc, observou-se que o partitivo aciona o movimento dos anafóricos ally e hy, mas não de aquy. Entretanto a anaforicidade não é traço 
suficientemente forte para acionar o movimento dos LocPs, uma vez que laa é categoricamente anafórico e ocorreu tão somente in situ. Concluímos daí que, de modo geral, o traço anaforicidade e o Caso abstrato devem se associar para promoverem o movimento de LocPs.

\subsection{Considerações finais do capítulo}

Ao longo do capítulo, observamos que PPs e Locativos apresentam distribuição diferenciada, no sentido de que os pronomes locativos tendem a mover-se na estrutura sentencial e PPs tendem a ficar in situ. Os Locativos Preposicionados, por serem ao mesmo tempo Locs e PPs, equilibram movimento e posição canônica.

Os PPs movem-se mais produtivamente sob três condições: i. devem contemplar um DP leve, ii. devem ter a função de adjunto e iii. devem ocorrer em oração adjetiva. Os locativos movem-se mais livremente: não estão condicionados à função sintática, à posição do sujeito e ao tipo de sentença encaixada. Os locativos preposicionados movem-se freqüentemente em contexto de sujeito posposto, acompanhando os PPs que apresentam leve aumento percentual nesse contexto. Em conformação com a Etapa C proposta por Moraes Castilho (2005), os PPs argumentais tendem a permanecer in situ. Ressalte-se, porém, que os PPs adjuntos, como acabamos de afirmar, movem-se mais expressivamente que os argumentais. Esses fatos se coadunam com a característica referencial dos PPs. Por serem expressões-R (referenciais por excelência, ou seja, não precisam de um antecedente), podem ocupar posições variadas na $\mathrm{S}$, sob restrição apenas da função sintática que exercem. Diferente é o caso dos locativos. Por serem pronomes, e, em grande parte dos casos, anafóricos, tendem a ocupar posições mais fixas na $S$, a saber, posições mais altas. Isto se dá quando o Loc apresenta traços anafóricos, independentemente de restrições advindas da função sintática de argumento ou de adjunto que assumem na sentença. 
De fato, o traço anaforicidade do locativo se sobressaiu como fator condicionante do movimento seja de locativos puros seja de locativos preposicionados. As formas ally e hy foram as que mais apresentaram mobilidade. A justificativa para esse movimento parece estar no caráter essencialmente anafórico de hy, como salientam Mattos e Silva (1989), Muidine (2000) e Moraes Castilho (2005). Além disso, é possível que formas pronominais anafóricas movam-se para estarem mais próximas de seu antecedente.

De modo geral, temos pronomes locativos movidos de um lado, e de outro, PPs de Caso locativo in situ. Uma das explicações plausíveis está no fato de que pronomes e sintagmas mais complexos apresentam pesos diferentes. Dentro da proposta da tripartição pronominal (Cardinaletti \& Starke 1999), os anafóricos hi e ende são considerados pronomes $\underline{\text { fracos }}$ (Muidine, 2000). Assumimos que esses pronomes (e outros como ally, laa), presos semanticamente ao antecedente, são levados a mover-se. Diferentemente, os PPs, enquanto sintagmas preposicionados são uma forma forte, e também mais pesada, e por terem já em si a referência semântica não necessitam se aproximar de um suposto antecedente, permanecendo, portanto, in situ. Verificamos que, primordialmente os PPs leves é que sofrem movimento.

Tendo por pressuposto a substituição do pronome fraco hi pelos sintagmas preposicionados, pode-se inferir que formas leves são substituídas por outras mais pesadas e/ou que formas mais suscetíveis a se mover para as camadas mais altas da sentença, são substituídas por outras com maior diversidade de posições. De fato, o pronome $h i$, uma forma fraca, dependia de um suporte fonológico e semântico, o que favorecia seu movimento. Ao ganhar a forma aí, o pronome torna-se uma forma forte, dêitica, e, portanto, [+REF], não necessitando aproximar-se de seu antecedente no discurso através de movimento para os níveis mais altos na sentença. Formas $[+\mathrm{REF}]$ como aí, aqui, bem como os próprios PPs, são mais fortes, mais autônomas, mais independentes fonologicamente e, por isso, "passeiam" 
livremente pela sentença, ocupando posições freqüentemente mais diversificadas e, geralmente, mais baixas.

Quanto ao Caso atribuído pela preposição, o partitivo e o ablativo foram os que mais favoreceram o movimento de PPs e de LocPs. Ainda que o partitivo e o genitivo sejam Casos atribuídos pela preposição $d e$, apenas o primeiro apresentou movimento, em consonância com o tipo de categoria selecionadora de PPs e LocPs: o verbo como categoria selecionadora favorece mais o movimento do que o nome. Quanto aos ablativos, podemos inferir que se movem mais porque geralmente são adjuntos e adjuntos movem-se.

Enfim, este capítulo mostrou diferenças significativas quanto à possibilidade de movimento de PPs, locativos e locativos preposicionados e apontou os fatores condicionadores da subida desses elementos na estrutura sentencial. A questão, a discutir agora, é: qual o local de pouso desses elementos? Pretendemos responder à questão no próximo capítulo. 


\section{ANEXOS}

\section{ANEXO1: Posição dos Locativos, PPs e LocPs}

\begin{tabular}{|l|cc|cc|c|}
\hline & \multicolumn{2}{|c|}{ Movido } & \multicolumn{2}{|c|}{ In situ } & Total \\
\hline & N. & $\%$ & N. & $\%$ & N. \\
\hline PPs & 67 & 36,0 & 117 & 64,0 & 184 \\
\hline Loc & 159 & 86,0 & 25 & 14,0 & 184 \\
\hline LocP & 66 & 54,0 & 57 & 46,0 & 123 \\
\hline
\end{tabular}

ANEXO 2: Tipo de Sentença x Movimento PPs/Loc/LocPs

\begin{tabular}{|l|cc|cc|cc|}
\hline & \multicolumn{2}{|c|}{ PP } & \multicolumn{2}{c|}{ Loc } & \multicolumn{2}{|c|}{ LocP $^{82}$} \\
\hline Tipo de S & N. & $\%$ & N. & $\%$ & N. & $\%$ \\
\hline Adjetiva & $40 / 88$ & 45,0 & $98 / 106$ & 92,0 & $08 / 11$ & 72,0 \\
\hline Adverbial & $13 / 52$ & 25,0 & $35 / 44$ & 79,0 & $16 / 28$ & 57,0 \\
\hline Completiva & $14 / 44$ & 31,0 & $26 / 34$ & 76,0 & $09 / 23$ & 40,0 \\
\hline Total & $67 / 184$ & 36,0 & $159 / 184$ & 86,0 & $33 / 62$ & 53,2 \\
\hline
\end{tabular}

${ }^{82}$ Devido à baixa ocorrência de LocP, recuperamos dados de encaixadas e de sentenças independentes. Nesta tabela, porém, incluímos apenas os dados das encaixadas, daí o total de 62 dados. Nas independentes, o movimento dos LocPs atinge o índice de 57 pontos percentuais, resultado que se aproxima do contexto das adverbiais. 
ANEXO 3: Tipo de preposição X percentual de Movimento de PP

\begin{tabular}{|l|cc|}
\hline & \multicolumn{2}{|c|}{ PP } \\
\hline Preposição & N. & \\
\hline De & & \\
\hline A & $19 / 69$ & 28,0 \\
\hline Em & $13 / 30$ & 43,0 \\
\hline Outras & $18 / 38$ & 47,0 \\
\hline Total & $17 / 47$ & 36,0 \\
\hline & & \\
\hline
\end{tabular}




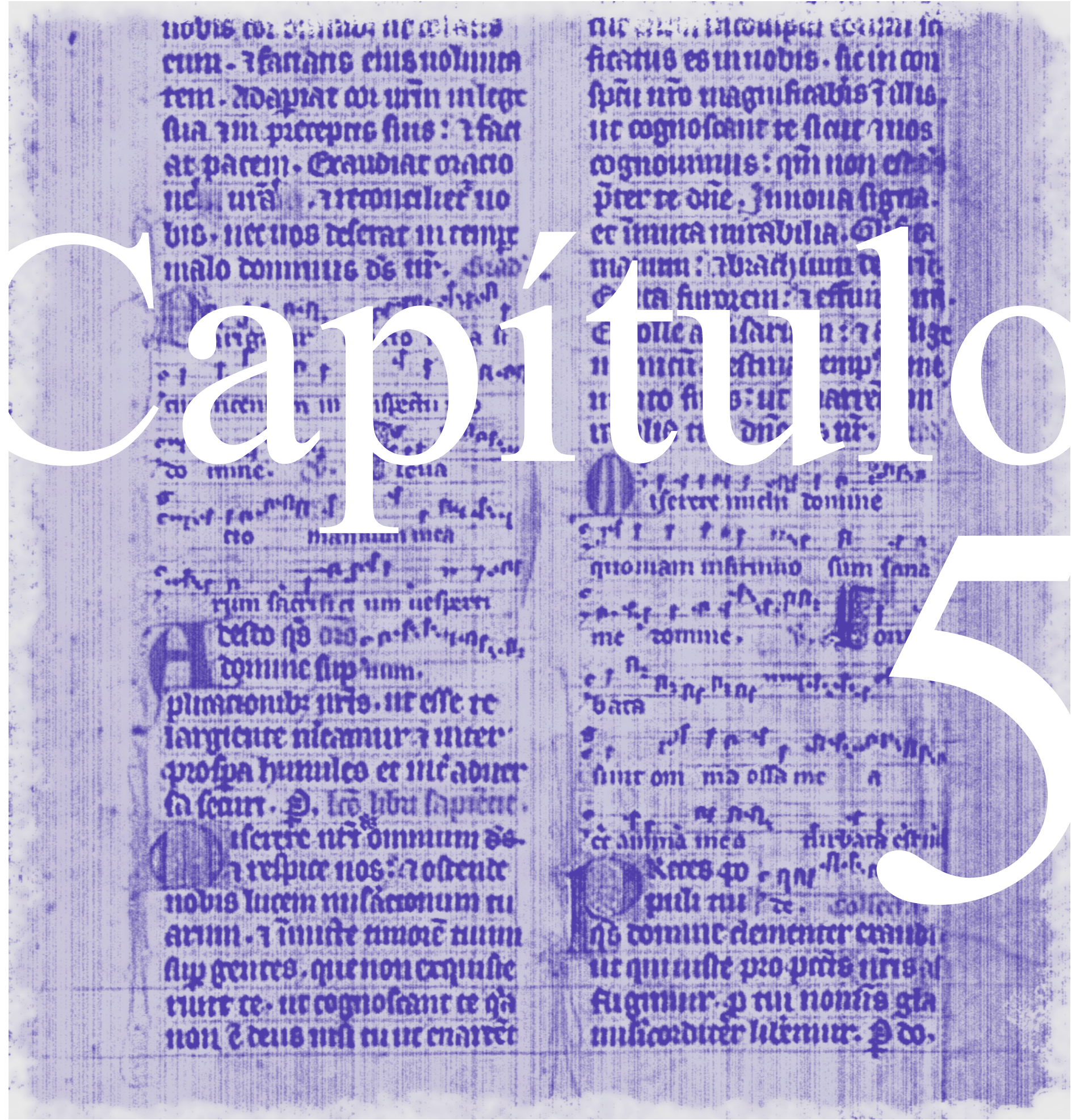




\section{O LUGAR DE POUSO DE ELEMENTOS MOVIDOS}

\section{Reposicionando os elementos na estrutura sentencial}

$\mathrm{N}$

este capítulo trataremos do local de pouso para PPs, Locativos e LocPs movidos. Trataremos, portanto, da representação estrutural da sentença, tomando por base os elementos em estudo. Em primeiro lugar, discutiremos a posição dos elementos com base na proposta de Martins (1994), tendo em mira a presença de clíticos e, em seguida, passaremos à representação estrutural, com base em Rizzi (1997) e Belletti (2002).

\subsection{O clítico como evidência do lugar de pouso}

Martins (1994) assume que o clítico marca a fronteira entre constituintes topicalizados ou focalizados e constituintes interpolados (X). Em razão desse pressuposto, passamos, a seguir, a analisar o lugar de pouso dos PPs, locativos e LocPs em função da posição dos clíticos.

Martins (op.cit.) propõe a seguinte estrutura sentencial: 
Configuração sentencial 1

Comp - Tópico (ou adjunto frásico) - foco - clítico - XPs interpolados -verbo XP

1

2

3

Tendo essa estrutura como orientação, o locativo e o LocP poderiam ser encontrados em três posições:

(i) entre o complementador e o clítico, sendo definido como tópico, foco ou adjunto frásico;

(ii) entre o clítico e o verbo, constituindo-se um XP interpolado;

(iii) à direita do verbo.

Encontramos um único caso de locativo, 03 casos de LocPs e um caso de PP entre o complementador e o clítico; ou seja, na posição 1:

(1) Ca hy lhe ficara despois fazer aquelle mesmo dano (CPM/p.239,1 590)

(2) dezer-lhe ....que por ally o faria hyr a lugar.. (CPM/p.594,1 340)

(3) que daquy $\widetilde{\mathrm{e}}$ diãte vos proverey que... (CPM/p.203,1 720)

(4) que por nenhua guisa o fezesse (CPM/p.198,1 570)

Ressalte-se que o PP que precede o clítico não tem função locativa.

$\mathrm{Na}$ posição entre clítico e verbo, que caracteriza, conforme Martins, um XP interpolado, identificamos 08 ocorrências de locativos (5-12), duas de LocPs (13-14) e 06 de PPs (15-20). Observe-se, porém, que o complemento da preposição, nos casos de PPs, é sempre uma forma pronominal (esto, ello, ella), formando um sintagma leve: 
(5) gemte que se hy aloja (CPM/p.276,1 679)

(6) que vos aquy de presente fiz juntar (CPM/p.187,1 330)

(7) se hos hii avia (CPM/p.240,1 614)

(8) como nos hy semtir (CPM/p.661,1 7660)

(9) como nos hy semtir logo (CPM/p.661,1 774)

(10) se nos aquy tornássemos (CPM/p.688,1 413)

(11) se vos laa mandais (CPM/p.700,1 688)

(12) ca todos averiam rrazão de vos aquy servir (CPM/p.194,1 480)

(13) que se todos dally partyrã (CPM/p.313,1 272)

(14) porque não avia mais de um dia que se dally partirão (CPM/p.364,1 491)

(15) daquelles que vos em esto ouvessem de servir (CPM/p.191,1 399)

(16) o nojo que se vos dello syguiyria (CPM/p.)

(17) quem vos nesto aja de servir (CPM/p.199,1 599)

(18) quanto vos a ello movestes com melhor vomtade (CPM/p.203,1 702)

(19) que vos della aveis de ter (CPM/p.205,1 760)

(20) quamdo se delles espediam (CPM/p.211,1 914)

$\mathrm{Na}$ terceira posição da estrutura sentencial, à direita do verbo, também foram identificados locativos (21-25), LocPs (26-28) e PPs (29-33):

(21) que os deyxasse ally (CPM/p.198,1 587)

(22) comsyderando que eu nom vos lexo aquy (CPM/p.206,1 780)

(23) porque minha vomtade he nõ ssomente vos ter aquy (CPM/p.261,1 294)

(24) ora vede se os avera hy (CPM/p.387,1 88) 
(25) jaa sabeis que me temdes aquy (CPM/p.522,1 880)

(26) mamdou que se nõ partyssem dally de dia nẽ de noite (CPM/p.457,1340)

(27) chegou rrecado de seu capitão que se tyrasse dally (CPM/p.465,1 550)

(28) mandou [..] escudeyros seus que se fossem pera laa (CPM/p.482,1 947)

(29) que vos syrvais delle (CPM/p.199,1 599)

(30) quamdo me servirão nas outras guerras (CPM/p.208,1 846)

(31) se me bem servirdes naquesta (CPM/p.208,1 848)

(32) que os tratasse com toda homrra e favor (CPM/p.209,1 870)

(33) que se assenhorasse de suas vomtades (CPM/p.209,1 871)

No caso de orações coordenadas, o locativo e o LocP precedem o clítico (34-40), posição também disponível para PPs (41) com DP leve, conforme os exemplos abaixo:

(34) e ally se espidio de todos (CPM/p.209, 1 866)

(35) e ally se começavam de nembrar (CPM/p.225, 1247)

(36) e ally se llamçavam sobre os momtes de palha (CPM/p.224, 1243$)$

(37) E daquy $\widetilde{e}_{\text {diante }}$ vos proverey (CPM/p.203,1719)

(38) E dally se tornarã pêra suas casas (CPM/p.382,1931)

(39) E de hy se tornarão aas fustas (CPM/p.432,1100)

(40) E dally se torarão ao caminho (CPM/p.613,1813)

(41) e por ello se ajuntarão (CPM/p.207,169)

De modo geral, nas coordenadas Loc, LocP e PP precedem os clíticos; nas subordinadas, são mais freqüentes os casos em que o clítico precede esses elementos em contigüidade ou não. A ausência de Locs interpolados em sentenças coordenadas está em 
conformidade com os resultados das pesquisas realizadas por Martins (1994), Ribeiro (1995), Namiut (2008), segundo as quais a interpolação é somente atestada em sentenças encaixadas.

Da análise da presença dos clíticos, obtivemos as seguintes posições possíveis para locativos, locativos preposicionados e PPs nas encaixadas:
(a) Comp X cl V
$\rightarrow \mathrm{X}=\mathrm{Loc}$, LocP e PP
(b) Comp cl X V
$\rightarrow \mathrm{X}=$ Loc, LocP e PP (DP leve)
(c) Comp cl V X
$\rightarrow \mathrm{X}=$ Loc, LocP e PP

Ainda que todas as posições estejam disponíveis para todas as formas (Loc, LocP e PP), a posição 1, em que o Loc/LocP/PP está na órbita de CP, é a menos produtiva. A posição 2, que representa o XP interpolado, é produtiva para Loc, LocP e PPs pronominais (DP leve) e a posição 3, posposta ao verbo, é produtiva para todas as formas.

Com relação à posição 3, há que se estabelecer se é a posição canônica (in situ) ou se haveria uma posição mais alta na sentença para hospedar o elemento movido. Observe-se as seguintes ocorrências, em que se tem um grupo verbal:

(42) que nunca se acertou passar por ally nenhu homem (CPM/p.344,1 13)

(43) que lhe os mouros nunca am-de sayr da porta ${ }^{83}$ (CPM/p.197,1 542)

(44) e assy que vos sereis delles servido (CPM/p.198,1 576)

(45) que os leixasse laa hir (CPM/p.275,1 661)

(46) porque os de Cavallo nom lhe poderia ally fazer ta gramde ajuda (CPM/p.283,1 856)

\footnotetext{
${ }^{83}$ É possível que a posposição do PP neste caso tenha sido uma forma de evitar a aliteração, caso o PP se movesse (ham de da porta sair).
} 
Em (42-43), o LocP e o PP aparecem à direita do verbo não flexionado que os seleciona, sugerindo que esses elementos ocupam a posição in situ. Entretanto, em (44-46), o locativo aparece posposto ao verbo flexionado e anteposto ao verbo que o seleciona, o que mostra que se moveu da posição canônica. Em virtude de ser resultado de movimento, mas ocupar uma posição baixa e distante do clítico chamaremos essa posição de protelada (3): Compl cl V x V $(\mathrm{x}=\mathrm{Loc} / \mathrm{PP}$-DP leve), (ex.44).

Assim, a estrutura sentencial proposta por Martins deveria ser alterada para englobar o lugar de pouso abaixo de Flexão:

Configuração sentencial 2

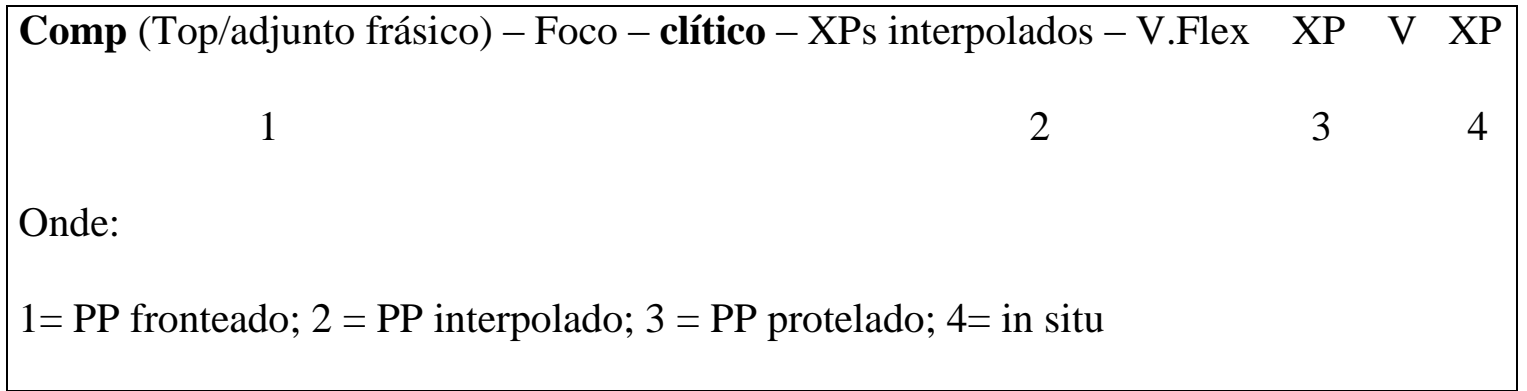

Como vimos, a evidência para a posição 3 é o grupo verbal. No caso dos verbos simples, não há como descobrir se o PP ocupa a posição protelada (3) ou in situ (4). A ambigüidade na interpretação da posição dos Loc, LocP e PP em (21-30) é reforçada pela produtividade do movimento destes elementos, como se observa no caso dos PPs interpolados. Ou seja, se o PP sobe até a posição 2 passou pela posição 3 . A não subida para 2 pode representar a permanência na posição 3, e não necessariamente na posição 4, in situ.

Retomemos as sentenças de redobro sintático para a análise do lugar de pouso do elemento redobrado. 
(47) Heram ally daquella cidade (CPM/p.233,1 439) ${ }^{84}$

(48) Ainda que aquy neste vollume achem allgũas cousas (CPM/p.185,1 271)

(49) se pervemtura haverá hy amtre vos (CPM/p.460,1 414)

(50) Que ally há nas fralldas dauquella serra (CPM/p.220/1 135)

(51) mouros que ally moravão em hũas poucas de casas (CPM/p.276,1 685)

(52) porque aquy nõ há outro capitã ũ esta terra senão elle (CPM/p.702,1740)

(53) matou hũ outro de Cavallo daquelles que ally estava na fromtaria (CPM/p.

$697,1631)$

(54) patrão que ally hera de Cartagenia (CPM/p.445,1 61)

(55) vio que dally poderia tyrar ao longo do outeiro (CPM/p.321,1 462)

(56) e dahy trouxeram a costa de lomgo ate Gibraltar (CPM/p.371, 1665)

(57) paremtes e amigos que ally de presemte eram (CPM/p.199/1618)

Observamos a ocorrência de redobro associado in situ (47-49) e de movimento de redobro associado (48). Em todos os casos de redobro dissociado, o Loc move-se para uma posição pré-verbal e o PP fica in situ. A inocorrência de clítico como marcador de fronteira, ou de sujeito pré-verbal oblitera a posição para a qual se deu o movimento: fronteado ou interpolado.

\subsection{Identificando os hospedeiros dos Loc/PPs movidos}

Nesta seção, trataremos do lugar de pouso dos elementos movidos. Para tanto, tomaremos como suporte teórico a noção da periferia externa à sentença que privilegia o desmembramento do CP, hipótese formulada por Rizzi (1997), e a periferia interna à

\footnotetext{
${ }^{84}$ Note-se que se trata de um exemplo de sentença não-encaixada, cuja motivação da inclusão se deve à raridade das construções de redobro, sobretudo de redobro associado.
} 
sentença, proposta por Belletti (2002). Em particular, adotaremos a idéia da impossibilidade de recursividade de elementos focais na mesma sentença e da realização do sujeito como elemento que marca fronteiras, além da posição do clítico, outro marcador de fronteiras, como sugere (Martins 1994), como vimos acima.

\subsubsection{O lugar de pouso do $\mathrm{Loc}^{85} / \mathrm{PP}$ fronteado e interpolado}

Tomando-se o clítico como fronteira de constituintes, chegamos a três lugares de pouso para o Loc/LocP/PP movido: fronteado, interpolado e protelado.

Nas sentenças em que o PP/Loc está fronteado, o clítico está nas cercanias do verbo flexionado. Ou seja, por ser um pronome leve, o clítico tem de se apoiar em algum suporte, adjungindo-se, portanto, a algum elemento. Conforme a literatura, no português medieval o clítico pode adjungir-se ao IP ou ao CP.

O clítico está adjungido ao IP:

(58) Ca hy lhe ficara despois fazer aquelle mesmo dano (CPM/p.239,1590)

(59) dezer-lhe ....que por ally o faria hyr a lugar.. (CPM/p.594,1340)

(60) que daquy $\widetilde{\mathrm{e}}$ diãte vos proverey que... (CPM/p.203,1720)

As sentenças acima mostram que a margem esquerda da sentença hospeda PPs e Locs. Trata-se da posição de fronteamento definida por Martins, a qual aloca constituintes com funções de tópico, foco ou adjunto frásico. Na proposta de Rizzi (1997), essa posição de fronteamento, na margem esquerda da S, pode acomodar elementos na posição de Foco ou em alguma das duas posições de Tópico. É o que se observa na representação estrutural abaixo:

\footnotetext{
${ }^{85}$ De agora em diante, quando falarmos em Loc estaremos incluindo o LocP.
} 
Representação 1: [C $\mathrm{PP} \mathrm{cl} \mathrm{V}]^{86}$

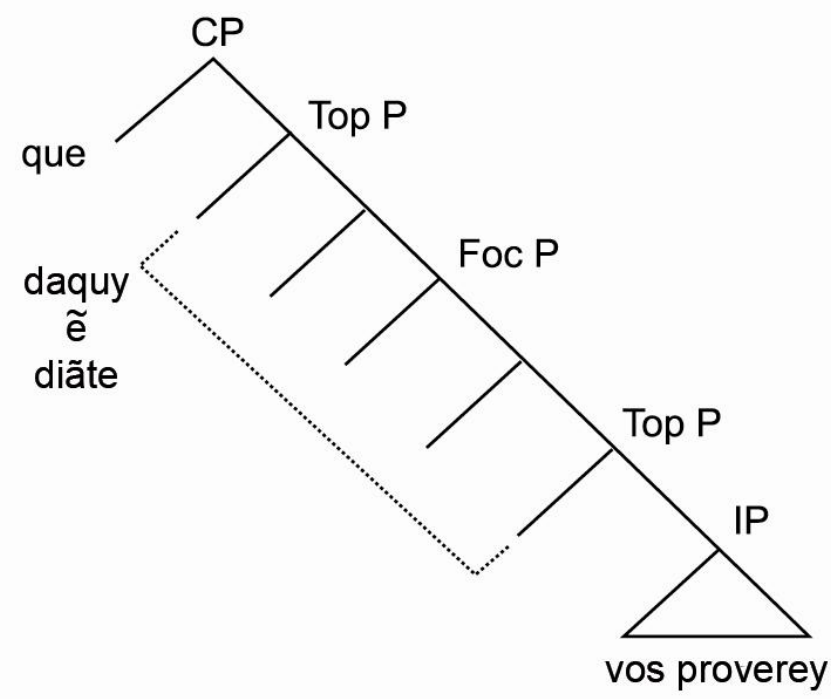

De acordo com Rizzi (op.cit.), a recursividade de focos na sentença é inviabilizada pelo tipo de informação que os focos veiculam: informação nova. Assim, nas interrogativas, o preenchimento do operador WH é incompatível com a realização de outro elemento focal na mesma sentença, uma vez que ambos encerrariam uma informação nova.

Seguindo essa linha de raciocínio, uma forma de se saber se o Loc/PP fronteado é Tópico ou Foco seria pela análise das interrogativas. Se o Loc/PP se encontrar fronteado na interrogativa WH, terá leitura de tópico, gerando, assim, uma informação nova e uma informação velha. Em todo o corpus, porém, encontramos um único caso de PP foco. Trata-se de frase interrogativa - WH, formada de uma estrutura clivada:

(61) Por tua lley_disse o comde _ que Aabu te mamda caa? (CPM, p.416, 1.722)

\footnotetext{
${ }^{86}$ Estamos representando estruturalmente apenas as categorias funcionais com suas projeções máximas, sem delimitar posições de especificador ou núcleo. O que interessa para a análise é justamente a categoria para a qual se desloca o constituinte estudado.
} 
Na sentença acima tem-se uma estrutura clivada: o PP fronteado tem leitura de foco. Entretanto, a interrogativa não é formada por WH, de forma que não destoa da proposta de Rizzi. Essa sentença nos mostra que o PP/Loc fronteado pode ter leitura focal, uma das possibilidades abertas pela proposta de desmembramento do CP. Não encontramos nenhum caso de frase interrogativa $+\mathrm{WH}$ com fronteamento de PP ou locativo, impedindo que se determine a posição dentro de CP ocupada pelo elemento fronteado.

Tomando novamente o clítico como fronteira, assumimos que pode estar adjungido a $\mathrm{CP}$, caso em que o PP/Loc movido é tido como um elemento interpolado entre clítico e verbo (Martins (1994). Martins não discorre sobre a função (tópico, foco, adjunto frásico) dos elementos interpolados. Contudo, sugere que o XP interpolado estaria à direita de Foco. Tendo em vista a inocorrência dessas duas formas na mesma sentença, PP/Loc interpolado não ocupam a posição de Foco.

Com base na estrutura proposta por Rizzi, assumimos que o PP/Loc interpolado ocorre na segunda posição de Tópico disponível na periferia esquerda. É o caso de sentenças como:

(62) gemte que se hy aloja (CPM/p.276,1 679)

(63) porque não avia mais de um dia que se dally partirão (CPM/p.364,1491)

(64) quamdo se delles espediam (CPM/p.211,1 914)

Uma evidência de que o PP/LocP interpolado ocupa a posição de Tópico abaixo de Foco está nas sentenças em que é vislumbrado o sujeito pleno:

(65) que se todos dally partyrã (CPM/p.313,1 272)

(66) Que pemsa vossa senhoria que $e u \underline{\text { de } \mathrm{m} \widetilde{\mathrm{y}}}$ posso fazer semdo hom $\widetilde{\mathrm{e}}_{\mathrm{e}}$ casy de todo ynoramte e sem nenhũa sçiemçia? (CPM/p.178/1 121) 
Assumindo que o português medieval era uma língua de sujeito nulo, o pronome forte eu só pode ocupar a posição de Tópico ou Foco (Cardinaletti \& Starke, 1999). Por outro lado, se XP interpolado ocorre à direita de Foco, como sugere Martins, só há uma posição disponível para este elemento: Tópico mais baixo.

Representação 2: [C cl PP V]

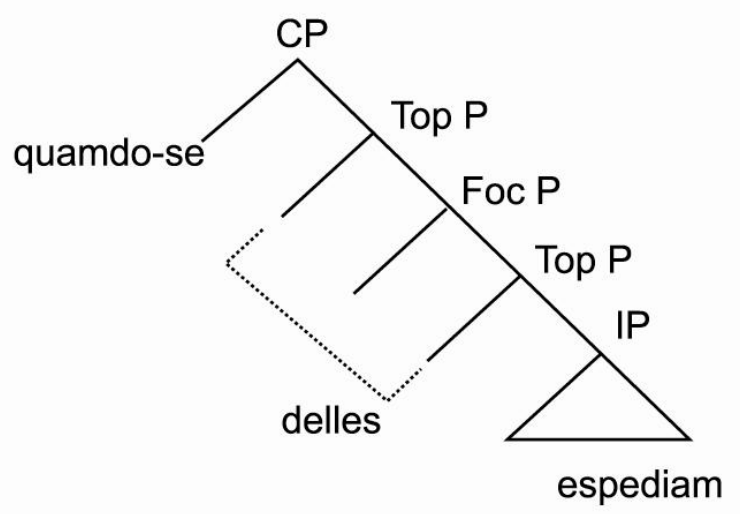

\subsubsection{O lugar de pouso do Loc/PP protelado e in situ}

O terceiro tipo de sentença em análise, em que o PP se move, mas para uma posição mais baixa, pode ser explicado estruturalmente através da proposta da posição de Tópico interna à sentença (Belletti 2002). Observe as sentenças:

(67) que os leixasse laa hir (CPM/p.275, 1661)

(68) e assy que vos sereis delles servido (CPM/p.198, 1576)

(69) porque os de cavallo nom lhe poderiã ally fazer ta gramde ajuda (CPM/p.283, 1 
A sentença (69) traz evidências de que o clítico, marcador de fronteira, se acha adjungido a IP e não a CP, pois é precedido de um DP, com função de tópico, e da categoria de negação. Quanto ao PP/Loc, observa-se que ocorre à direita do verbo flexionado, mas à esquerda do elemento que o seleciona, tendo sido, portanto, movido de sua posição canônica. Esse movimento mais baixo pode ser explicado pela proposta da margem interna à sentença, ou seja, o PP/Loc pousa em uma das posições de Tópico de IP, conforme representação estrutural:

Representação 3: [CP [IP PP V]]

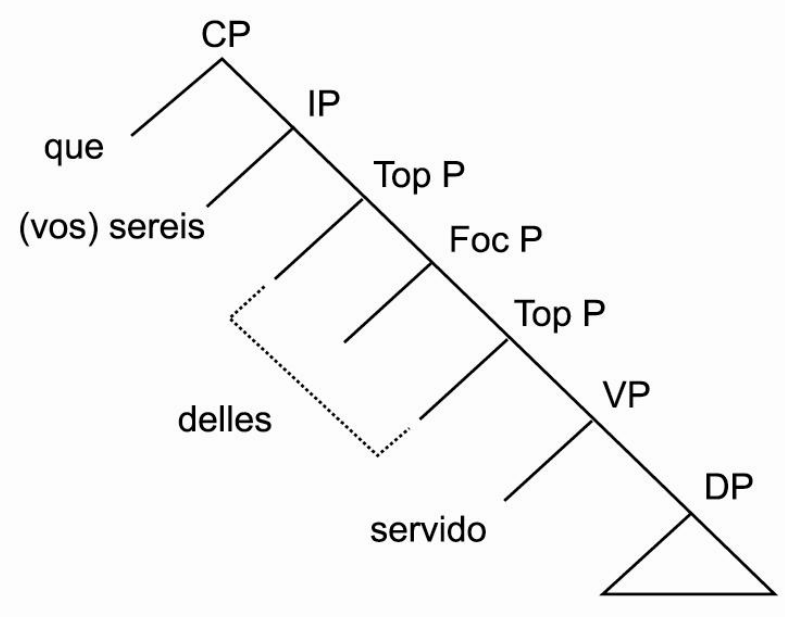

O PP/Loc protelado também foi identificado nas interrogativas $\mathrm{WH}$, confirmando a leitura de tópico. O PP pellos mouros (70) é selecionado pelo $\mathrm{N}$ perda, mas o precede. Entretanto, ocupa posição mais baixa porque não se move para a posição que precede o verbo flexionado:

(70) E quando se rrepayrará jaa pellos mouros tamanha perda? (CPM, p.429, 1. 1040) 
Em outras sentenças, o PP/Loc acha-se in situ. Declina-se, portanto, a projeção de Tópico periférica à esquerda e interna à sentença como forma de explicação estrutural. Veja que o PP está à direita do verbo que o seleciona:

(71) até que se fossem fazemdo ao seu senhorio (CPM/p.209, 1877)

(72)ate que os fezeram rretrazer naquelle pequeno rrecamto (CPM/p.217,1 63)

(73) que lhe os mouros nunca am-de sayr da porta (CPM/p.197, 1 542)

Nestas estruturas em que o PP/Loc permanece in situ, o clítico, aparentemente, pode ocupar a posição de CP ou de IP. Entretanto, o exemplo (73) traz um sujeito preenchido, entre o clítico e o verbo, sugerindo que nessas estruturas é legítima a leitura do clítico em CP. Abaixo acha-se a representação estrutural do PP in situ:

\section{Representação 4: [CP cl [(cl) IP V PP ]]}

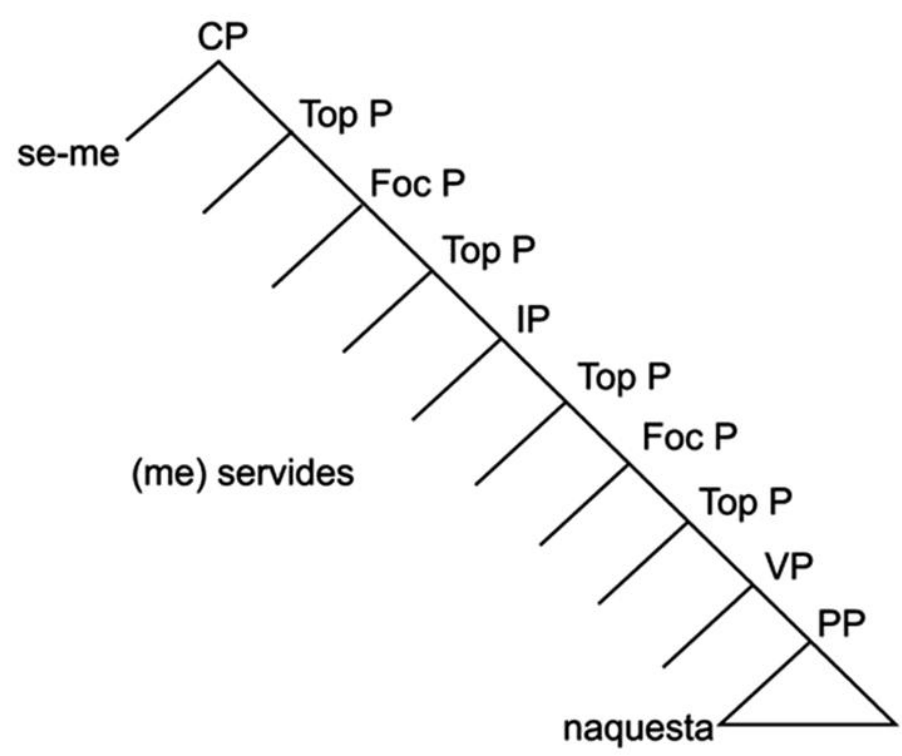


Essa estrutura é, naturalmente, compatível com interrogativas $\mathrm{WH}$, como se observa nas sentenças a seguir:

(74) Como quereis vos ysso fazer [..] se vos não trazeis liçemça pera ello? (CPM, p.439, 1260)

(75) Que serviço de Deus se podia seguir de vossa vymda [...]? (CPM/p.192, 1 441)

Além das quatro posições estudadas, foi possível identificar uma posição não mencionada pelos estudos que embasaram esta pesquisa. Observe a sentença abaixo:

(76) torres...a quall o comde dally mandara tyrar

Trata-se de uma sentença com grupo verbal e com sujeito pleno. O LocP não está in situ, pois não se acha posposto ao verbo que o seleciona. Também não se acha entre os dois verbos do grupo verbal, o que exclui a leitura de constituinte protelado. Precede o verbo flexionado, mas, por sua vez, é precedido pelo sujeito sentencial. Seguindo a proposta de Belletti (2002), segundo a qual o sujeito é marcador de fronteira para a margem interna da sentença, o LocP deve ocupar uma das posições de Tópico da periferia interna. Daremos a essa posição o nome de "interprotelada", por consistir num movimento protelado, ma em nível mais alto na sentença:

(77) se estes aquy vivessem

(78) quais aquellas fustas dally partyram 
Note-se que as sentenças encontrados para essa posição são todas exemplificações de sintagmas leves, Locs e LocPs.

Tendo em vista que a posição de XP protelado é mais baixa que a de XP interprotelado, estipulamos que o interprotelado ocupe a primeira posição de Tópico disponível na periferia interna, e o protelado ocupe a segunda posição de Tópico, preenchendo, desta maneira as posições de ancoragem desta periferia. Confira a posição do elemento interprotelado na estrutura:

\section{Representação 5: [CP [IP suj Loc V]]}

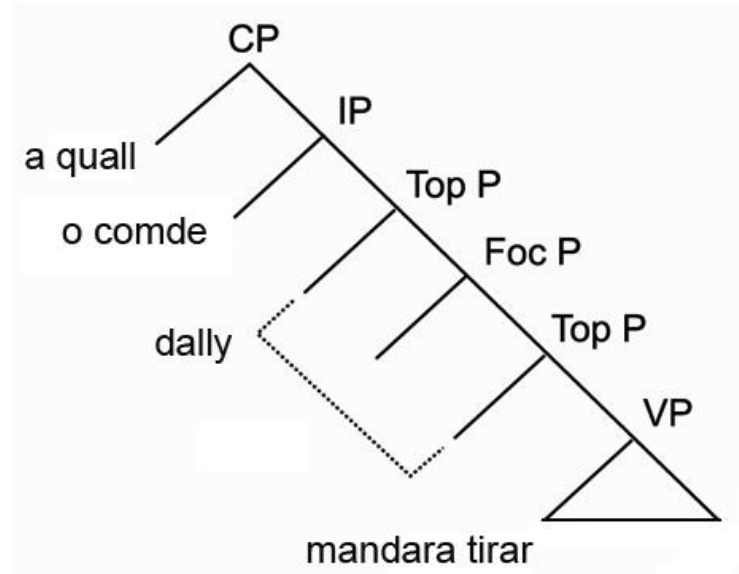

Sustentamos que, com base no clítico e no sujeito pleno como marcadores de fronteira, é possível propor as seguintes posições para Locs e PPs na estrutura sentencial do português quatrocentista, ampliando aquela proposta por Martins (1994): 
Configuração sentencial 3

Comp (Top/adj.frásico) - Foco - clítico - XPs interpolados - sujeito V.Flex XP V XP

$\begin{array}{lllll}1 & 2 & 3 & 4 & 5\end{array}$

Onde:

$1=\mathrm{PP} /$ Loc fronteado $; 2=\mathrm{PP} / \mathrm{Loc}$ interpolado $3=\mathrm{PP} /$ Loc interprotelado $; 4=\mathrm{PP} / \mathrm{Loc}$ protelado; 5= PP/Loc in situ

Essas novas posições sugerem um equilíbrio entre as periferias: há duas posições para PPs/Locs em CP e duas posições para PPs/Locs em IP. Saliente-se, porém, o caráter residual de PP/Loc1 e PP/Loc3 para cuja posição encontramos apenas as três ocorrências de Locs e LocPs acima (exs.76, 77, 78).

\subsection{Considerações finais do capítulo}

Neste capítulo, identificamos cinco lugares na estrutura sentencial que abrigam os Loc/PPs, sendo que quatro deles são resultantes do movimento desses elementos.

A posição mais alta na sentença, a que chamamos de fronteamento, hospeda Loc, LocP e PP, mas é a que apresentou a mais baixa produtividade, uma vez que excluímos do trabalho os PPs sentenciais. A segunda posição alta na sentença, interpolada entre o clítico e o verbo flexionado, se mostrou produtiva para todos os elementos, com a ressalva de que apenas o PP formado de DP leve se movimentou para esta posição. A terceira posição identificada para a hospedagem de Loc, LocP e PP é relativamente baixa na sentença, pois se acha à direita do verbo flexionado, mas acima do verbo selecionador. Por ser um movimento que se protela na sentença, chamamos o elemento que ocupa esta posição de protelado. Tratase de uma posição bastante produtiva, disponível tanto para PPs leves quanto para PPs 
pesados. Identificou-se, ainda, uma outra posição baixa, mas alta na periferia interna da sentença, a que chamamos de XP interprotelado.

Quanto à leitura e posição de Tópico ou Foco, respaldados em Rizzi (1997) e Belletti (2002), foi possível observar que o PP/Loc fronteado pode ter ambas as leituras, uma vez que identificamos uma interrogativa -WH em que o PP, em primeira posição, faz parte de uma estrutura clivada. Também encontramos uma interrogativa $+\mathrm{WH}$ com o PP fronteado. Pela impossibilidade de recursividade de elementos focais, o PP fronteado, na interrogativa $+\mathrm{WH}$ tem leitura de tópico.

A presença de sujeito pronominal precedendo o PP interpolado nos faz inferir que o PP/Loc interpolado ocupa a posição de Tópico mais baixa da periferia externa à sentença, uma vez que o português medieval era uma língua de sujeito nulo e, por conseguinte, o pronome em posição sujeito deveria ocupar a posição de Tópico, na linha de Cardinaletti \& Starke (1999).

Com base nessas reflexões e dadas as diferentes posições do clítico (o clítico se adjunge a IP no caso de fronteamento e a CP no caso de interpolação), é possível inferir que o elemento fronteado ocupa a posição de Foco ou de Tópico mais alta e que o elemento interpolado ocupa a posição de Tópico mais baixa do CP.

Quanto ao terceiro lugar de pouso para o PP/Loc movido, observamos que o clítico se adjunge a IP, como no caso do fronteamento. Esse elemento protelado é produtivo tanto nas frases declarativas quanto nas interrogativas.

Por fim, o último lugar de ancoragem registrado, Loc/LocP se encontrava entre o sujeito e o verbo ou grupo verbal. Desta forma, propusemos que esse XP esteja acima do XP protelado, configurando um movimento a que chamamos interprotelado, cujo local de pouso seria a primeira posição de Tópico da periferia interna da sentença, deixando para XP protelado a segunda posição de Tópico da periferia baixa. 


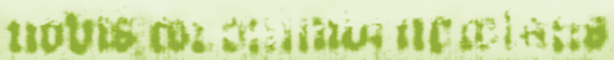

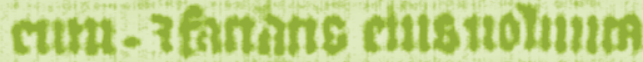
tem. rosprst ou urin mitge An zm pacterts fints : 2 firt

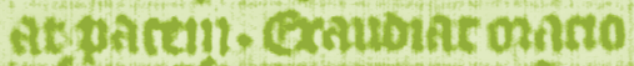

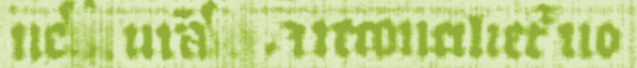

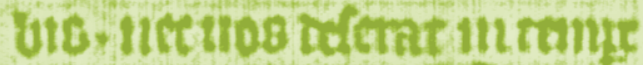
malo tomming os th. 625 :

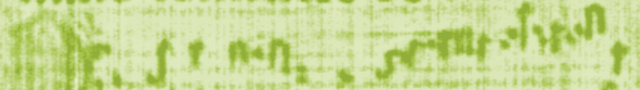

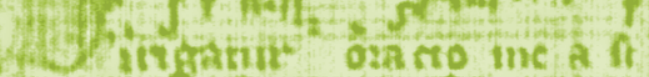

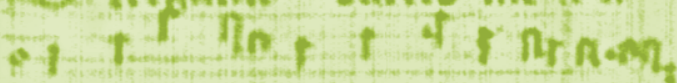
this michitim ill confleatii nio

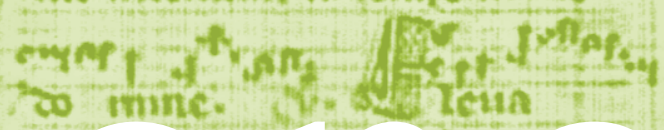
- ar wirn tat. 4 .

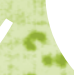
cto antest

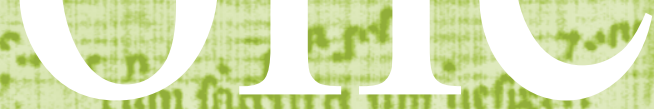

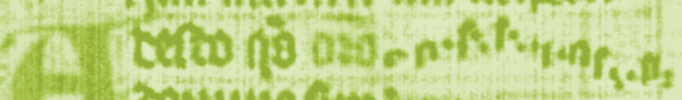
cominc fip 2 rnm.

pltminonibs stitg. Itt offe te

- Iangratre nicamurz untet.

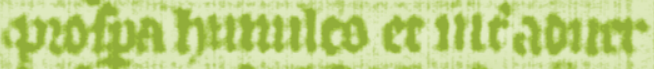
h cour.9, Iro hur Aapicut. 1. ifete tit ommmn se. 1

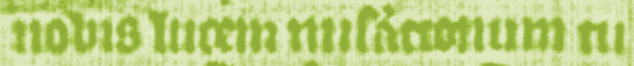
atrum - 7 Thutit tumose tutm Ays getres, quetion aptinte thit te- ne cognofant te of nou c cens unf tutre chntret

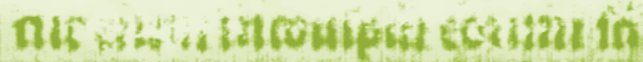
ftertus estunobis. fictum

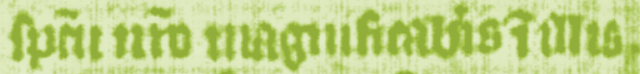
ite cognofoint te flate anos cognoumins: ntin non che?

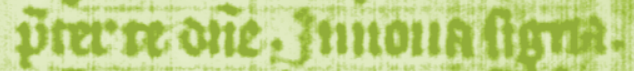
ce imtet tmitavila Gitia

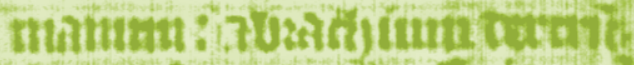

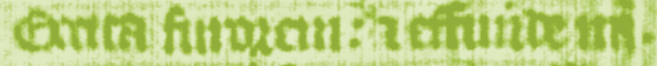
oxtolle aonntium : 7 Alitsc inimint fortin temp\% Ith mento finis: vic enatio bn tnutin tha onc os the

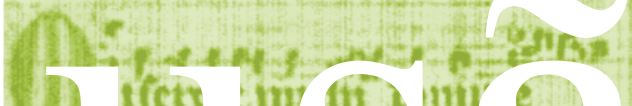

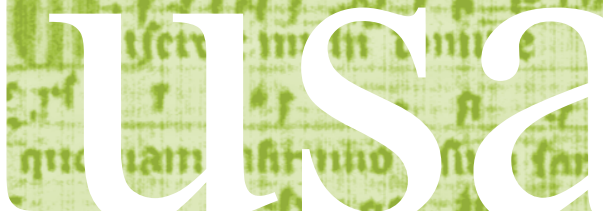

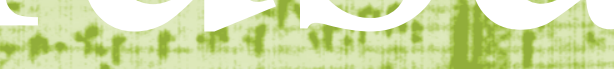
the comme, Nitsoner

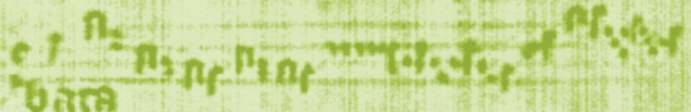

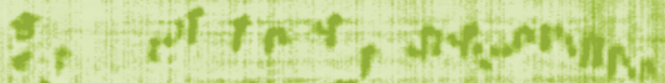
inint on ma oms me A

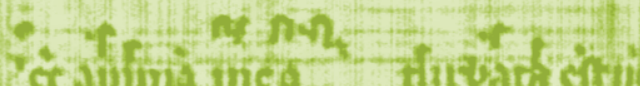
cer anma ince flitara chill

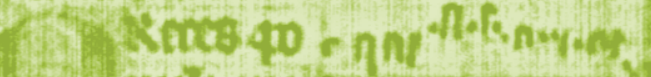

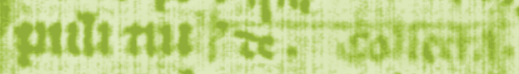
DS commedentutroming itqutate proqutouns fugumtro tuinomis gia

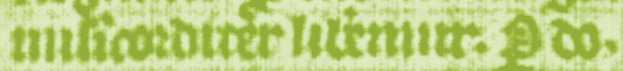




\section{CONCLUSÃO}

$\mathrm{F}$

oi o objetivo desta pesquisa estudar o movimento de PPs, Locativos e Locativos Preposicionados no português quatrocentista.

Já havíamos verificado acentuada queda no movimento dos PPs do século XIX para o XXI sugerindo um processo de variação e mudança, iniciado muito provavelmente em períodos anteriores. Baseados em trabalhos diacrônicos que apontaram para a existência desses constituintes em posições movidas em variação com a posição canônica, sobretudo no $\mathrm{PM}^{87}$, passamos a investigá-los dentro de um período tradicionalmente tido como medieval, mais especificamente no português quatrocentista.

Uma das hipóteses que regeram a pesquisa, adotada de Galves, Paixão de Souza e Namiut (2006), foi que no corpus quatrocentista transparecem variações interpretadas como competição de gramáticas na linha de Kroch $(1989,1994,2001)$. O debate instaurado em torno desse período contempla ainda outros aspectos como uma possível origem do português implantado no Brasil a partir do quatrocentista. Partindo desses pressupostos, o lugar de pouso para os PPs e Locativos movidos seria mais um fenômeno lingüístico em variação apontando para a competição de gramáticas no séc.XV.

As construções de redobro de um locativo por um PP registradas por Moraes de Castilho (2005), bem como suas etapas de dissociação contribuíram para sinalizar a posição

\footnotetext{
${ }^{87}$ Martins (1994), Ribeiro (1995), Muidine (2000), Moraes de Castilho (2005), Namiut ( 2003, 2008)
} 
de PPs e de Locs. O estudo dos Locs assumiu importante papel na pesquisa. Moraes de Castilho (op.cit.) e Muidine (2000) mostraram que o uso de Locs e de PPs concorriam na fase medieval do português, alternando entre o uso de um de outro tanto quanto o movimento e a posição canônica.

A investigação tomou como ponto de partida os casos de redobro associado e dissociado. O redobro associado se mostrou extremamente raro no corpus. A ausência do clítico como fronteira na estrutura sentencial impediu a análise do lugar de ancoragem desses elementos. A alta produtividade de interpolação de Locs e PPs poderia levar a inferir que o redobro associado movido teria passado a ocupar a posição interpolada. Entretanto, tendo em vista a natureza residual do fronteado e do redobro associado, é mais plausível assumir que este ocupa a posição fronteada. Uma vez indispensável o lugar de fronteado, o redobro se fragmentou.

Todos os casos de redobro dissociado apresentaram o locativo adjacente a CP e o PP à direita do verbo. Parece que, pelo menos no caso do redobro dissociado, é possível falar em especialização de funções sintáticas, sendo que o locativo movido passa a ter função de argumento e o PP in situ a função de adjunto, em conformidade com Moraes Castilho (2005).

Nos casos em que o redobro é desfeito, estabelecendo-se a alternância entre locativo e PP, passamos a ter maior índice de movimento de Locs do que de PPs, os quais, para moverem-se, devem obedecer alguns requisitos. $\mathrm{O}$ movimento dos locativos não é condicionado por fatores lingüísticos, ao contrário do movimento dos PPs que depende do peso do DP, da função sintática e do tipo de oração. Os locativos preposicionados, por sua vez, apresentam características dos locativos e dos PPs.

Da análise do tipo de pronome locativo, pudemos observar que o traço anafórico condicionava o movimento. De fato, os pronomes locativos hy e ally, puros ou preposicionados, foram os que mais apresentaram mobilidade, justificada pelo traço anafórico 
desses elementos. Notadamente, as mudanças no sistema pronominal locativo como a perda de ende e a reanálise de $h i$ em aí, apontadas por Muidine (2000) incidiram na posição e no uso dos PPs. Os pronomes ende nem mesmo foram encontrados em nosso corpus, em contrapartida, PPs e Locativos Preposicionados com função partitiva foram largamente apurados, fato que nos levou a admitir que ende já havia sido substituído pelos PPs partitivos no documento estudado.

O tipo de preposição também se mostrou revelador quando cruzado com o Caso que atribuía ao seu complemento. O caso partitivo (que carrega semântica anafórica) e o ablativo foram os que mais favoreceram o movimento de PPs e de LocPs. Já o genitivo, atribuído pela preposição de que também atribui o partitivo não mostrou significância quanto ao movimento de PPs e LocPs.

De modo geral, a análise quantitativa mostrou uma tendência à subida de formas leves e anafóricas como os Locs e PPs leves, de um lado, e de outro a permanência in situ de PPs pesados. Nossa hipótese é a de que os pronomes locativos e PPs leves subam justamente porque precisam recuperar o sentido num discurso anterior, e seriam, a contra senso, formas mais presas, enquanto os PPs pesados, por portarem em si o sentido semântico, não necessitariam se deslocar, sendo, portanto, mais livres, e, por isso, assumiriam posições mais diversificadas na sentença, ou nem mesmo se moveriam.

Observamos quatro lugares de pouso para PPs, Locs e LocPs, que foram restritos aos contextos de sentenças encaixadas. Esses elementos podem ocupar as periferias esquerda e interna da sentença. Na periferia esquerda podem ocupar a posição mais alta, fronteando para Tópico ou Foco em CP, ou podem ocorrer interpolados entre clíticos e verbos hospedando-se na posição de Tópico mais baixa do CP. No que concerne à periferia interna, o movimento interprotelado "despeja” o PP/Loc entre o sujeito e o verbo, e o protelado aloca o PP/Loc à direita do verbo (ou entre os verbos o grupo verbal), hospedando-se na primeira e segunda 
posição de Tópico, respectivamente. Dentre os movimentos, são bastante produtivos no corpus a interpolação e protelação.

Note-se que do ponto de vista de condicionamento lingüístico, o comportamento de PPs e Locs se mostrou diferenciado, o que nos leva a inferir que nesse período dava-se início à fixação da posição desses constituintes na estrutura sentencial ${ }^{88}$. Entretanto, a análise qualitativa apontou a disponibilidade de todas as posições de pouso para Locs, LocPs e PPs, de modo a inviabilizar a afirmação categórica de uma fixação dos elementos em posições próprias.

Portanto, tomando o clítico e o sujeito como marcadores de fronteira, podemos visualizar as quatro posições de ancoragem que reproduzimos na estrutura sentencial abaixo:

\section{Configuração sentencial $1^{89}$}

Comp (Top/adj.frásico) - Foco - clítico - XPs interpolados - sujeito V.Flex XP V XP

$\begin{array}{lllll}1 & 2 & 3 & 4 & 5\end{array}$

Onde:

$1=\mathrm{PP} /$ Loc fronteado $; 2=\mathrm{PP} /$ Loc interpolado $; 3=\mathrm{PP} /$ Loc interprotelado $; 4=\mathrm{PP} /$ Loc

protelado; 5= PP/Loc in situ

\footnotetext{
${ }^{88}$ Mas fato é que, conforme observam os estudiosos de história da língua, a fixação de constituintes começa a acontecer no momento em que o Latim perde sua morfologia casual para desembocar nas línguas românicas. A morfologia dos casos e sua característica de identificar morfologicamente a função sintática dos elementos na sentença proporcionava liberdade de posições ao Latim, muito embora a posição típica fosse aquela cujos argumentos fronteavam e o verbo era final. Com a perda do sistema de Casos, os constituintes passam a se reorganizar na sentença a fim de se evitar a ambigüidade funcional. Segundo a literatura, o fronteamento de argumentos era ainda bastante comum no PM, apesar de concorrer com outros movimentos como o scrambling do objeto, ou a interpolação de constituintes de natureza diversa entre o clítico e o verbo. Nota-se que nesse momento o movimento para o meio da sentença era bastante atestado, em conformidade com as posições que encontramos.

Apesar de os argumentos movidos para o meio da sentença serem bastante atestados nos períodos medieval e início do período clássico, parece ser patente o fato de que a ordem SVO, típica do PB atual, teria começado a se delinear desde o próprio latim (Pádua, 1960:45, Parcero, 1999). Berlinck (1989) estudou a mudança da ordem dos sécs. XVIII-XX e constatou que a inversão VS caiu consideravelmnente entre esses séculos. Do Latim para o PB contemporâneo, parece ter acontecido um "rebaixamento" dos argumentos para o final da sentença, sua posição canônica, afinal.

${ }^{89}$ Essa configuração sentencial já apareceu no capítulo anterior como configuração sentencial 3.
} 
Sustentamos, desta maneira, que PP/Loc1 e PP/Loc2 ocupam a margem esquerda da sentença; PP/Loc3 e PP/Loc4 ocupam a margem interna, como se cada PP/Loc se movimentasse para uma posição de Tópico. A baixa produtividade de PP1 e PP3 sugere a competição entre as duas posições da periferia esquerda e entre as duas posições da periferia interna.

Esse percurso acompanha algumas mudanças do português sinalizadas já no período quatrocentista, como a perda do movimento de constituintes argumentais (Parcero, 1999) e a restrição de contextos de interpolação Namiut (2003, 2008), Ribeiro (1995), Paixão (2004), que vão lançar os alicerces para a configuração do português contemporâneo. 


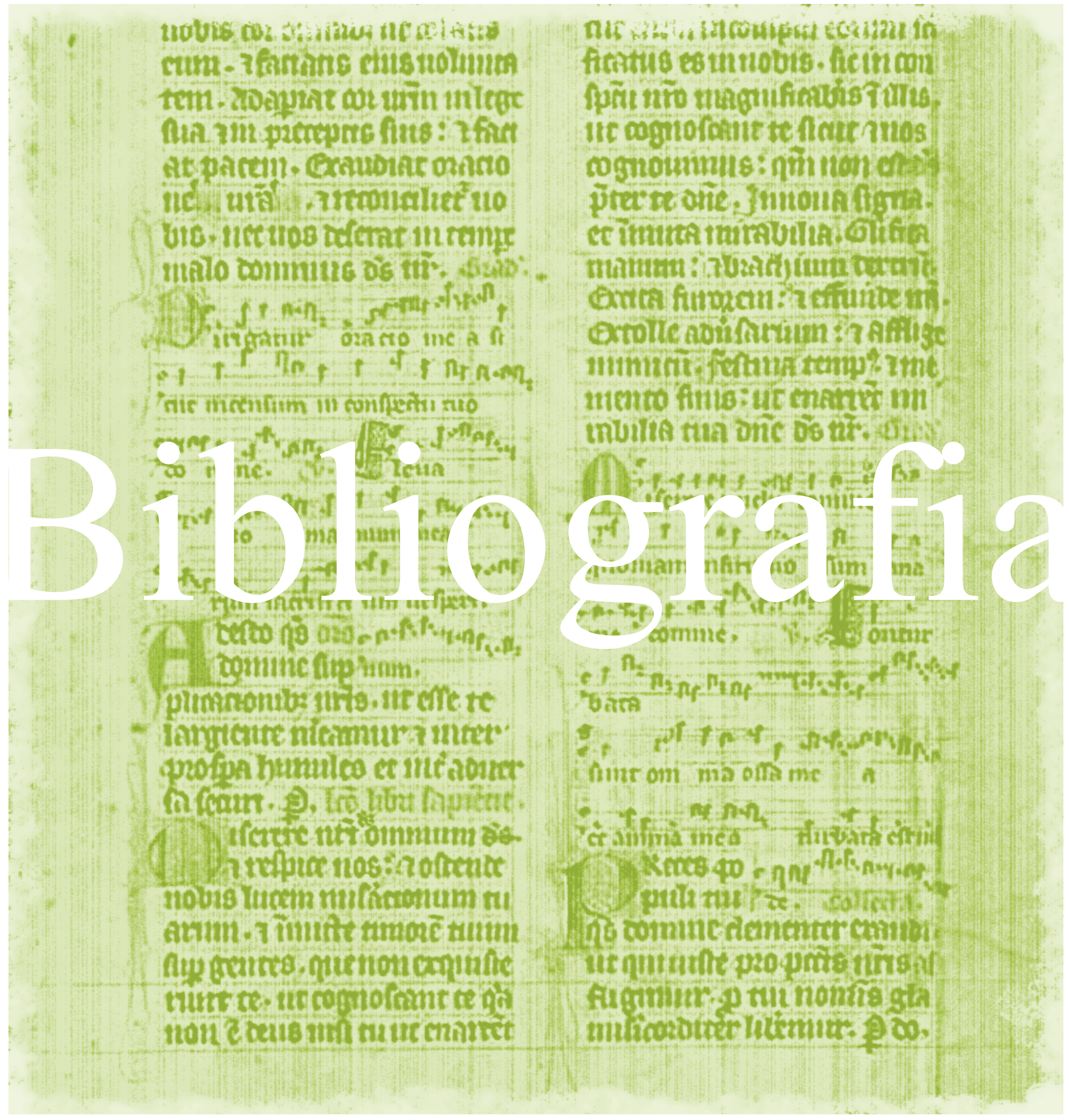




\section{REFERÊNCIAS BIBLIOGRÁFICAS}

ABNEY (1987). The english noun phrase in its sentential aspect. Tese de doutorado - MIT.

BAKER, M.C. (1988). Incorporation. A theory of grammatical function changing. Chicago: The University of Chicago Press.

BERLINCK, R. (1989). “A construção VSN no português do Brasil: uma visão diacrônica do fenômeno da ordem”. In TARALLO, F.(org.) Fotografias Sociolingüísticas. Campinas, SP: Pontes, p.95-112.

(2000). “Brazilian Portuguese VS order: a diachronic analysis”. In: KATO, M. \& E. NEGRÃO, E. (eds.) Brazilian Portuguese and the Null Subject Parameter. Vervuer: Franckfurt, p. 175-194.

BELLETTI, A. (1990). Generalized Verb Movement. Turin: Rosemberg \& Sellier.

(2002). "Aspects of the low IP area". In.: RIZZI, L. (org). The structure of IP and CP: The Cartography of Syntactic Structure. v. 2. Oxford: Oxford University Press, p.16-51.

BERLINK, R. \& GUEDES, M. (2000) E os preços eram commodos: cartas e anúncios em jornais do séc.XIX. São Paulo: Humanitas (FFLCH-USP).

BROCARDO, M.T. (1997). Crônica de Dom Pedro de Menezes, de Gomes Eanes de Zurara.Lisboa: Fundação Calouste Gulbenkian. Junta Nacional de Investigação Científica e Tecnológica.

CARDEIRA, E. (2005). Entre o português antigo e o português clássico. Lisboa: Imprensa Nacional. Casa da Moeda.

CARDINALLETTI, A. \& STARKE, M. (1999). "The tipology of Structural deficiency: A case study of the three classes of pronouns". In: HENK van RIEMSDIJK (ed.) Clitics in Languages of Europe. Mouton de Gruyter. Berlin/ New York, p.145-233.

CARDINALLETTI, A. (1999). "Pronoums in Germanic and Romance Languages: An overview". In: HENK van RIEMSDIJK (ed.) Clitics in the Languages of Europe. Mouton de Gruyter. Berlin/ New York, p. 33-82.

CASTRO, I. (1991). Curso de história da língua portuguesa. Lisboa: Universidade Aberta 
de Lisboa.

CEDERGREEN,H. \& D. SANKOFF (1974). “Variable rules: performance as a statistical reflection of competence". In: Language, 50 (2): 333-355.

CHOMSKY, N. (1970). "Remarks on nominalization". In: JACOBS, R \& ROSENBAUM P. (orgs.) Reedings in english transformational grammar. Waltham, MA, Ginn.

CHOMSKY, Noam. (1979). Principles and parameters in linguistic theory. Cambridge, Massachessetts (MA): MIT Press.

CHOMSKY, Noam. (1981). Lectures on Government and Binding. Dordrecht: Foris.

CHOMSKY, Noam. (1986). Knowledge of Language: it"s Nature, Origin and Use. New York Praeger.

(1992). "A Minimalist Program for Linguistic Theory”. MIT Working in in Linguistics, n.10. Cambridge: Massachussetts.

CHOMSKY, N. \& LASNIK, H. (1993). "The Theory of Principles and Parameters". In Jacobs,J. et alii (orgs). Syntax, an International Handbook of Contemporary Research. Walter de Gruyter, Berlin, New York.

CHOMSKY, Noam. (1995). The minimalist program. Cambridge (MA). MIT Press.

CYRINO, S. (1993). "Observações sobre a mudança diacrônica no Português do Brasil: objeto nulo e clíticos”. In: ROBERTS, I. \& KATO, M.(orgs.) Português Brasileiro: uma viagem diacrônica. Campinas: Editora da Unicamp.

FUKUI, N. \& SPEARS (1986). Specifiers na projetions. MIT Working in Linguistics, 8:128172.

GALVES, C. (2004). Padrões rítmicos , fixação de parâmetros e mudança linguística. Fase II. UNICAMP, Campinas. (Projeto de Pesquisa FAPESP)

GAlVES, C., BRITTO, H. e PAIXÃO DE SOUZA, M.C. (2005). "Clitic placement in European Portuguese: Results from the Tycho Brache corpus". In: Journal of Portuguese 
Linguistics, vol.4, n.1, Special Issue on variation and change in the Iberian languages: The Peninsula an d beyond.

GALVES, C, NAMIUT, C., PAIXÃO DE SOUZA, M. C. (2006). "Novas perspectivas para antigas questões: revisitando a periodização da língua portuguesa". In: Annete Endruschat/Rolf Kemmler/ Bárbara Schafer- Prieb (Hrsg) Grammatische Struturen dês Europaischen Portugiesisch. Turbigen: Calapinus Verlag, págs. 45-75.

GROPPI, M. (1997-1998). "Pronombres cliticos em el español de Montevideo". In: Pragmalinguistica, vols. 5-6, p.153-170.

HUBER, J. (1986). Gramática do Português Antigo. Trad. Do alemão por M. Manuela Gouveia Delille. Fundação Calouste Gulbenkian. Lisboa. 1986.

KAYNE, R. (1990) "Romance Clitics, Verb Movement and PRO". In: Linguistic Inquiry: 22:647-686. MIT

KAYNE, R. \& POLLOCK, J.Y. (1978). "Stylistic Inversion, Successive Cyclicity, and Move NP in French”. In: Linguistic Inquiry 9, p.595-621.

(2001). "New Thoughts on Stylistic Inversion". In: HULK \& POLLOCK (eds.). Subject Inversion in Romance and the Theory of Universal Grammar. New York: Oxford University Press, p. 107-162.

KATO, M. e TARALLO, F. (1989) "Harmonia transistêmica: variação intra- e interlingüística”. Preedição, 5, Campinas.

KATO, M. (1989a) O estatuto sintático e semântico da noção de tópico no português do Brasil. Campinas, Unicamp. (mimeo)

(1993) "Recontando a história das relativas em uma perspectiva paramétrica". In: ROBERTS, I. \& KATO, M. (orgs.) Português Brasileiro: uma viagem diacrônica. Campinas: Ed. Da Unicamp.

KATO, M. (1999). "Strong pronouns and weak pronominals and the null subject parameter". In: PROBUS 11 (1): 1-37. 
KROCH, Anthony. (1989) Reflexes of Grammar in Patterns of Language Change. Language Variation and Change, 1: 199-244.

(1994) "Morphosyntactic Variation". In: BEALS, K. et alii (eds.). Papers from ${\text { the } 30^{\text {th }}}$ Regional Meeting of the Chicago Linguisticis Society: Parasession on Variantion and Linguistic Teory.

KROCH, A. (2001). "Syntactic change". In : M. BALTIN \& C. COLLINS (eds.). The handbook of contemporary syntactic theory, 699-729. Oxford: Blackwell Publishers.

KROCH, A. (2003). Mudança Sintática. Disponível em: www.ling.upenn.edu/kroch. Acesso em Agosto de 2008.

LABOV, W. (1972) The Design of a Sociolinguistic Research Project. Report of the Sociolinguistic Workshop. Central Institute of Indian Languages. Mysore, India.

(1972) Sociolinguistic patterns. Philadelphia: University Philadelphia Press.

(1975) "On the use of the present to explain the past". In: Linguistics at crossroads, Liviana Editrice-Jupiter Press.

(1982) "Building on empirical foundations. In: LEHMAN \& MALKIEL (eds.): Perspectives on historical linguistics. Amsterdam/Philadelphia: John Benjamins Publishing Company.

LAKA (1990). Negation in syntax: On the nature of functional categories and projections. Cambridge, Massachussets: MIT Working Papers in Linguistic.

LAKA (1993) Negative fronting in Romance: movement to $\sum$. In: Linguistic perspectives on the romance languages. Amsterdam/Philadelphia: John Benjamins Publishing Company.

LIGHTFOOT, D. (1991) How to set parameters: arguments from language change. Cambridge: MIT Press.

LIGHTFOOT, D. (1999) The development of Language: acquisition, change, and evolution. Backwell: University of Maryland.

LOPES, R. E. V. (1999). Uma proposta minimalista para o processo de aquisição da 
linguagem: relações locais. Campinas: Tese de Doutorado - Universidade Estadual de Campinas.

MARTINS, Ana Maria (1994). Clíticos na história do português. Lisboa: Dissertação de Doutoramento em Linguiística Portuguesa- Universidade de Lisboa.

(s/d) Tipologia e mudança lingüísticas: os pronomes pessoais do português e do espanhol. Lisboa. (mimeo)

MASSAGARDI MENDES, J. (2004). O alçamento de sintagmas preposicionados no português brasileiro: século XIX. São Paulo: Dissertação de mestrado apresentadaUniversidade de São Paulo.

MATTOS e SILVA, R. V. (1989). Estruturas Trecentistas. Elementos para uma Gramática do Português Arcaico. Lisboa: Imprensa Nacional- Casa da Moeda.

MATTOS e SILVA, R. V. (1994). O Português Arcaico: Morfologia e Sintaxe. São Paulo: Contexto.

MIOTO, C. \& FIGUEIREDO SILVA, C. (1995) "Wh que = Wh é que?". In: D.E.L.T.A, n.11, vol.2:301-311.

MORAES DE CASTILHO, C. M. (2001) "Seria quatrocentista o PB implantado no Brasil?". In: MATTOS e SILVA (org.) Para a História do Português Brasileiro. Vol. 2, Tomo IPrimeiros Estudos, p.57-89.

(2005) O processo de redobramento sintático no português medieval: a formação de perífrases com estar. Campinas: Tese de Doutorado - Universidade Estadual de Campinas.

MUIDINE, S. A. (2000). Os pronomes $i$ e ende no português dos séculos XIII a XVI. Lisboa: Dissertação de Mestrado-Universidade de Lisboa.

NASCIMENTO, M. (1984) Sur la postposition du sujet dans lê portuagis du Brésil. Paris: Tese de doutorado- Université de Paris VIII, inédita.

NAMIUT (TEMPONI), C. (2003). A interpolação de constituintes no português. Campinas: Relatório de Iniciação Científica- Universidade de Campinas. 
(2006) "Um estudo sobre o fenômeno da interpolação de constituintes na história do português". In: Caderno de Estudos Lingüísticos. Campinas: UNICAMP Número 48(2). Págs: 171-194..

(2008). Aspectos da História do Português. Interpolação, negação e mudança. Campinas: Tese de Doutorado- Universidade Estadual de Campinas.

NUNES, José Joaquim (1919). Compêndio de Gramática Histórica Portuguesa (Fonética e Morfologia). Lisboa: Livr. Clássica Editora. 1975. ( $8^{a}$ edição)

OLIVEIRA, M. (1999). Frases assertivas e sua variação nas línguas românicas: o seu papel na aquisição. São Paulo: Humanitas Publicações/FFLCH-USP.

OLIVEIRA, M. (2001). "Mudança Gramatical: programa de estudos". In:. Para a História do Português Brasileiro. Vol. 2, Tomo I- Primeiros Estudos, p.39-56. São Paulo: Humanitas Publicações/FFLCH-USP.

OUAHALlA, J. (1991) Functional Categories and parametric variation. London- New York. Routledge.

PÁDUA, M; CANAES, M.P. (1960). A ordem das palavras no português arcaico; frases de verbos transitivos. Coimbra: Instituto de Estudos Românicos.

PAGOTTO, E. (1993) “Clíticos, mudança e seleção natural”. In: ROBERTS, I. \& M. KATO, M. (orgs.) Português Brasileiro: uma viagem diacrônica. Campinas: Ed. Da Unicamp, pp.185-206.

PAIXÃO DE SOUZA, M. C. (2004). Língua Barroca: sintaxe e história do português nos 1600. Campinas: Tese de Doutorado- Universidade Estadual de Campinas.

PARCERO, L. (1999). Fronteamento de constituintes no português dos séculos XV, XVI, e XVII. Salvador-BA: Dissertação de Mestrado - Universidade Federal da Bahia.

POLLOCK, J-Y. (1989) "Verb Movement, Universal Grammar, and the Structure of IP". In: Linguistic Inquiry, vol.20. no3, pp.365-424.

RAPOSO, E. (1993) “Categorias Funcionais na Gramática Gerativa”. In: D.E.L.T.A., vol.9, no.2, pp.237-274. 
(1994) Affective operators and clausal strutucture in European Portuguese and European Spanish. UCSB. Mimeo.

RIBEIRO, I. (1995). A sintaxe do português arcaico: o efeito V2. Campinas: Tese de Doutorado- Universidade Estadual de Campinas.

RIZZI, L. (1992) Early Null Subjects \& Root Null Subjects. In: GenGenP. Université de Genève, vol 0, n.1-2.

RIZZI, L. (1997) The Fine Structure of Left Periphery. In Liliane Haegman (ed.) Elements of Grammar. Kluwer Academic Publishers, pp.281-337.

ROCHA, M.A.F. (2001) Adjuntos e Adjunções em Fronteiras de Constituintes no Português do Brasil. Campinas: Tese de Doutorado- Universidade Estadual de Campinas.

ROUVERET (1992). Clitic placement, focus and the Wackernagel position in European Portuguese. Université de Paris- VIII. Mimeo.

SAID ALI, M. (1971). Gramática Histórica da Língua Portuguesa. Livraria Acadêmica. Rio de Janeiro (1971). ( $7^{\text {a } e d i c ̧ a ̃ o) . ~}$

SILVA DIAS, A. E. (1933). Sintaxe Histórica Portuguesa. Lisboa: Livraria Clássica Editora.

STOWELL, T. (1981). "Small clauses restructuring”. In: FREIDIN, R. (ed.1985). Principles and Parameters and Comparative Grammar. Cambridge, MA: MIT Press.

TARAlLO, F. (1983) Relativization Strategies in Brazilian Portuguese. Pensilvânia: Tese de Doutorado- Universidade da Pensilvânia.

TEYSSIER, P. (2004). História da Língua Portuguesa. Trad. de Celso Cunha. Lisboa: Livraria Sá da Costa.

TEYSSIER, P. (1990). "Le système des deítiques spatiaux en portugais aux XIVe, XVe et XVIe siecles". Etudes de Littérature et de Linguistic. Fundação Calouste Gulbenkian. Centro Cultural Português. Paris. 161-198.

URIAGEREKA (1992). A focus position in Western Romance. Comunicação apresentada 
no GLOW 15, Lisboa; publ. in K. Kiss(ed.) Discourse Configurational Languages. 153-175. New York: Oxford University Press.

WEINREICH, U., LABOV, W. \& M. HERZOG (1968). "Empirical Foundations for a Theory of Language Change". In LEHMANN, W.P. \& MALKIEL, Y. (eds.) Directions for Historical Linguistics. Austin: University of Texas Press. p-195.

ZANUTTINI, R. (1991). Syntatic properties of sentencial negation. A comparative study of romance languages. Pensylvania: Tese de Doutorado- Universidade da Pensilvânia. 